$1-1-1932$

\title{
Efficiency of Cooperative Livestock Shipping Associations in West Virginia
}

W.W. Armentrout

Follow this and additional works at: https://researchrepository.wvu.edu/ wv_agricultural_and_forestry_experiment_station_bulletins

\section{Digital Commons Citation}

Armentrout, W. W., "Efficiency of Cooperative Livestock Shipping Associations in West Virginia" (1932). West Virginia Agricultural and Forestry Experiment Station Bulletins. 249.

https://researchrepository.wvu.edu/wv_agricultural_and_forestry_experiment_station_bulletins/250 @ WVU. It has been accepted for inclusion in West Virginia Agricultural and Forestry Experiment Station Bulletins by an authorized administrator of The Research Repository @WVU. For more information, please contact ian.harmon@mail.wvu.edu. 
Digitized by the Internet Archive in 2010 with funding from Lyrasis Members and Sloan Foundation 


\section{Efficiency of Cooperative Livestock}

\section{Shipping Associations in West Virginia}

BY W. W. ARMENTROUT 
The Purpose of the Study

I. Description of the Conditions of Production and Marketing of Livestock in West Virginia

Physical Factors _._.

Number and Distribution of Animals _-_-_-_-_-_.

Size of Farms

Effect of the Fattening Quality of Grass on the System of
Livestock Production and Marketing

Marketing Practices of Independent Dealers -..-_-_..--_-

The Seasonal Movement of Livestock to Market

II. History of Cooperative Livestock Shipping Associations in West Virginia

Time of Organization

Reasons for Organizing Cooperative Shipping Associations -.-

Volume of Business

III. The Plan of Organization

The County Unit Plan

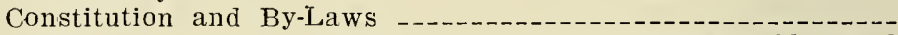

Some Provisions of Constitution and By-Laws not Observed Relation of County Association to State Association -...-.-

IV. The Aims of the Cooperative Livestock Shipping Associations in West Virginia -.......

V. The Costs of Marketing Livestock Through Cooperative Livestock Shipping Associations in West Virginia

The Cost of Marketing Sheep and Lambs

The Cost of Marketing Cattle

The Cost of Marketing Calves

Marketing Costs in West Virginia Compared with Those in

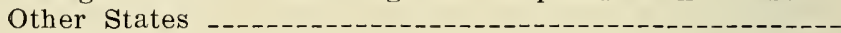

An Analysis of Transportation Costs by Associations -..-Summary on Transportation Costs _._.

Terminal Market Costs _.....

Home Expenses _.......

The Manager _.........

Methods of Prorating Expenses

Losses in Transit from Death and Cripples

Shrinkage

VI. Independent Dealers' and Cooperative Prices Compared _._-_._._._. 56

Preliminary Considerations _... 56

Methods Employed in Obtaining and Comparing Prices -...- 60

Lamb Prices _..._..._. 62

Cattle Prices -

Changes in Dealer, Cooperative, and Terminal Market Price, 1928 and 1929

VII. Summary and Conclusions _-

Marketing Cost as a Factor in Measuring Efficiency

Marketing Service as a Factor in Measuring Efficiency -..-- 87

The Terminal Market Sales Price as a Factor in Measuring Efficiency

The Effect of Cooperative Associations nn the Activities of Their Competitors as a Measure of Efficiency _........ 90

Bibliography 


\title{
The Efficiency of Cooperative Livestock Shipping Associations in West Virginia*
}

\author{
by W. W. ARMENTROUT
}

\section{The Purpose of the Study}

T

HE PURPOSE of this study is to appraise the accomplishments of cooperative shipping associations in West Virginia; to examine their efficiency as livestock marketing agencies; and to locate factors of inefficiency, the elimination of which would make such associations more effective agencies for marketing livestock, not alone in West Virginia, but also in states where similar conditions are found.

Studies of cooperative livestock shipping associations have been made by experiment station workers in several states, chiefly where livestock is concentrated in large numbers. Many important principles have been established, some of which need modification for proper application under the conditions peculiar to West Virginia, a livestock deficit area. The conditions under which livestock is produced and marketed in West Virginia are quite similar to those found in a larger area of the Appalachian region. One ontstanding difference between livestock production in this area and production in states where the most comprehensive studies of cooperative shipping associations have been made is that, while livestock production is among the chief agricultural enterprises of West Virginia, the number produced per farm is comparatively small. It seemed worth while, therefore, to study the accomplishments of cooperative livestock shipping associations in an area where the number of animals per farm is small, where the volume of business for an association is necessarily limited, and where the marketing is highly seasonal.

\section{Description of the Conditions of Production and Marketing of Livestock in West Virginia}

A knowledge of the conditions of production and marketing of livestock in West Virginia is essential to a proper appraisal of the accomplishments and for an understanding of the problems of her cooperative shipping associations.

\section{PHYSICAL FACTORS}

As a whole the state is hilly. The topography of West Virginia varies from small areas of level flood plains to larger areas of rugged mountains. It is mountainous in the eastern part, with level to roll-

* Presented in partial fulfillment of the requirements for the degree of Doctor of Philosophy at the University of Minnesota. 
ing land along many of the streams and on the tops of the hills and mountains. In general the valleys are narrow. Much of the hillside land is too steep for cultivation, but large areas are admirably adapted to pasture. Splendid grazing areas are found in the southeastern and northcentral parts of the state, where native b!uegrass grows abundantly on the limestone and shale soils. The soils of the southcentral region are somewhat less fertile, but the rough hills are also well adapted to grazing. The low sandy soils along the Ohio and Kanawha Rivers and the fertile soils of the eastern panhandle form good grain regions.

\section{NUMBER AND DISTRIBUTION OF ANIMALS}

One of the principal agricultural resources of the state is grass. Since the early settlement of the state, beef cattle and sheep have been the chief means of converting grass into human food. The hay crop alone comprises approximately 26 percent of the total crop value. While there are no extremely large producers of livestock, there are numbers of farms which graze from 20 to 50 head of mature cattle and from 50 to 75 head of sheep. On the typical farm, however, the number of animals is much smaller. The value of the beef and mutton produced in the state comprises about 12 percent of the total gross agricultural income.

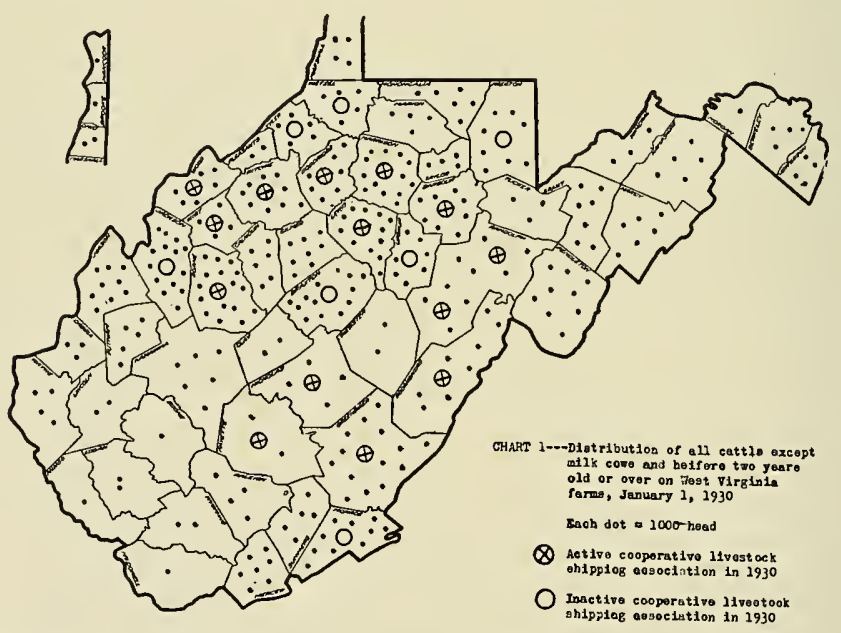

On January 1, 1930, there were 309,714 cattle other than dairy cows and heifers on farms in West Virginia.* In Chart 1 is shown the distribution of these cattle by counties. The number of cattle going to market from each county, however, is not proportionate to the distribution as shown in Chart 1 because of certain movements of cattle within the state which are explained further on.

There was a total of 531,000 of "all cattle and ca!ves" on farms

*U. S. Department of Agriculture, Crop and Livestock Estimates. 1930. 
in the state on January 1, 1930.* In Chart 2 is given their distribution by counties. Of these animals 230,000 were classed as milk cows and heifers, but many of these were of beef breeds, kept as dual purpose cows and constituting an important source of calves kept for beef production. The actual number of beef-producing animals therefore was somewhere between the number classed as "cattle other than dairy cows and heifers" and "all cattle."

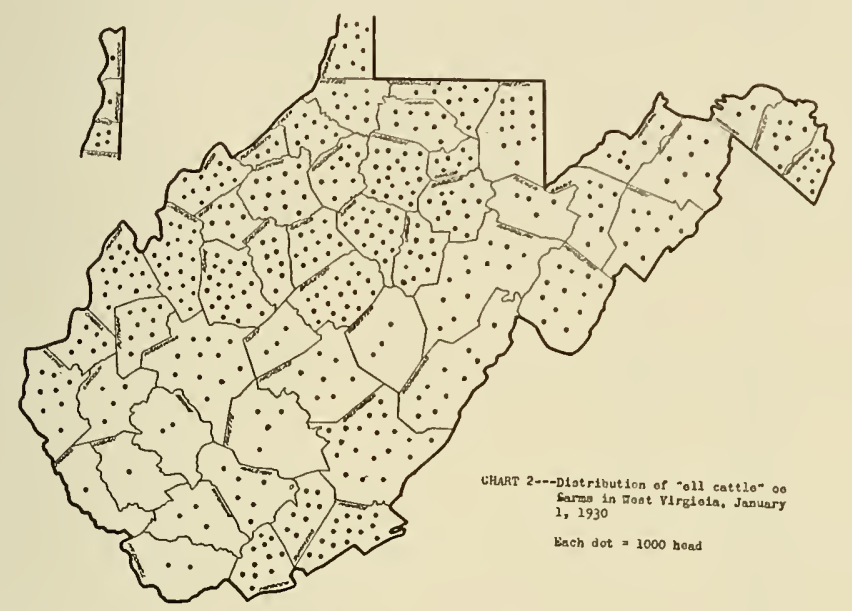

There were 629,000 sheep and lambs on West Virginia farms on January 1,1930.* Their distribution by counties is shown in Chart 3. The distribution of market lambs corresponds very closely with the distribution of sheep as shown in this chart, except in a few counties in the northwestern part of the state and in the northern panhandle, where fine-wool breeds are kept.

Charts 1 and 3 indicate that the bulk of the beef cattle is concentrated in 21 of the 55 counties, and that sheep are distributed a little more generally over the state, their production constituting a major enterprise in some 27 counties. With the exception of the areas in which fine-wool sheep are produced, the counties having the larger number of beef cattle usually are the ones having the larger number of sheep. A combination of sheep and beef cattle is the most typical livestock enterprise in the state.t

\section{SIZE OF FARMS}

A statistical picture of farms by counties as reported by the United States Census of Agriculture for 1925 is shown in Table 1.

The following facts are adapted from data in Table 1 : the average West Virginia farm is small in size; the ratio of pasture land to crop and is high; a larger percentage of the farms reported beef cattle

*U. S. Department of Agriculture, Crop and Livestock Estimates, 1930.

†The hogs produced in the state are grown largely for home consumption. Tew shipments are made to outside markets; for that reason a consideration of he marketing of hogs is omitted from this study. 
TABLE 1-Number and size of farms by counties, percentage reporting beef cattle and sheep, and average number of such animals on farms so reporting, 1925.

\begin{tabular}{|c|c|c|c|c|c|c|c|c|}
\hline County & 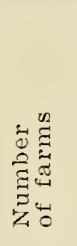 & 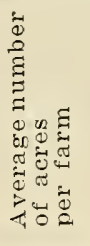 & 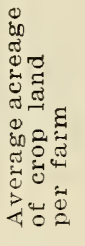 & 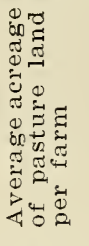 & 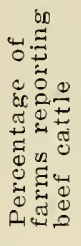 & 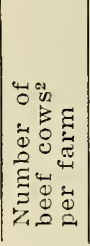 & 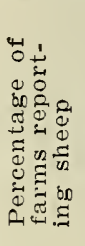 & 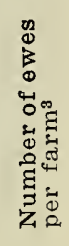 \\
\hline Barbour & 1935 & 90.1 & 19.0 & 58.9 & 63 & 2.9 & 16 & 14.5 \\
\hline Berkeley & 1436 & 107.6 & 54.0 & 28.5 & 20 & 2.9 & 11 & 23.4 \\
\hline Boone & 1066 & 68.0 & 17.3 & 18.6 & 64 & 1.4 & 3 & 7.6 \\
\hline Braxton & 2617 & 1.01 .5 & 16.5 & 48.5 & 78 & 2.8 & 26 & 16.7 \\
\hline Brooke & 364 & 115.8 & 43.3 & 50.7 & 15 & 0.8 & 19 & 57.1 \\
\hline Cabell & 2274 & 64.6 & 18.9 & 25.7 & 51 & 1.6 & 1 & 13.0 \\
\hline Calhoun & 1594 & 99.2 & 19.0 & 48.9 & 79 & 2.2 & 8 & 14.0 \\
\hline Clay & 1159 & 68.3 & 16.5 & 22.4 & 77 & 2.1 & 8 & 11.5 \\
\hline Doddridge & 1165 & 115.0 & 16.3 & 72.3 & 85 & 3.0 & 29 & 20.1 \\
\hline Fayette & 1725 & 50.5 & 17.3 & 18.2 & 38 & 1.1 & 11 & 8.5 \\
\hline Gilmer & 1544 & 125.0 & 19.6 & 62.6 & 84 & 3.5 & 22 & 18.7 \\
\hline Grant & 945 & 215.0 & 27.5 & 114.2 & 86 & 4.1 & 52 & 20.7 \\
\hline Greenbrier & 2682 & 118.7 & 21.0 & 63.7 & 72 & 2.7 & 37 & 21.5 \\
\hline Hampshire & 1766 & 179.3 & 34.3 & 58.9 & 63 & 2.5 & 29 & 16.0 \\
\hline Hancock & 360 & 101.2 & 37.1 & 47.2 & 6 & 7.9 & 8 & 28.3 \\
\hline Hardy & 1266 & $184: 3$ & 25.3 & 70.9 & 58 & 2.7 & 49 & 16.4 \\
\hline Harrison & 2108 & 84.1 & 16.7 & 55.7 & 62 & 2.7 & 15 & 21.5 \\
\hline Jackson & 2701 & 100.0 & 22.2 & 64.1 & $7 \overline{1}$ & 2.6 & 15 & 18.2 \\
\hline Jefferson & 920 & 119.8 & 68.5 & 38.3 & 29 & 1.8 & 24 & 33.4 \\
\hline Kanawha & 3691 & 57.7 & 15.7 & 26.8 & 17 & 2.1 & 1 & 21.5 \\
\hline Lewis & 1729 & 128.1 & 18.2 & 85.6 & 81 & 3.6 & 41 & 21.9 \\
\hline Lincoln & 2298 & 78.8 & 21.2 & 21.6 & 21 & 0.7 & 3 & 5.0 \\
\hline Logan & 753 & 74.5 & 13.0 & 13.0 & 74 & 1.7 & 3 & 6.3 \\
\hline McDowell & 1418 & 38.3 & 10.9 & 6.5 & 24 & 1.8 & 8 & 4.0 \\
\hline Marion & 2460 & 65.1 & 11.6 & 40.4 & 21 & 1.3 & 10 & 21.2 \\
\hline Marshall & 1681 & 102.4 & 30.4 & 53.3 & 17 & 1.3 & 35 & 38.1 \\
\hline Mason & 2455 & 100.2 & 26.5 & 56.3 & 47 & 3.1 & 8 & 16.8 \\
\hline Mercer & 2310 & 76.8 & 15.1 & 34.9 & 45 & 1.6 & 14 & 16.5 \\
\hline Mineral & 758 & 193.3 & 32.2 & 72.6 & 39 & 3.7 & 24 & 21.7 \\
\hline Mingo & 1140 & 65.7 & 12.6 & 11.2 & 25 & 0.1 & 9 & 6.8 \\
\hline Monongalia & 1835 & $\$ 2.6$ & 19.2 & 49.2 & 57 & 1.9 & 19 & 29.0 \\
\hline Monroe & 1961 & 121.1 & 22.4 & 54.0 & 84 & 2.7 & 41 & 20.8 \\
\hline Morgan & 842 & 119.3 & 37.7 & 25.1 & 66 & 2.0 & 1 & 11.2 \\
\hline Nicholas & 1574 & 86.4 & 20.2 & 30.5 & 83 & 29 & $4 \overline{1}$ & 11.9 \\
\hline Ohio & 460 & $\$ 3.6$ & 34.2 & 44.7 & 8 & 2.0 & 15 & 39.1 \\
\hline Pendleton & 1319 & 210.1 & 27.9 & 77.9 & 70 & 4.6 & 21 & 20.1 \\
\hline Pleasants & 858 & 80.7 & 18.4 & 38.9 & 37 & 1.7 & 7 & 22.9 \\
\hline Pocahontas & 1383 & 164.8 & 23.4 & 92.7 & 74 & 4.3 & 65 & 30.1 \\
\hline Preston & 2731 & 86.5 & 22.1 & 46.7 & 59 & 2.8 & 21 & 12.3 \\
\hline Putnam & 2053 & 87.2 & 24.6 & 37.8 & 49 & 1.7 & 3 & 13.1 \\
\hline Raleigh & 1708 & 71.5 & 16.1 & 27.0 & 59 & 1.9 & 12 & 9.4 \\
\hline Randolph & 1717 & 164.5 & 22.8 & 100.4 & 68 & 3.6 & 29 & 23.8 \\
\hline Ritchie & 1503 & 108.9 & 21.2 & 59.3 & 62 & 1.9 & 24 & 19.2 \\
\hline Roane & 2514 & 113.6 & 20.1 & 70.9 & 84 & 3.3 & 16 & 18.5 \\
\hline Summers & 1921 & 97.2 & 17.7 & 42.6 & 79 & 2.4 & 23 & 12.4 \\
\hline Taylor & 1055 & 73.9 & 15.0 & 45.9 & 29 & 0.1 & 11 & 16.8 \\
\hline Tucker & 763 & 137.7 & 21.3 & 57.3 & 40 & 2.9 & 25 & 16.8 \\
\hline Tyler & 1211 & 104.3 & 20.5 & 64.6 & 44 & 1.3 & 17 & 28.6 \\
\hline Upshur & 2149 & 80.3 & 14.8 & 45.3 & 68 & 2.5 & 25 & 11.7 \\
\hline Wayne & 2883 & 77.3 & 16.9 & 31.1 & 36 & 1.5 & 2 & 4.6 \\
\hline Webster & 1065 & 103.9 & 14.1 & 25.1 & 68 & 2.1 & 35 & 12.8 \\
\hline Wetzel & 1710 & 91.3 & 23.7 & 42.1 & 50 & 1.9 & 18 & 27.2 \\
\hline Wirt & 1166 & 100.6 & 22.4 & 50.2 & 49 & 3.4 & 12 & 19.0 \\
\hline Wood & 2422 & 76.6 & 19.5 & 43.7 & 47 & 3.5 & 6 & 20.7 \\
\hline Wyoming & 1257 & 85.0 & 17.9 & 31.3 & 38 & 1.4 & 18 & 6.1 \\
\hline
\end{tabular}

${ }^{1}$ United States Census of Agriculture, 1925, Part II, U. S. Department of Commerce, Bureau of The Census.

2Number of farms reporting beef cattle used as base.

3 Number of farms reporting sheep used as base. 
than sheep; the average number of beef cows per farm is small, while the average flock of ewes is of fair size. The bulk of the livestock production is on small-sized farms and from small herds and fair-sized flocks. Thirty-six percent of the farms in the state in 1925 comprised fewer than 50 acres, 65 percent fever than 100 acres, and 86 percent fewer than 175 acres. Only three comnties averaged more than four beef cows per farm, while only one county, with the exception of those producing fine-wool breeds, averaged more than 30 eves per farm. There are few carlot producers in the state. The patronage of shipping associations is therefore limited to small producers.

A large majority of the cattle move to market as mature, grassfat cattle. A few move to neighboring states and to eastern markets as feeder cattle, but most of the feecler stock is absorbed within the state. Practically all of the lambs move to market as grass-fat lambs -the large majority to out-of-state markets.

\section{EFEECT OF THE FATTENING QUALITY OF GRASS ON THE SYSTEM OF LIVESTOCK PRODUCTION AND MARKETING}

The nature and productivity of the soil, and in a smaller way topography and altitude, have played leading roles in the development of the systems of livestock production and marketing in the state. The fattening quality of the grass is determined largely by the nature and productivity of the soil. In turn, the fattening quality of the grass has a direct bearing on the systems of production and marketing which are being practiced.

Sections of the state in which the bulk of the livestock is produced may be divided into three general types. Those sections in which the grass is of such quality that mature beef steers may be finished on grass alone are designated in this publication as Type 1 ; those in which grass is an important agricultural resource, but the quantity per acre so small and the quality such that it is impossible to finish mature beef animals on grass alone, are designated as Type 3. Sections designated as Type 2 fall between these extremes and may, and for the most part do, contain some areas similar to those found in both the Type 1 and Type 3 sections. It is characteristic of the sections designated as Type 2 to have a good quantity of grass per unit of area, but of such a quality that mature animals will not fatten on it.

Without designating all counties which would fall in each type, it seems sufficient to point out that Greenbrier, Monroe, Harrison, Lewis, Barbour, and Jackson counties have large areas classed as Type 1; Nicholas, Webster, Braxton, Clay, and Randolph counties, 'arge areas classed as Type 3 ; and Doddridge, Gilmer, Calhoun, and Roane counties, large areas classed as Type 2 .

If we assume that the counties named are representative of the three types in which they have been placed, it is possible to present a 

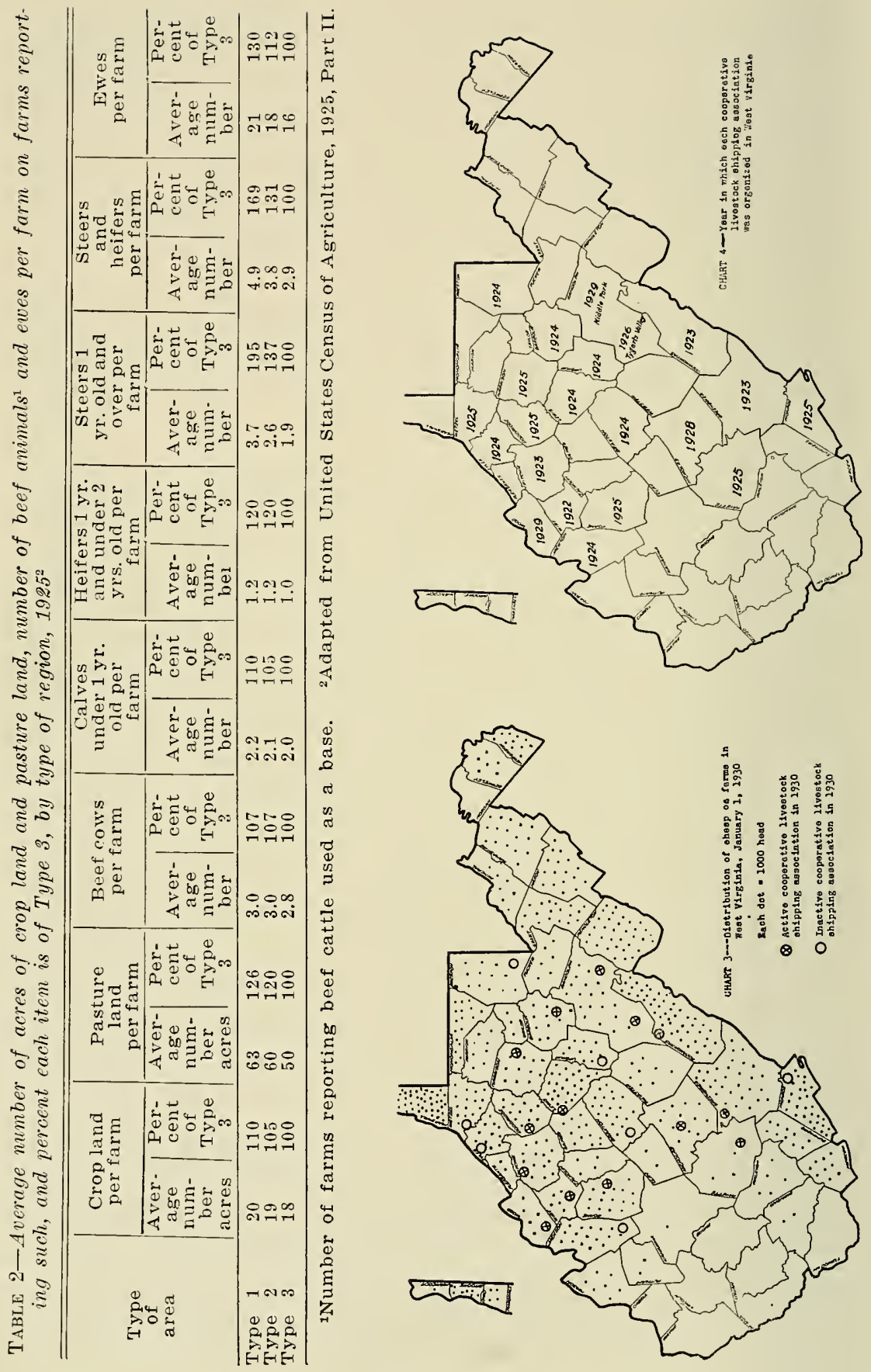
statistical picture of each type of section. From data in the United States Agricultural Census for 1925 it is found that 34 percent of all (12,000) farms in those counties placed in the Type 1 section contained fewer than 50 acres, 63 percent contained fewer than 100 acres, and 84 percent fewer than 175 acres. In the counties comprising sections designated as Type 2 , however, only 26 percent of the farms contained fewer than 50 acres, 59 percent fewer than 100 acres, and 83 percent fewer than 175 acres; but in sections designated as Type 3 , 35 percent of the farms contained fewer than 50 acres, 66 percent fewer than 100 acres, and 86 percent fever than 175 acres. There is little variation in the percentage of the different-sized farms in Types 1 and 3 , but in counties of Type 2 a smaller percentage of farms was under 50 acres.

In Table 2 the acres of crop land and pasture land and the number of various kinds of livestock per farm are shown for these counties, classified by type of section.

Large numbers of the farms in Type 3 sections are situated on very poor soils. Even the farms on the better lands do not have enough crop land to produce sufficient winter feed for as many mature cattle as their pasture would carry in the summer. Most of the small farms produce hay sufficient for their milk corvs alone, and must dispose of the calves when the pasture is gone. Consequently from the smaller and poorer farms calves are sold either as vealers or to a dealer or neighbor who is in a better position to winter them. As yearlings they may be found on the better farms. where they are carried through their second sumner and perhaps their second winter. As two-year-olds, however, they are most likely found on farms of the sections designated as Type 2, where they are wintered and pastured the next summer. They then go on to farms in Type 1 sections, where they are finished on grass as threeor four-year-olds.

It is customary for most farms in Type 1 sections to winter on ${ }^{1} y$ a part of the cattle which are pastured the next summer. It may be seen from a map of the state that counties falling in each type of section are somewhat scattered over the state; a county of one type may adjoin a county of another type. As a result the distance for moving the cattle is not great.

An analysis of the data on farms and livestock in West Virginia as found in the United States Census of Agriculture for 1925 bears out this description of the movement. Table 2, formed by combining data for those counties placed in designated types, shows that the average farm in Type 1 sections had one acre more of crop land and three acres more of pasture than the average farm in Type 2; and that the average farm in Type 2 had one acre more of crop land and ten acres more of pasture than the average farm in Type 3 .

Farms in the Type 1 area carried more beef animals* per acre of crop and pasture land than those in Types 2 and 3 , and farms in

\footnotetext{
*To arrive at an average number of beef cows, calves, heifers, and steers on farms, the number of farms reporting beef animals was used as the base.
} 
the Type 2 carried more than those in the Type 3 area. It may be observed from Table 2 that while farms in the Type 3 area were carrying slightly more cows, calves, and heifers per acre than those in the other areas, with on!y 26 percent more pasture land, farms in the Type 1 area carried 95 percent more steers, and farms in the Type 2 area with 20 percent more pasture land carried 37 percent more steers than those of the Type 3 . From these data it appears reasonable to suppose that the older beef animals moved on to the better grazing lands. No data are available concerning the number of animals which came in from other states, but the number was lnown to be small. The majority of the larger numbers per farm in Type 1 above Type 2 came from sections of Types 2 and 3 , and the larger numbers per farm in sections of Type 2 above Type 3 came mainly from sections of Type 3. Of course there are many variations from this, but the movements described are fairly typical for a large percentage of the cattle produced in the state.

\section{MARKETING PRACTICES OF INDEPENDENT DEALERS}

With such a system of production it is not surprising to find that many farmers become "cattle traders" either as a side line or as their chief activity. Purchases and sales are greatly out of proportion to the number of cattle produced. Large numbers of beef cattle change farm and owner each year from the time they are calves until they start for market. The independent dealer thrives $11 n d e r$ such conditions. Not all ship to market, many confining their activities to buying from one farmer and selling to another who desires additional cattle for wintering or pasturing. Some dealers specialize in a particular type of cattle while others purchase any sort that is offered for sale. The cooperative shipping associations have not entered this field of local marketing except in a very minor way and, therefore, offer no service to the farmer who wishes to sell or buy immature cattle. This field of marketing is left almost wholly to the independent dealer and comprises a large part of the trading in cattle within the state.

Systems of buying and selling livestock on contract which have come into common use in West Virginia further limit the volume of business available for the shipping associations. Contract buying and selling in the state takes many forms, but the most prevalent systems are the following: first, a private buyer who owns cattle sells them to a farmer for a stipulated price, agreeing to re-purchase them later at a designated time, at a price higher by from 75 cents to $\$ 2$ per hundredweight than the price at which the farmer bought them. The farmer may either winter or pasture the cattle, or he may keep them for a full year. The amount of the increase in price at which the cattle are re-purchased depends on several factors which need not be enumerated here. By this method the farmer owns the cattle, pays taxes on them, and runs the usual risks which go with ownership. His profit depends on the weight he can put on them 
and the cost by which this is accomplished. But, he has a guaranteed price, provicled the dealer with whom he contracted has sufficient funds to "take up" the cattle at the designated time.

A second practice which is in common use is for the dealer who owns cattle to "let them out" to farmers for wintering or pasturing for a specified sum per head, or per pound increase in weight. Under this system the private dealer assumes all the risk of ownership, while the farmer has a guarantee of his returns.

A third practice is for dealers to "contract" with the producer for the purchase of cattle several months in advance of the time of delivery. The "contract" is ordinarily nothing more than a verbal agreement. It is not unusual for the contract to be made a year ahead of the time of delivery, but more often it is made in the late winter or early spring for fall clelivery. It is the usual practice to contract for lambs during March and April for delivery in August and September. The earliness of contracting and the aggressiveness of the deaiers in closing contracts depend largely on their opinions of the prospective price trends. If the dealer expects a rising price trend he contracts early and is aggressive in his competition, but if he expects a falling price trend he will wait as long as possible to make contracts or possibly refuse to make them at all.

The buyer usually inspects the cattle for which he contracts, agreeing to pay a specified price at the date of delivery. In contracting for lambs, however, the buyer often does not see them when the contract is made but agrees to take all of a certain weight at a specified price. They are usually bought on the basis of two weight classifications-those weighing 60 pounds and above, and those weighing below 60 pounds. The weight classification varies somewhat with the prospective market demand and price for lambs. The seller is bound by his contract as is also, theoretically, the purchaser, but there has been considerable difficulty in the state with unreliable dealers who break contracts on a declining livestock market.

A fourth method used by the independent dealer to assure volume is to loan small sums of money as advance payments on livestock which the farmers will want to sell a few months later. Seldom does the dealer take a chattel mortgage or note, but there is an understanding that he is to buy the livestock. This method is most commonly used in the purchase of young cattle and lambs. It enables the dealer to have control over the disposal of the livestock without investing large sums of money in them or being bound by contract to purchase them at a stipulated price.

In a system of production and marketing livestock such as found in West Virginia, five factors appear to be important in their effect on the activities of cooperative livestock shipping associations. First, inclependent dealers are largely speculators in livestock. The speculation may extend over a period of two to three years when a calf or yearling is bought and title is held until it is a mature animal. Second, there is a large amount of local purchasing and selling in which the cooperative association takes no part. Third, the avail- 
able vo ume for cooperative associations is limited by the relatively small production in each county. Fourth, a large portion of the livestock in the state is controlled by the independent dealers, either through ownership, contract, or otherwise, thus further limiting the volume which is available to cooperative shipping associations. Fifth, during years of a falling market, many farmers resort to the cooperative shipping association to market their livestock when private dealers break their contracts or show little interest in buying. The effects which these factors have on cooperative shipping are shown further on.

\section{THE SEASONAL MOVEMENT OF LIVESTOCK TO MARKET}

The movement of livestock to market is highly seasonal. In 1929 approximately 50 percent of the cattle and 75 percent of the lambs were moved to market during August, September, and October. The number of carloads of cattle and calves moving from West Virginia in 1929, tabulated by counties in which the shipping points were located, is shown in Table 3 , the data for which were obtained from "station freight records" in the offices of the Baltimore and Ohio Railroad in Baltimore, Maryland; the Chesapeake and Ohio Railway in Richmond, Virginia; and the Norfolk and Western Railway in Roanoke, Virginia. The data as presented are accurate for the territories served by these railroads, except that they do not include shipments by truck, or animals driven into adjoining states. While records of the number of animals trucked to market are not readily available, it is known that the number thus transported in 1929 was small.

There are a few other railroads traversing small areas of the state from which it was not practicable to obtain records of shipments. It is estimated that by adding the number shipped over these railroads and those by truck, to the number shown in Table 3 , the total for the state would be increased by not more than 15 percent. This, however, would not change materially the picture of the seasonal movement from that shown in Table 3 . If 15 percent be added to the total shown it would make 2,359 as the total number of carloads of cattle and calves going from West Virginia to out-of-state markets in 1929. It was not possible to ascertain the number of cattle and calves separately because the records preserved by the railroads listed cattle and calves together. The largest movement in any month of 1929 was in September; however, some counties shipped more during August and some more during October than in September. In respect to seasonal movement, the movements to market during 1929 were fairly normal.

The number of carloads of cattle and calves shipped from each county as shown in Table 3 does not necessarily correspond with the number of carloads of such animals marketed from each county. The table shows the carloads summarized by counties in which the shipping points were situated. A station situated near a county line 
often draws shipments from other counties. An estimate of the maximum volume available to a county shipping association, however, may be arrived at from such a tabulation.

TABLE 3-Number of carloads of cattle and ealves loaded at shipping points within counties speeified, by months, 1929

\begin{tabular}{|c|c|c|c|c|c|c|c|c|c|c|c|c|c|}
\hline County & Jan. & Feb. & Mar.| & Apr. & Mayl & Junel & July & Aur. & Sept. & Oct. & Nov. & Dec. & Total \\
\hline Barbour & 1 & . & . & $\ldots$ & . & 2 & 5 & 45 & 13 & 15 & 10 & 4 & 95 \\
\hline Berkeley & $\ldots$ & . & . & $\ldots$ & 1 & . & . & 1 & $\ldots$ & 1 & . & $\ldots$ & 3 \\
\hline Braxton & $\ldots$ & $\ldots$ & $\ldots$ & . & $\ldots$ & 7 & 8 & 31 & 24 & 18 & 9 & $\cdots$ & 97 \\
\hline Cabell & $\ldots$ & . & .. & $\ldots$ & 3 & 6 & 10 & 6 & 7 & 5 & $\ldots$ & $\therefore$ & 37 \\
\hline Clay & . & $\ldots$ & .. & . & $\ldots$ & $\cdots$ & . & 3 & 4 & 7 & 2 & $\therefore$ & 16 \\
\hline Doddridge & 1 & $\ldots$ & . & 1 & 1 & 1 & 6 & 7 & 11 & 8 & 13 & 4 & 53 \\
\hline Greenbrier & . & $\ldots$ & 1 & 2 & 4 & 9 & 8 & 65 & 52 & 24 & 8 & 1 & 174 \\
\hline Hardy & 4 & 3 & 4 & 1 & . & 1 & $\cdots$ & 36 & 7 & 2 & 1 & 10 & 69 \\
\hline Hampshire & $\ldots$ & 2 & 1 & $\cdots$ & $\ldots$ & $\ldots$ & 1 & 4 & $\ldots$ & $\ldots$ & 3 & 1 & 12 \\
\hline Harrison & .. & 1 & $\ldots$ & 1 & 1 & ] & 11 & 69 & 75 & 38 & 44 & 5 & 246 \\
\hline Jackson & 3 & 1 & $\ldots$ & . & 5 & 9 & 11 & 27 & 56 & 47 & 13 & 2 & 176 \\
\hline Grant & $\cdots$ & 1 & 2 & 4 & 1 & $\ldots$ & 4 & 6 & 7 & 2 & 3 & 1 & 31 \\
\hline Jefferson & . & . & . & 1 & 1 & . & 10 & $\therefore$ & $\ddot{-}$ & $\dot{0}$ & $\therefore$ & 3 & $81 *$ \\
\hline Lewis & 1 & . & .. & 1 & .. & 1 & 17 & 21 & 45 & 25 & 21 & 4 & 139 \\
\hline Lincoln & $\ldots$ & $\cdots$ & . & $\cdots$ & . & . & $\cdots$ & $\cdots$ & . & 1 & . & .. & 1 \\
\hline McDowell & $\ldots$ & .. & . & $\ldots$ & . & . & . & 1 & $\cdots$ & $\because$ & $\cdots$ & $\cdots$ & 1 \\
\hline Marion & $\cdots$ & $\ldots$ & 2 & $\ldots$ & $\ldots$ & 3 & 3 & 3 & 8 & 5 & 2 & 3 & 29 \\
\hline Marshall & 2 & . & . & $\ldots$ & . & 2 & 6 & 5 & 3 & 2 & 4 & 1 & 25 \\
\hline Mason & 2 & $\cdots$ & . & $\overline{1}$ & 3 & 3 & 7 & 20 & 11 & 10 & 6 & 5 & 74 \\
\hline Mercer & $\cdots$ & $\cdots$ & . & $\cdots$ & $\cdots$ & $\cdots$ & $\cdots$ & $\ddot{i}$ & . & $\because$ & $\cdots$ & $\cdots$ & $31 *$ \\
\hline Mineral & $\ldots$ & .. & .. & .. & . & . & $\cdots$ & 1 & $\cdots$ & 1 & $\cdots$ & $\cdots$ & 2 \\
\hline Monongalia & . & .. & . & $\cdots$ & . & . & 3 & 5 & 3 & 1 & 2 & 2 & 16 \\
\hline Nicholas & $\cdots$ & $\cdots$ & $\ldots$ & 5 & $i$ & $\cdots$ & . & . & . & 2 & $\cdots$ & $\cdots$ & 8 \\
\hline Ohio & . & . & $\cdots$ & $\cdots$ & . & $\cdots$ & $\cdots$ & 3 & $\therefore$ & $\dot{\theta}$ & $\cdots$ & .. & 3 \\
\hline Pocahontas & . & $\ldots$ & 1 & $\ldots$ & . & . & 2 & 22 & 43 & 25 & 4 & . & 97 \\
\hline Preston & 2 & $\cdots$ & 3 & 8 & 6 & 2 & 7 & 6 & 5 & 12 & 5 & 2 & 58 \\
\hline Putnam & $\cdots$ & . & . & . & $\cdots$ & $\cdots$ & $\dot{9}$ & $\dot{i}$ & & 1 & $\cdots$ & 1 & 2 \\
\hline Monroe & .. & $\cdots$ & . & .. & . & 1 & 2 & 11 & 15 & 8 & 1 & . & 38 \\
\hline Randolph & . & $\cdots$ & .. & .. & . & . & . & $\ddot{i}$ & 1 & 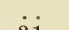 & 1 & $\because$ & 2 \\
\hline Ritchie & . & . & . & $\ldots$ & .. & 2 & 3 & 15 & 19 & 21 & 8 & 1 & 69 \\
\hline Roane & . & $\cdots$ & .. & $\ldots$ & $\ldots$ & $\ldots$ & 3 & 14 & 44 & 56 & 5 & 2 & 124 \\
\hline Summers & .. & .. & . & .. & $\ldots$ & $\ldots$ & 2 & 9 & 6 & 2 & 2 & 1 & 22 \\
\hline Taylor & $\ldots$ & . & . & $\ldots$ & .. & . & 2 & 9 & 7 & 9 & 14 & 2 & 43 \\
\hline Tyler & . & . & . & . & $\cdots$ & $\ldots$ & . & $\cdots$ & 3 & 2 & 1 & . & 6 \\
\hline Upshur & . & . & . & .. & $\cdots$ & . & . & 10 & 10 & 7 & . & . & 27 \\
\hline Wayne & .. & . & $\ldots$ & $\ldots$ & $\cdots$ & 3 & 6 & 7 & 4 & $\cdots$ & . & .. & 20 \\
\hline Webster & $\cdots$ & $\cdots$ & .. & $\ldots$ & 1 & $\cdots$ & 1 & $\cdots$ & 1 & 1 & $\because$ & . & 4 \\
\hline Wetzel & .. & 1 & . & 1 & 3 & 2 & 6 & 5 & 5 & 5 & 7 & 4 & 39 \\
\hline Wirt & . & $\ldots$ & $\ldots$ & $\ldots$ & 1 & 4 & 6 & 10 & 3 & 7 & 2 & . & 33 \\
\hline Wood & . & $\cdots$ & $\cdots$ & $\cdots$ & 1 & 4 & 6 & 10 & 11 & 14 & 1 & 2 & 49 \\
\hline Total & 16 & 9 & 14 & 32 & 33 & 63 & 156 & 489 & 503 & 384 & 195 & 61 & $2052 *$ \\
\hline
\end{tabular}

*Complete record by months not available.

The number of single and double decks of sheep and lambs moving to out-of-state markets in 1929, classified by months and by counties in which the shipping points were situated, is given in Table 4. The data were obtained in the same manner and from the same sources as were the data of shipments of cattle and calves. The same limitations therefore apply to these data as have been indicated with reference to cattle and calves. If 15 percent, the estimated deficiency in the data, be added to the totals shown in Table 4 , the number of decks of sheep and lambs marketed from the state in 1929 would be 982 single decks and 597 double decks.

Approximately 75 percent of the sheep and lambs were marketed in August, September, and October. Counties situated in the central portion of the state marketed the majority of their lambs in August, 
and those in the eastern part in September, with the exception of Pocahontas county, which supplied the bulk of the October shipments.

From Tables 3 and 4, two factors having an important effect on cooperative livestock shipping associations in West Virginia may be pointed out. The maximum volume possible for them to obtain is small, and the movement to market is highly seasonal. The manner in which these factors affect the quality of management and the efficiency of the cooperative associations is pointed out further on.

\section{History of Cooperative Livestock Shipping Assochations in WeSt Virginia}

\section{TIME OF ORGANIZATION}

The first cooperative livestock shipping association in West Virginia was organized in Wirt Connty in 1922, an outgrowth of a local lamb pool which had been operated for several years by farmers in the county. During 1923, associations were organized in Pocahontas, Greenbrier, and Ritchie connties, and in 1924 in Braxton, Lewis, Barbour, Preston, Jackson, and Tyler counties. It was also in 1924 that the county associations federated into a state association, the West Virginia Cooperative Livestock Shipping Association, Inc. During 1925 organizations were effected in Monroe, Fayette, Roane, Wetzel, Harrison, and Doddridge counties, and during 1926 in Randolph county. In 1929 an association was started in Wood county and the second one in Randolph county.

By 1929 twenty-one associations had been organized in the more important livestock producing counties of the state. Charts 1 and 3 , which give the number of beef cattle and sheep, respectively, by counties, show also the location of the active and inactive associations. It may be seen that few important livestock counties remain in which a cooperative shipping association has not been formed.

The year in which each county association was organized is shown in Chart 4 (page 8).

\section{REASONS FOR ORGANIZING COOPERATIVE SHIPPING ASSOCIATIONS}

Two principal reasons may be given for the organization of cooperative shipping associations in West Virginia: first, belief on the part of farmers that independent dealers were taking excessive margins; second, the activity of the Farm Bureau and of the University Agricultural Extension Division in promoting cooperatives. Unfortunately, records of margins which dealers obtained before the organization of cooperative associations in the state are not available. They were reported to have taken margins of as much as $\$ 3$ per cut. on lambs and $\$ 1.50$ to $\$ 2$ on cattle. Such margins were thought to be excessive. In most counties there were several independent dealers who bought livestock. This should have provided sufficient competition to have narrowed the margins, but all seemed 
to pay about the same prices and take about the same margins. If there was no conscious effort on their part to stifle competition, the result was the same since most of the smaller dealers frollowerl the prices paid by the large dealer in the community.

TABLE 4-Number of earloads of sheep and lambs loaded al slipping points within enunties specified, by single or double deck, by monlhs. 1929

\begin{tabular}{|c|c|c|c|c|c|c|c|c|c|c|c|c|c|c|c|c|c|c|c|c|c|c|}
\hline \multirow{2}{*}{ County } & \multicolumn{2}{|c|}{ Jan. } & \multicolumn{2}{|c|}{ Feb. } & \multicolumn{2}{|c|}{ May } & \multicolumn{2}{|c|}{ June } & \multicolumn{2}{|c|}{$\mathbf{J} 111 y^{r}$} & \multicolumn{2}{|c|}{ Aug. } & \multicolumn{2}{|c|}{ Sept. } & \multicolumn{2}{|c|}{ Oet. } & \multicolumn{2}{|c|}{ Nov. } & \multicolumn{2}{|c|}{ Dre. } & \multicolumn{2}{|c|}{ Total } \\
\hline & $\left|\mathbf{S}^{1}\right|$ & $\mathrm{D}^{2}$ & $\mathrm{~S}$ & $\mathrm{D}$ & $\mathrm{S}$ & D & $\mathrm{S}$ & D & $S$ & D & $S$ & D & $\mathrm{S}$ & $\mathrm{D}$ & $\mathrm{S}$ & $\mathrm{D}$ & $\mathrm{S}$ & $\mathrm{D}$ & $\mathrm{S}$ & $\mathrm{D}$ & S & $\mathrm{D}$ \\
\hline our & & $\cdots$ & $\cdots$ & $\cdots$ & $\cdots$ & . & $\cdots$ & $\cdots$ & 1 & $\cdots$ & 2 & 3 & 12 & 6 & 1 & $\cdots$ & $\cdots$ & $\cdots$ & $\cdots$ & $\cdots$ & 16 & 9 \\
\hline Berkeley & 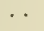 & . & $\cdots$ & $\cdots$ & $\cdots$ & $\cdots$ & $\because$ & $\cdots$ & $\because$ & : & & 3 & & & & $\cdots$ & $\cdots$ & $\cdots$ & $\cdots$ & $\cdots$ & & 3 \\
\hline Braxton & $\cdots$ & $\cdots$ & $\cdots$ & $\cdots$ & $\cdots$ & $\cdots$ & 1 & $\cdots$ & 7 & S & 12 & 21 & 3 & 14 & 3 & . & $\cdots$ & . & $\cdots$ & . & 26 & 43 \\
\hline Cabell & $\cdots$ & $\cdots$ & $\cdots$ & $\cdots$ & $\cdots$ & $\cdots$ & $\cdots$ & $\cdots$ & $\cdots$ & $\cdots$ & 2 & $\cdots$ & 1 & 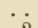 & $\cdots$ & $\cdots$ & $\cdots$ & . & $\cdots$ & . & 3 & $\cdots$ \\
\hline Clay & $\cdots$ & $\cdots$ & $\cdots$ & $\cdots$ & $\cdots$ & $\cdots$ & $\cdots$ & $\cdots$ & $\because$ & i & 2 & $\begin{array}{l}4 \\
0\end{array}$ & $\because$ & 2 & $\because$ & $\because$ & $\cdots$ & $\cdots$ & $\cdots$ & $\cdots$ & 2 & 6 \\
\hline Doddridge & $\cdots$ & $\cdots$ & $\cdots$ & $\cdots$ & $\cdots$ & $\cdots$ & $\cdots$ & $\cdots$ & 1 & 1 & 3 & 3 & 2 & 2 & 1 & 1 & $\cdots$ & $\cdots$ & $\cdots$ & $\cdots$ & $i$ & 7 \\
\hline Fayette & $\cdots$ & $\cdots$ & $\cdots$ & $\cdots$ & $\cdots$ & $\cdots$ & $\because$ & $\cdots$ & $\because 6$ & $\cdots$ & $\dot{9} \dot{5}$ & $\cdots$ & $\ddot{i}$ & $\cdots$ & 1 & $\cdots$ & $\because$ & $\cdots$ & $\cdots$ & $\cdots$ & 1 & - \\
\hline nbrier & ; & $\cdots$ & $\cdots$ & $\cdots$ & $\cdots$ & $\cdots$ & 2 & $\cdots$ & 6 & $\cdots$ & 25 & $\dot{c}$ & 43 & $\because$ & 36 & $\cdots$ & S & $\ddot{9}$ & 4 & $\cdots$ & 124 & $\because \dot{x}^{\prime}$ \\
\hline Hardy & 1 & $\cdots$ & $\cdots$ & $\cdots$ & $\cdots$ & $\cdots$ & $\cdots$ & $\cdots$ & 5 & $\cdots$ & $\because$ & 6 & • & 1 & - & $\because$ & $\cdots$ & 9 & 2 & $\cdots$ & 8 & 16 \\
\hline $\mathrm{H}$ : & $\cdots$ & $\cdots$ & $\cdots$ & $\cdots$ & $\cdots$ & $\cdots$ & $\cdots$ & $\cdots$ & $\because$ & $\because$ & 1 & $\dot{90}$ & 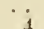 & 3 & $\cdots$ & 2 & $\cdots$ & 8 & 3 & $\cdots$ & 4 & 13 \\
\hline Har & $\cdots$ & $\cdots$ & $\cdots$ & $\cdot \cdot$ & $\cdots$ & $\cdots$ & $\dot{i}$ & $\cdots$ & 2 & 3 & 11 & 26 & 4 & 10 & $\cdots$ & $\because$ & ; & . & . & . & 17 & 39 \\
\hline Jackson & $\cdots$ & $\cdots$ & $\cdots$ & $\cdots$ & $\cdots$ & $\cdots$ & I & $\cdots$ & 4 & $\cdots$ & 5 & 5 & 7 & 6 & 4 & & 3 & $\cdots$ & $\cdots$ & $\ldots$ & 24 & 13 \\
\hline Jeffe & $\because$ & $\cdots$ & $\cdots$ & $\cdots$ & $\cdots$ & $\cdots$ & $\cdots$ & - & $\because$ & $\cdots$ & 7 & . & $\cdots$ & $\because$ & $\cdots$ & is & $\cdots$ & $\dot{i}$ & $\cdots$ & $\cdots$ & iǵ & $42 *$ \\
\hline 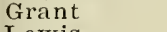 & 2 & $\cdots$ & $\cdots$ & $\cdots$ & $\cdots$ & $\cdots$ & $\cdots$ & $\cdots$ & 5 & $\because$ & 7 & $\dot{\sigma} \dot{ }$ & $\ddot{7}$ & 5 & .. & 12 & $\cdots$ & 34 & $\cdots$ & . & 12 & 54 \\
\hline Lewis & $\cdots$ & $\cdots$ & $\cdots$ & $\cdots$ & $\cdots$ & $\cdots$ & $\cdots$ & . & 3 & 7 & 16 & 53 & 7 & 14 & $\because$ & . & $\cdots$ & $\cdots$ & $\cdots$ & $\cdots$ & 26 & 74 \\
\hline Lincoln & $\cdots$ & $\cdots$ & $\cdots$ & $\cdots$ & $\because$ & $\cdots$ & . & $\cdots$ & $\cdots$ & $\cdots$ & $\cdots$ & $\cdots$ & $\cdots$ & $\cdots$ & 1 & $\cdots$ & - & $\cdots$ & $\cdots$ & $\cdots$ & 1 & . \\
\hline Mari & $\cdots$ & $\cdots$ & $\cdots$ & $\cdots$ & 1 & $\cdots$ & $\cdots$ & $\cdots$ & $\ddot{6}$ & $\cdots$ & $\because$ & $\ddot{i}$ & $\because$ & • & $\cdots$ & $\because$ & 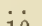 & $\cdots$ & $\cdots$ & $\cdots$ & 1 & $\ddot{i s}$ \\
\hline irshall & $\cdots$ & $\cdots$ & $\cdots$ & $\cdots$ & $\cdots$ & $\cdots$ & i & $\cdots$ & 6 & $\cdots$ & S & 1 & 5 & 2 & 4 & 6 & 10 & 4 & $\cdots$ & $\ldots$ & 33 & 13 \\
\hline Mas & $\cdots$ & $\cdots$ & $\cdots$ & $\cdots$ & $\cdots$ & $\cdots$ & 2 & $\cdots$ & 1 & . & $\cdots$ & $\cdots$ & 2 & 3 & . & . & . & $\cdots$ & $\ldots$ & $\cdots$ & 5 & 3 \\
\hline Me & $\cdots$ & $\cdots$ & $\cdots$ & $\cdots$ & $\cdots$ & $\cdots$ & $\cdots$ & $\cdots$ & $\cdots$ & $\cdots$ & $\cdots$ & $\cdots$ & $\cdots$ & $\cdots$ & ; & $\cdots$ & $\because$ & $\cdots$ & $\cdots$ & $\cdots$ & 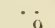 & $24^{*}$ \\
\hline leral & $\cdots$ & $\cdots$ & $\cdots$ & $\cdots$ & $\cdots$ & $\cdots$ & $\cdots$ & $\cdots$ & $\cdots$ & $\cdots$ & $\cdots$ & $\cdots$ & $\cdots$ & $\cdots$ & 4 & $\cdots$ & 5 & $\cdots$ & $\cdots$ & $\cdots$ & 9 & . \\
\hline Min & $\cdots$ & $\cdots$ & $\cdots$ & $\cdots$ & $\cdots$ & $\cdots$ & $\cdots$ & $\cdots$ & $\cdots$ & $\cdots$ & $\cdots$ & $\cdots$ & $\ddot{i}$ & $\cdots$ & 6 & $\cdots$ & $\cdots$ & $\cdots$ & $\cdots$ & $\cdots$ & 6 & $\cdots$ \\
\hline alia & $\cdots$ & $\cdots$ & $\cdots$ & $\cdots$ & $\cdots$ & $\cdots$ & $\because$ & $\cdots$ & $\ddot{\dot{S}}$ & $\cdots$ & $\because$ & $\cdots$ & 1 & $\cdots$ & is & $\cdots$ & 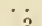 & $\cdots$ & $\ddot{i}$ & $\cdots$ & $\frac{1}{0}$ & $\cdots$ \\
\hline Mr & $\cdots$ & $\cdots$ & $\cdots$ & $\cdots$ & $\cdots$ & $\cdots$ & 4 & $\cdots$ & s & $\cdots$ & 3 & $\cdots$ & 30 & . & 19 & & 3 & $\cdots$ & 2 & $\cdots$ & 69 & $\cdots$ \\
\hline Nicholas & $\cdots$ & $\cdots$ & $\cdots$ & $\cdots$ & $\cdots$ & $\cdots$ & $\cdots$ & $\cdots$ & $\cdots$ & $\cdots$ & $\because$ & $\cdots$ & $\cdots$ & - & 5 & $\cdots$ & $\cdots$ & $\cdots$ & $\cdots$ & $\cdots$ & 5 & $\cdots$ \\
\hline Ohio & $\cdot$ & $\cdots$ & $\cdots$ & $\cdots$ & $\cdots$ & $\cdots$ & $\cdots$ & $\cdots$ & 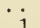 & $\cdots$ & 2 & $\cdots$ & $\dot{0}$ & $\cdots$ & $\dot{4} \dot{3}$ & $\cdots$ & $\ddot{2}=$ & $\cdots$ & $\because$ & $\cdots$ & $0^{2}$ & $\cdots$ \\
\hline hontas & 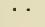 & $\cdots$ & $\ddot{i}$ & $\cdots$ & $\cdots$ & $\cdots$ & $\cdots$ & $\cdots$ & 1 & $\cdots$ & 5 & : & $6 !$ & $\because$ & 143 & $\cdots$ & 37 & $\cdots$ & 5 & $\cdots$ & 260 & ; \\
\hline Preston & $\cdots$ & $\cdots$ & 1 & $\cdots$ & $\cdots$ & $\cdots$ & $\cdots$ & $\cdots$ & 1 & . & . & 3 & 10 & 1 & $\cdots$ & $\cdots$ & 7 & $\cdots$ & . & $\cdots$ & 19 & 4 \\
\hline Raleigh & $\cdots$ & $\cdots$ & $\cdots$ & $\cdots$ & . & $\cdots$ & $\cdots$ & $\cdots$ & $\cdots$ & . & • & $\cdots$ & 1 & $\dot{7}$ & $\cdots$ & $\cdots$ & . & $\cdots$ & $\cdots$ & $\cdots$ & 1 & $\ddot{r}$ \\
\hline olph & $\cdots$ & · & $\cdots$ & $\cdots$ & $\cdots$ & $\cdots$ & $\ddot{3}$ & $\cdots$ & $\because$ & $\because$ & $\ddot{5}$ & $\ddot{2}$ & $\cdot$ & & $\cdots$ & $\cdots$ & $\cdots$ & $\because$ & $\cdots$ & $\cdots$ & $i$ & í \\
\hline itchie & · & $\cdots$ & $\cdots$ & $\cdots$ & $\cdots$ & $\cdots$ & 3 & $\cdots$ & 3 & : & 5 & 24 & 3 & 1. & is & $\cdots$ & . & 1 & $\cdots$ & $\cdots$ & 14 & 42 \\
\hline Ro: & $\cdot$ & $\cdots$ & $\cdots$ & $\cdots$ & $\cdots$ & $\cdots$ & $\cdots$ & $\cdots$ & $i$ & $\cdots$ & 5 & 14 & 10 & 18 & 10 & $\cdots$ & 2 & $\cdots$ & $\cdots$ & $\cdots$ & 27 & 32 \\
\hline ers & $\cdots$ & $\cdots$ & $\cdots$ & $\cdots$ & $\cdots$ & $\cdots$ & $\cdots$ & $\cdots$ & 14 & . & 12 & $\because$ & 22 & ; & 9 & $\cdots$ & 5 & $\cdots$ & $\cdots$ & $\cdots$ & 62 & $\because$ \\
\hline Taylor & . & $\cdots$ & $\cdots$ & $\cdots$ & $\dot{i}$ & $\cdots$ & $\cdots$ & $\cdots$ & $\cdots$ & . & 3 & 1 & 3 & 4 & $\cdots$ & $\cdots$ & ; & $\because$ & $\cdots$ & $\cdots$ & 6 & 5 \\
\hline Tyler & 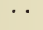 & - & $\cdots$ & $\cdots$ & 1 & $\cdots$ & $\cdots$ & . & $\cdots$ & ? & 1 & ii & $\cdots$ & 1 & 1 & & 2 & 1 & $\cdots$ & $\cdots$ & 5 & 2 \\
\hline Upshur & 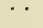 & $\cdots$ & $\cdots$ & $\cdots$ & $\cdots$ & $\cdots$ & . & $\cdots$ & $\because$ & 1 & $\cdots$ & 19 & $\cdots$ & S & 2 & 1 & . & $\cdots$ & $\cdots$ & $\cdots$ & 2 & 29 \\
\hline Wavi & 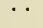 & $\cdots$ & $\cdots$ & $\cdots$ & $\cdots$ & $\cdots$ & $\cdots$ & $\cdots$ & 3 & 2 & $\cdots$ & . & $\because$ & & $\dot{5}$ & ; & $\cdots$ & $\cdots$ & $\cdots$ & $\cdots$ & 3 & 2 \\
\hline Webster & . & - & · & $\cdots$ & $\cdots$ & $\cdots$ & & • & 1 & - & $\because$ & $\because$ & & 13 & 5 & 1 & 10 & $i$ & $\cdots$ & $\cdots$ & ח & 14 \\
\hline Wetzel & ${ }^{\circ}$ & . & • & $\cdots$ & $\cdots$ & $\cdots$ & $\cdots$ & . & $\because$ & . & 3 & 1 & 6 & 10 & 4 & 1 & 10 & 4 & $\cdots$ & $\cdots$ & 23 & 16 \\
\hline Wirt & & $\cdots$ & - & $\cdots$ & $\cdots$ & $\cdots$ & $\cdots$ & $\cdots$ & 4 & . & 3 & ? & 1 & $\because$ & $\because$ & $\because$ & $\cdots$ & $\cdots$ & $\cdots$ & $\cdots$ & 8 & 0 \\
\hline Wood & . & $\because$ & $\cdots$ & $\cdots$ & $\cdots$ & $\cdots$ & $\cdots$ & $\cdots$ & 2 & . & 5 & 4 & 5 & 2 & 1 & 1 & $\cdots$ & $\cdots$ & $\cdots$ & $\cdots$ & 13 & 7 \\
\hline
\end{tabular}

Total

$\begin{array}{lllllllllllllll}1 & 2 & 1 & \ldots & 2 & \ldots & 13 & \ldots\end{array}$

T\& $25 \quad 14$

† None shipped during March and April, 1929. *Not distributed by months. 'Single deck. 2Double deck.

In some sections of the state each independent dealer had taken a large area to himself and effectively kept other buyers from making purchases in his territory. This was accomplished through agreements between dealers to keep ont of each other's territory. The agreements were enforced by means of retaliatory purchases at high prices if a buyer overstepped his territory. The livestock of the section was further controlled through the systems of contracting and of making loans on livestock which have been explained above.

Since records are not available, it is impossible to prove the truth or falsity of the accusations which were made against the dealers. Some farmers, however, were sufficiently dissatisfied with 
the prevailing marketing conditions to join in the formation of cooperative associations.

During the period 1920-25 the Farm Bureau, not only in West Virginia but in many other states as well, was actively engaged in promoting commodity marketing organizations. This was a period of rapid growth of cooperative marketing. Furthermore, the Agricultural Extension Division was just beginning to expand its livestock program during 1922 and 1923. Since 1919 cooperative livestock shipping had experienced a rapid growth in the neighboring state of Ohio. In 1920 the farmers in that state had formed a new type of livestock marketing organization-the "County Unit Plan." Dissatisfied with the old system of marketing and spurred on by the rapid development of the cooperative movement in other states, and particularly that in Ohio, some West Virginia farmers were eager to organize, and cooperative shipping associations were formed rapidly over the state.

\section{VOLUME OF BUSINESS}

The growth in the number of shipping associations in West Virginia would be more favorable to the record of its cooperative movement were it not for the high mortality rate which has been experienced. Only 13 of the 21 associations which had been organized functioned in 1929. During 1930 there was a net gain of one over 1929, since three old associations were revived, but two which had shipped in 1929 were inactive in 1930.

A better picture of the changing fortunes of the cooperative associations may be formed from the data in Table 5, which shows the number of animals, by kinds, marketed by each association, each year from 1924 to 1930, and from data in Table 6, which shows the annual summaries for all associations.

The data presented in Tables 5 and 6 indicate that the associations have not been able to maintain a consistent growth in volume of business, some of them never having reached again the volume which they had during their first two years of operation. The total volume for all associations in the state decreased each year from 1925 to 1930 .

Most of the associations increased their volume of business for two or three years, then took a decided slump, from which only a few have recovered in recent years. Others had a decreasing volume of business after the first year and finally ceased to function. This, however, is the course of development one might expect them to take, since dealer margins were probably decreased; some members of the cooperatives were paid more by the dealers than their livestock was worth, in an effort to kill off the association; disappointment with results, dissatisfaction with the management, and internal strife all worked to decrease the patronage after the first great effort at organization.

Changes in the total number of livestock in the state have un- 
doubtedly had some effect on the vo!ume of business, but this has not been nearly so important as the activity of the manager in listing livestock for shipment and the competition offered by independent dealers. Perhaps the biggest single problem of the cooperative shipping associations in the state has been to obtain capable and interested management.

TABLE 5-Number of animals by bind and by years, martieted by cooperative livestock stripping associations

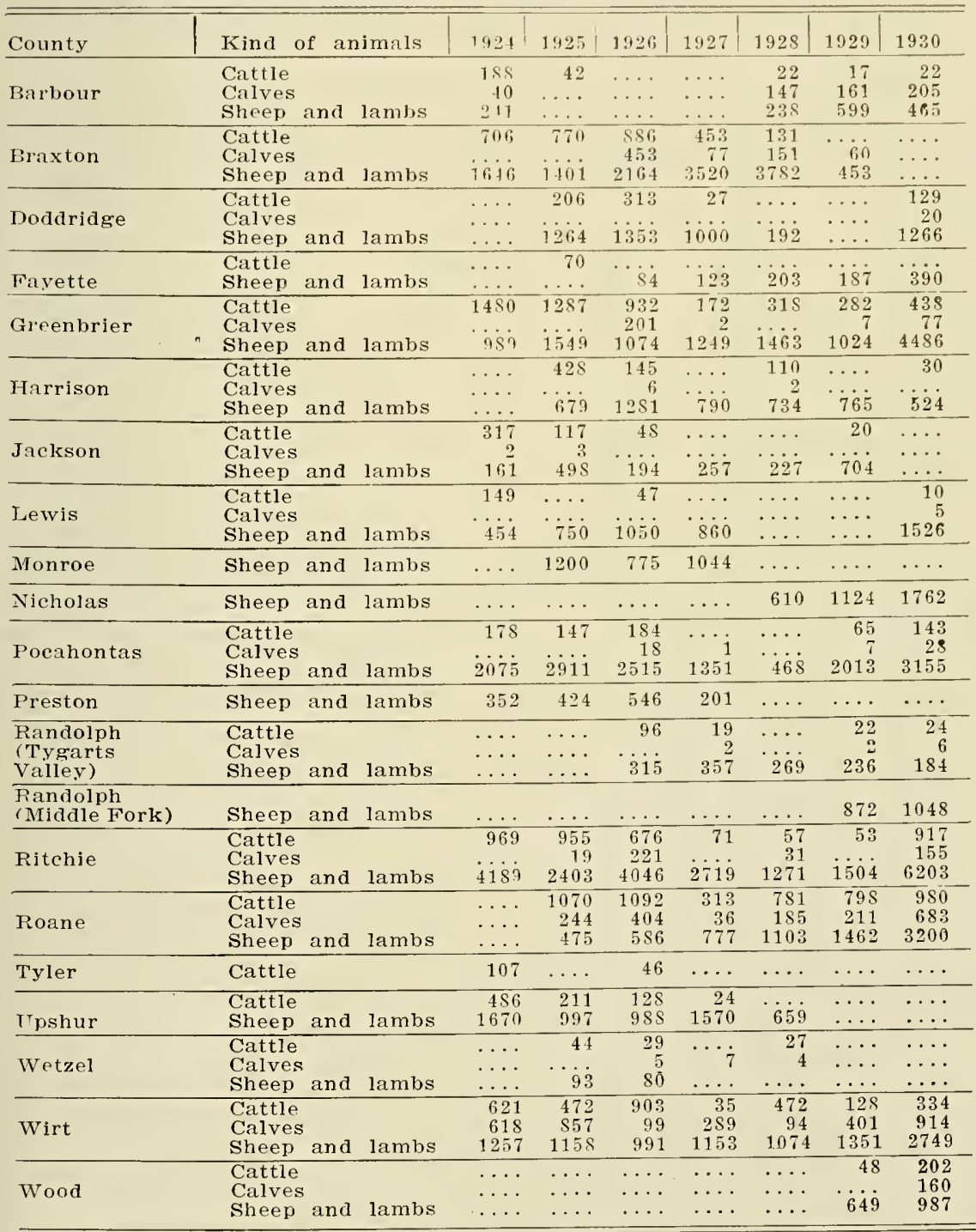


The present inactivity of many of the associations which have been formed has been due to the lack of a capable man who was willing to manage the association. Most of the experienced and capable men who might have been available for managers were engaged in trading and trafficking in livestock on their own account and have shown little interest in giving up this business to assume the managership of a cooperative shipping association. The most successful associations in the state are those which have obtained the services of experienced independent dealers who, for the most part, have given up trading on their own account.

TABLE 6-Summary of the business of all cooperative livestock shipping associations in West Virginia by years, 1924 to 1930, inclusive

\begin{tabular}{lccccr}
\hline Year & $\begin{array}{c}\text { Number of } \\
\text { cattle }\end{array}$ & $\begin{array}{c}\text { Number of } \\
\text { calves }\end{array}$ & $\begin{array}{c}\text { Number of } \\
\text { sheep and lambs }\end{array}$ & $\begin{array}{c}\text { Gross sales } \\
\text { value }\end{array}$ & $\begin{array}{c}\text { Net value to } \\
\text { producers }\end{array}$ \\
\hline 1924 & 5201 & 660 & 13,034 & $\$ 464,971.98$ & $\$ 420,501.23$ \\
1925 & 5819 & 1123 & 15,602 & $501,587.96$ & $460,427.03$ \\
1926 & 558 & 1407 & 18,042 & $501,501.12$ & $461,262.08$ \\
1927 & 1114 & 414 & 16,971 & $270,456.05$ & $251,955.24$ \\
1928 & 1918 & 614 & 12,293 & $288,794.79$ & $268,070.00$ \\
1929 & 1433 & 894 & 12,943 & $244,227.38$ & $224,535.01$ \\
1930 & 3229 & 2253 & 27,945 & $336,608.85$ & $294,157.78$ \\
\hline
\end{tabular}

The volume of business of the associations has been affected by changes in the degree of competition which was offered by independent dealers as a result of changes in livestock prices. During periods of rising prices for livestock, there has been more active competition on the part of independent dealers and, therefore, fewer animals have been shipped through the cooperative associations. The increase in the price level for livestock has accounted in some measure for the decreased volume of business of many associations. This increase at least is a factor which must be considered when studying the changes in volume. During periods of falling prices for livestock, especially in the second year of falling prices, the independent dealers have offered less active competition. It appears to be a characteristic of them that during such periods they do as little contracting as possible and that price offers for future delivery may be well below the current prices. Some of them cease activity entirely. More farmers, therefore, give their business to the shipping associations for that year. In 1930, West Viroinia was in its second year of falling livestock prices and this was largely responsible for the revival of the two old associations and the increased volume of business of almost all associations for that year.

The $\$ 501.000$ worth of livestock marketed bv cooperative shipping associations in West Virginia in 1925, the year of largest volume, is exceedinglv small when compared with the $\$ 41.199 .000$ worth of livestock marketed bv cooperatives in Missouri in 1925 (8):* with the $\$ 11,000,000$ business of cooneratives in Wisconsin in 1916 ( 5 ) and the $\$ 25,000,000$ business in $1923(6)$; with the $\$ 69,000,000$ busi-

\footnotetext{
*Reference is made by number (italic) to Bibliography, page 91 .
} 
ness of Minnesota cooperatives in 1919 (2); with the 560 carloads of the Arkansas associations in 1920 (7); or with the 67,523 single decks of livestock marketed by Iowa cooperative shipping associations in 1925 (1).

When volume of business is measured in terms of gross value of livestock marketed, the average per association in West Virginia was $\$ 31,348$ in 1925 , the year of largest volume, and $\$ 16,282$ in 1929 , the year of smallest volume. The range was from the $\$ 172$ business of the Wetzel county association in 1927 to the $\$ 154,794$ business of the Greenbrier county association in 1924. The Roane county association is the only one to show a consistent growth since its organization, the volume of business being greater each year than in any preceding year, with the exception of 1927, when there was a large decrease in volume.

Cooperative associations marketed approximately five percent of the sheep and lambs and thrce percent of the cattle and calves sent from West Virginia to out-of-state markets in 1929. The estimate is made from data contained in Tables 3 and 4 and from Table 5. In order to arrive at an estimate of the number of animals marketed from the state, it was considered that a single deck contained 140, and a double deck 260 lambs; that 25 cattle or 90 calves equalled an average carload. To the number of animals thus obtained by converting the data on car'oads to number of animals was added 15 percent, the estimated error due to incomplete records. The number of animals marketed from the state, estimated as indicated above, divided into the number of animals actually marketed by cooperative associations, gave the percentages referred to above.

The percentage of livestock produced in each county which was marketed by the cooperative associations is more significant than the percentage marketed cooperatively for the state as a whole, but the estimate is less reliable. By using the method explained above, the percentage of the total marketings from the county handled by each association in 1929 was estimated and is shown in Table 7.

After checking with several other estimates the percentages shown in Table 7 appear to be sufficiently accurate, with the exception of those for Fayette and Nicholas counties, to indicate the strength of the cooperative association in each county and the room for its expansion.

With the exception of the Wirt and Roane county associations, the cooperatives marketed a very small percentage of the livestock from counties in which they were operating. There are sufficient numbers of livestock in the counties to permit considerable expansion, if some of the obstacles indicated earlier can be overcome. It is thought by some people, however, that a larger volume of business would not contribute to the efficiency of the associations, and that those outside of the association profit as much and in the same manner as those patronizing the association. If both of these circumstances be true, then there is little use in putting forth the effort required for expansion. An attempt to answer these questions 
is made later when an analysis of costs and prices is presented.

Not only is the volume of business of the cooperative shipping associations in West Virginia small, but the percentage of total marketings from the state also is small in comparison with cooperatives in Iowa, which shipped 24 percent of the livestock marketed in the state in 1924 (1); with Minnesota cooperatives, which are estimated to have marketed 67 percent of all livestock shipped from points where associations were active in 1919 (2); with Wisconsin associations, which shipped approximately 50 percent of all carloads of livestock marketed from the state in 1923 (6); or with the Missouri cooperative associations, which marketed approximately 20 percent of the state's total in 1925 (8).

TABLE 7-Percentage of tolal out-of-state marketings of livestock handled by cooperative livestock shipping associations, by counties, 1929

\begin{tabular}{|c|c|c|}
\hline County & $\begin{array}{l}\text { Percentage of } \\
\text { cattle and calves }\end{array}$ & $\begin{array}{l}\text { Percentage of } \\
\text { sheep and lambs }\end{array}$ \\
\hline Barbour & 3 & $20^{1}$ \\
\hline Braxton $\ldots \ldots \ldots \ldots \ldots$ & 1 & 3 \\
\hline Fayette $\quad \ldots \ldots \ldots \ldots \ldots \ldots$ & . & $100^{2}$ \\
\hline Greenbrier $\ldots \ldots \ldots \ldots \ldots$ & 6 & 5 \\
\hline Harrison $\ldots \ldots \ldots \ldots \ldots \ldots$ & & $\mathbf{5}$ \\
\hline Jackson $\ldots \ldots \ldots \ldots \ldots \ldots \ldots \ldots$ & 0.6 & 10 \\
\hline Nicholas $\ldots \ldots \ldots \ldots \ldots \ldots$ & & $160^{3}$ \\
\hline Pocahontas $\ldots \ldots \ldots \ldots \ldots$ & 3 & 5 \\
\hline Randolph $\ldots \ldots \ldots \ldots \ldots \ldots$ & $\ldots$ & $\ldots$ \\
\hline Ritchie $\ldots \ldots \ldots \ldots \ldots \ldots$ & 3 & 11 \\
\hline Roane $\ldots \ldots \ldots \ldots \ldots \ldots \ldots$ & 27 & 12 \\
\hline Wirt $\ldots \ldots \ldots \ldots \ldots$ & 30 & $54^{5}$ \\
\hline Wood $\ldots \ldots \ldots \ldots \ldots \ldots \ldots$ & 4 & 18 \\
\hline
\end{tabular}

1 Barbour county trucked lambs to market; these were added to the railroad shipments to obtain total marketed from points within the county.

2 and ${ }^{3}$ Most of the livestock from Fayette and Nicholas counties was loaded at stations located in neighboring counties; therefore estimates on this basis are of questionable value.

${ }^{4}$ Complete records of railroad shipments not obtained for Randolph county.

5 Practically all of the lambs marketed by the cooperative association in Wirt county were shipped with calves and there was no indication of the number of cars which were classified in freight records as cattle and which as lambs.

\section{The Plan of Organization}

\section{THE COUNTY UNIT PLAN}

Cooperative livestock shipping associations in West Virginia are organized according to the "County Unit Plan," a plan modelled after the County Unit plan developed and adopted by Ohio livestock shippers after an intensive study of cooperative livestock shipping organizations in Illinois, Kansas, Nebraska, Minnesota, Iowa, and Canada. It was thought that this type of organization would be better adapted to Ohio conditions than would be the local unit as found in most states where cooperative shipping was being carried on. The significant feature of the County Unit plan is that it includes a larger territory in its operations than the local shipping association. In some respects conditions of livestock production in West Virginia are similar to those in Ohio; consequently it was thought by those sponsoring the movement that the County Unit plan also was better adapted than the local unit plan to West Virginia conditions. The 
shipping associations in West Virginia are non-stock bodies incorporated under the State Cooperative Marketing Act.

\section{CONSTITUTION AND BY-LAWS}

The constitution and by-laws are uniform for all associations in the state. They provide that the management of the county association shall be vested in a board of directors of five members. The president and vice-president are sclected from the membership of the board of directors, but the secretary-treasurer may be selected from the membership at large. The membership of the county association may include any reputable person, residing in the county in which the association is organized or in an adjoining county, who is a paid-up member of his county Farm Bureau.

If a non-member of the county Farm Bureau wishes to make use of the shipping association, he may do so by paying the same rates of commissions as the Farm Bureau members pay, but he is not entitled to any patronage dividends, which may be made only to Farm Bureau members. At present this is a weak point in the organization, for the Farm Burean in the state has lost heavily in membership, and in only a few cases have patronage dividends been paid. There is, therefore, little incentive for a farmer to join the Farm Bureau in order to become a member of the shipping association. In most counties little attention is given to membership in the associations, shipping being done for members and non-members on the same basis.

The Wirt county association was the only exception to the general policy of permitting non-members to ship without extra charge. This association charged 10 cents per hundrediveight above the regular commission charges for marketing the livestock of non-Farm Bureau members, and also did not permit their participation in patronage dividends.

The "constitution" further provides that the liability of a member of the shipping association shall not exceed the amount of his annual Farm Bureau dues.

The following duties of the officers of the board of directors are set forth in the by-laws:

"1. To manage the affairs of the association, including the hiring or discharging of the county manager, and fixing his compensation.

"2. To meet once each month during the shipping season and in special meetings upon call of the president.

"3. To require bond of every person handling or having in custody money or anything of value on account of the association. Failure to require bond renders the directors personally liable to the association for any loss resulting from such neglect.

"4. To secure the services of a competent auditor for auditing and submitting a report to the board of directors of the records of the county manager and of the treasurer.

“5. To take membership in the West Virginia Cooperative Livestock Shipping Association, Inc., and to nominate a member from their own board to be seated on the board of directors of the state association." 
The members of the board of directors are elected for three years, but no more than two come up for election in any one year. No person is eligible to be elected or to serve as a director if he is interested in or participates in a business in competition with the business of the county association.

The duties and powers of the county association manager as set forth in the by-laws are as follows:

"The duties of the county manager shall be actively to solicit business for the association; to be at the scales and yards on the day of shipment (unless he has secured a competent assistant) and receive all stock and weigh, properly mark, and load same on car; to have charge of and direct the sale of all shipments and receive all money therefor, and to pay same to the shippers, less the commission and other miscellaneous expenses connected with the shipment; to furnish a statement to each shipper showing the market weight, shrink, price received, and expenses; and to keep on file a complete record of each settlement on blank forms provided for such purpose.

"The county manager shall not buy livestock for himself or any other for shipment while he is in the employment of the association. The county manager shall keep the members of the association informed as to the market conditions and shall supply other information of value to them necessary to the successful operation of the association."

The duties and rights of members or consignees are as follows:

"Any person desiring to ship livestock through the association shall make such arrangements with his county manager, personally, by telegram or letter at least five days before he is ready to ship, giving the number and kind of livestock to be shipped, approximate weight, and date livestock will be delivered to the yards of the association for shipment. A member or consignee shall have the right to dispose of his livestock as he may wish, except that listed or promised for shipment through the association unless released by the county manager. In case any consignee is offered a price for his livestock which apparently is in excess of the net price that will be obtained by selling at the terminal market by the association, said consignee shall turn over the bid to the county manager, who shall handle it to the best interest of all concerned. In case a consignee orders space for shipment and fails to deliver his stock to the yards as per his agreements with the county manager, thereby causing loss to other shippers of the association, he shall be assessed the amount of the loss incurred. Failure to pay such loss shall bar the transgressor from further use of the association until such assessed loss has been paid.

"Any diseased animais and all stock which must be sold subject to inspection shall be received at the owner's risk and he shall receive such payment therefor as is received by the county manager, less all expenses figured prorata on the shipment. Any consignee whose stock is damaged after it is received by the county manager at the loading pens, or while in transit, shall receive the full value as though the stock had not been injured, but shall be subject to the same ratio of expense on the shipment. Any animal which is in a crippled or sick condition when delivered to the yards, shall be "eceived at the owners' risk."

The "manager's commission" and "insurance fund", as provided in the by-laws, is fixed as follows:

"There shall be deducted on every hundred pounds of live weight of cattle, sheep. and hogs shipped an amount to be determined by the board of directors, which amount shall be used for the necessary expenses of the association, such as insurance for paying losses that may occur to stock from 
the time it is received at the pens until final disposition is made of same; to pay the county manager for his selvices renrleled to the association, and to pay the cost of the board of directors' meetings and other miscellaneous expenses."

"The county manager shall be paid for his services a certain sum per hundred pounds of live weight, taken at the terminal market, on cattle, sheep, and hogs, and the board of directors shall fix the amount.

"It shall be the policy of the board of directors to establish a reserve from the savings of the insurance fund and, if there is a surplus after establishing a reasonable reserve fund, to declare a patronage dividend at the close of each shipping season to the Farm Bureau members on the basis of per hundred pounds of livestock consigned to the association. The members of the board of directors and the county manager shall receive a compensation of three dollars per day for each regular or special meeting of the board of directors attended and in addition five cents per mile for each mile travelled to and from each regular or special meeting provided the board of directors actually transacts business for the association."

\section{SOME PROVISIONS OF CONSTITUTION AND BY-LAWS NOT OBSERVED}

The provisions in the constitution and by-laws have not been carried out fully at all times and in all counties. The provision for membership has been disregarded to a large extent. In some of the counties any one who consigns livestock to the association has come to be considered a member. The patronage dividend has been paid in only a few cases and there remains, therefore, little financial inducement for a patron to become a member of the association since the Farm Bureau has not always been active in each county. This leaves a large number of the patrons as non-members, and these feel no particular obligations to the shipping association.

The provision of the by-laws that no person shall be eligible for membership on the board of directors who is interested in any business competing with the association has not been observed in all cases. There have been some instances in the state where members of the board of directors were buying and shipping livestock on their own account in competition with the association. In most cases this has worked to the detriment of the association.

Not all of the county managers have kept as accurate records of the transactions of the associations as are provided in the by- ${ }^{1}$ aws. A large number have failed to weigh all livestock before shipment. Some have not preserved their records in such condition that they could be audited as specified in the by-laws. Nor have all county managers refrained from buying and selling livestock on their own account. This circumstance has limited the success of the association in some counties.

The provisions of the by-laws most frequently violated are those which specify that a member shall notify the manager as to the number, kind, approximate weight of livestock, and the time he wants to ship, and shall turn over outside bids to the manager. The failure of members to list their livestock with the manager has resulted in a heavy freight charge to other members because of light shipments. There is no case on record of members being forced to pay the extra 
cost because of their failure to deliver livestock for shipment. Occasionally a member of the association has turned over a bid to the manager for livestock which he has agreed to ship. Often, however, the member uses the association as an alternative opportunity to make the independent dealer bid higher on his livestock.

\section{RELATION OF COUNTY ASSOCIATION TO STATE ASSOCIATION}

The county associations are federated into the West Virginia Cooperative Livestock Shippers' Association, Inc., with each county association having one representative on the board of directors. The functions of the state association are to promote cooperative shipping of livestock in the state; to assist the county associations in problems of production and marketing; and to advise with them concerning methods and costs of marketing so as to bring about uniformity of practices within the state. The state association is a member of the Producers' Co-operative Commission Association, of Pittsburgh, Pa. Through the state association the county associations also have membership in this commission firm, but the county associations are not required to market their livestock through it.

Each county association is supposed to send a monthly report of its business to the secretary of the state association and to pay membership dues of one cent per hundredweight, market weight, on all livestock marketed. The secretary of the state association is at present also the animal husbandman of the State Agricultural Extension Division, whose program dovetails so closely with the work of the state shipping association that it is impossible to separate some phases of the work of one organization from those of the other. In all of the undertakings of the shipping associations they are assisted by the county agricultural agents and members of the Agricultural Extension Division staff. Such assistance is given without cost to the cooperative association.

\section{The Aims of the Cooperative Livestock Shipping Associations in West Virginia}

It is too much to say that even a majority of their patrons thoroughly understand the aims of the cooperative livestock shipping associations in West Virginia. Many of them look on such organizations as just another marketing agency to be used only when there appears to be some immediate advantage from patronizing them. Among the leaders, however, there is a well-defined purpose toward the accomplishment of which they are definitely working.

The central aim held by the leaders for these organizations is to procure for the producers the highest net return on their livestock enterprises that is consistent with the general conditions of the industry. To accomplish this purpose it is necessary to carry on two lines of endeavor: first, to return to the producer as large a proportion of the "terminal market dollar" as possible; and second, to improve the quality of the livestock of the state. 
In order that the producer receive a larger share of the "terminal market dollar" than he would without the cooperative in the marketing field, the associations proceed along several lines of action. The first of these is found in the attempt to eliminate the profit of the independent dealers. The profit of the independent dealer is the difference between the terminal market selling price and the purchase price minus all expenses incident to his buying and selling. To eliminate this profit it is the purpose of the associations to market livestock at actual cost. This, however, may become a mere catch-phrase. Even though the association market the livestock at actual cost it does not necessarily follow that all or even a part of the profit which ordinarily goes to the independent dealer has been eliminated. If the profit is to be eliminated it is necessary that the actual marketing costs of the association be no larger than the costs of the competing independent dealer. If they are larger then only a part of the profit may be eliminated.

In attempting to eliminate the profit of the independent dealer it is necessary for the association not only to keep its money costs at least down to those of the competing dealer, but also to keep the shrinkage and loss from death and cripples at least down to the standard maintained by its competitors. This means the introduction of methods looking toward the proper handling of the animals while in transit to prevent injury, to procure a minimum of shrink, and to dispose of injured and dead anima's to the maximum advantage.

But a larger proportion of a small "terminal market dollar" may be less than a smaller proportion of a larger terminal market dollar. The purchase price and the marketing costs are only two factors involved in determining the dealer's profit. The third factor is the selling price.

If the total marketing costs, inc'uding losses of the cooperative associations, are equal to those of competing dealers, their profit has not been eliminated unless the cooperative receive also as high a terminal market price. To obtain an equally high terminal market price, the cooperative must obtain equally good selling service on the terminal market and must be as well prepared as the independent dealer to ship to the proper market at the time the animals are in the proper condition to realize such a price.

If the marketing costs, the terminal sales price, and the price paid to the producer are equal for the cooperative association and the independent dealer, then the profit of the latter has been eliminated. This, however, is not the full purpose of the cooperative, for the costs of the competing dealer mav be excessively high, or the sales prices may be excessively low. To realize their final goal the cooperatives must strive to lower marketing costs to the minimum in keeping with the service offered and to increase the sales price to the maximum in keeping with the quality of the animals sold.

The second line of endeavor to increase the net returns to the producer lies in bringing about an improvement in the quality of the livestock. This leads the cooperatives into what is essentially a 
production program. Endeavors to improve quality make little headway against methods of purchase used by independent dealers, who give quality little consideration in their price offers. If satisfactory results are to be obtained from efforts to improve quality of livestock, it is necessary that differences in quality be registered by differences in the price to the producers. Hence, if a cooperative is to return the highest possible net price to its patrons, it is necessary that its program for improvement in quality be accompanied by a method of payment such that the price, as it is affected by quality on the terminal market, be registered with the producer. This means that the livestock of each patron must be sold and paid for on a quality basis.

The aims of the cooperative associations are in keeping with sound principles in the economy of marketing livestock. The efficiency of West Virginia's cooperative shipping associations must be measured by the extent to which these aims have been realized. It is unfortunate that sufficient data are not available with which to measure accurately the extent of the accomplishments. It is possible to present some data for this purpose but it is necessary to resort to deductive reasoning to arrive at anything like a complete measure. An attempt to measure the accomplishments of the cooperative shipping associations in West Virginia is made in the following chapters.

\section{The Costs of Marketing Livestock Through Cooperative Shipping Associations in West Virginia}

Data on the cost of marketing livestock in years before the organization of cooperative shipping associations are not available. Neither has it been possible to obtain marketing cost data from independent dealers in the state, chiefly because none of them has kept an accurate record of his costs. It is therefore impossible to make a comparison of shipping association costs with the costs of marketing which prevailed before their organization, or with the marketing costs of their competitors, the independent dealers. It is possible, however, to show the amount of the various items entering into the total marketing cost of the shipping associations, and to form some judgment as to the reasonableness of these and the economy of the services which call for such expenditures. It is also possible to make a comparison of the net farm price received from each agency of marketing. If the cooperatives compete successfully with the independent dealers, it may be assumed that the latter will be forced to take a margin about equal to the total marketing cost of the associations, and to pay the farmer as much as the net price he would receive by marketing through the association.

In the following pages an analysis is made of the marketing costs of shipping associations, the services rendered, the economy of the services, and a comparison of prices received by producers from 
sales to the private dealer with those of sales through the cooperative associations.

The items of cost and the total cost of marketing sheep and lambs, cattle, and calves through the various cooperative shipping associations in the state are shown in Tables 8, 9, and 10, respectively. The costs were calculated from the records of the associations and were based on market weights of the animals sold. The costs on a few carloads which were marketed by the associations were not included because of inadequate records, and costs of two or three associations had to be omitted entirely. The rate of each item of

TABIE 8-Average costs per ewt. for marketing sheep and lambs through cooperative livestock shipping associations, by counties and items of cost, 1924 to 1929, inclusive

\begin{tabular}{|c|c|c|c|c|c|c|c|c|c|c|}
\hline County & 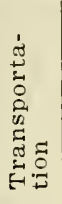 & 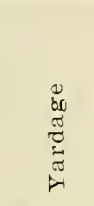 & 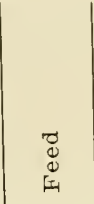 & 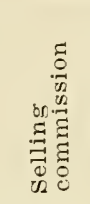 & 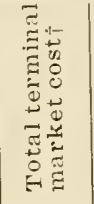 & 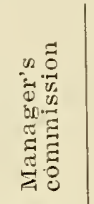 & 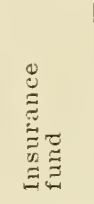 & 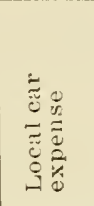 & 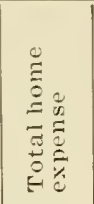 & 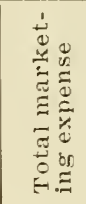 \\
\hline & $n t s)$ & (cents) & (cents) & (cents) & $(c c n t s)$ & (cents) & (cents) & (cents) & $(c(n t s)$ & (cents) \\
\hline Barbour & 102 & 10 & 004 & 30 & 142 & 09 & 12 & 01 & 22 & 164 \\
\hline Braxton & 56 & 12 & 03 & 27 & $9 \mathrm{~S}$ & 14 & 06 & 12 & 22 & 120 \\
\hline Greenbrier & 54 & 11 & 05 & 22 & 92 & 07 & 02 & & 09 & 101 \\
\hline Harrison & 49 & 11 & 05 & 23 & $\$ 8$ & 13 & 04 & 07 & 24 & 112 \\
\hline Jackson & 48 & 11 & 05 & 18 & 82 & 14 & 06 & 02 & 22 & 104 \\
\hline Nicholas & 69 & 13 & 06 & 25 & 113 & 12 & 05 & 11 & 28 & 141 \\
\hline Pocahontas & 65 & 10 & 04 & 19 & $9 \mathrm{~S}$ & 12 & 05 & 01 & 18 & 116 \\
\hline Roane* & 46 & 11 & 06 & 17 & 80 & 11 & 08 & 03 & 22 & 102 \\
\hline Wirt & 52 & 10 & 04 & 22 & 88 & 10 & $0 \mathrm{~s}$ & 05 & 23 & 111 \\
\hline
\end{tabular}

*Transportation costs, yardage, and selling commission were calculated on basis of animals going to market. Some animals were sold locally, or f. o. b., on which only home expenses were charged.

†Terminal market cost is the sum of transportation, yardage, feed, and selling commission costs.

expense as shown in the tables is an average of the cost per hundredweight on animals marketed by the associations from 1924 to 1929 inclusive. There has been little change in any of the fixed rates during this period. Of course, feed cost has varied somewhat but it is one of the small items of expense. The sum of these cost items represents the entire marketing cost to the producer with the following exceptions: (a) insurance on terminal market, which amounts to 15 cents per carload; (b) shrinkage; and (c) the expense of getting the animals to the shipping point, which is borne by the owner. The fee paid into the insurance fund covers insurance in transit. The producer also is reimbursed out of this fund for any loss due to death or injury of animals.

The average amount of each item of cost of marketing sheep and lambs for the various associations is shown in Table 8.

\section{THE COST OF MARKETING SHEEP AND LAMBS}

The total cost of marketing sheep and lambs as shown in Table 8 ranged from $\$ 1.01$ per cwt. for the Greenbrier county association to $\$ 1.64$ per cwt. for the Barbour county association. The total cost 
for each of the other associations was between these two extremes, but for the majority it was nearer the former figure. With these costs, the percentage of shrink, and the market quotations known, it is possible to calculate the approximate price which the producer should receive at the shipping point. Shrink, of course, is a variable factor, but calculations of the shrink on sheep and lambs marketed by the cooperatives show that it was on the average about 11 percent. (Table 28.) If, therefore, lambs of a certain quality were selling on the terminal market for $\$ 15$ per civt., the net price for such lambs received by a patron of the Greenbrier county association would have been, on an average, $\$ 2.66$ per cwt. below the terminal market price, but for a patron of the Barbour county association it would have been $\$ 3.29$ below the terminal market price. If, for the same service, independent dealers in these respective counties were taking on the average higher margins, then it was costing the producers more to market their livestock through them than it would if they patronized the shipping association. Since shrink is so important an item in determining the amount of the margin, that margin which is necessary to meet the marketing costs will vary with the terminal market price, being greater when the price is high than when it is low.

If during this period a dealer operated on the same margin, and rendered the same service as the cooperative association, he would have had, in Greenbrier county, only nine cents per cwt., but in Barbour county 22 cents out of which to pay his local expenses and to derive his profits. These amounts represent the sum of the cost items for manager's commission, insurance fund, and local car expense. Out of these sums would come all of the local expense incident to buying, shipping, and payment for losses, but not shrinkage. Good management might permit some reduction in transportation cost, yardage, and selling commission. If, therefore, it is found that a dealer is paying prices and rendering services equal to those of the cooperative associations, it may be assumed either that he has reduced his marketing costs by efficient management; that he has managed to sell on a higher market; or that his profit margin is reasonably small. If he is less efficient in all of these matters then he must be operating at a loss.

The total marketing cost on sheep and lambs of the Barbour county association was 62 percent higher than that of the Greenbrier association. Transportation cost was included in this total cost. A more accurate comparison of the operating efficiency may be had, however, if this item be eliminated. With the item of transportation cost eliminated, the Nicholas association becomes the highcost association with a remaining total cost of 72 cents per civt. as compared with 47 cents per cwt. for the Greenbrier unit. The sum of the remaining cost items for the former association was 53 percent higher than for the latter. Even with the cost of transportation eliminated, the difference in the amount of the remaining costs does not necessarily measure a difference in efficiency of the associa- 
tions. It becomes necessary to analyze the separate items of cost for each association; this is done further on.

\section{THE COST OF MARKETING CATTLE}

The total cost for marketing cattle through the cooperative associations is shown in Table 9. As in the case of sheep and lambs, the items of cost are averages for the cattle marketed by each association from 1924 to 1929 , inclusive. Calculations were made on the same basis as those indicated for sheep and lambs.

TABLE 9-Average cost per cwt. for marlieting cattle through cooperative livestocli shipping associations, by countics and items of cost, 1924 to 1929, inclusive

\begin{tabular}{|c|c|c|c|c|c|c|c|c|c|c|}
\hline County & 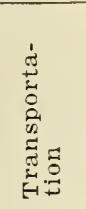 & 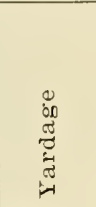 & $\begin{array}{l}\circlearrowright \\
0 \\
0 \\
\pm 1\end{array}$ & 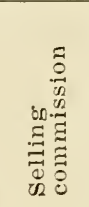 & 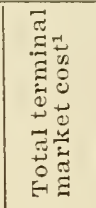 & 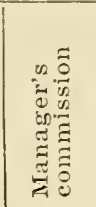 & 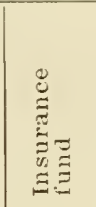 & 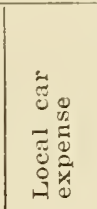 & 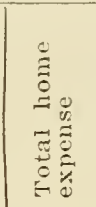 & 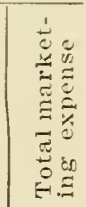 \\
\hline & $($ cents) & (cents) & (cents) & $($ cents $)$ & (cents) & (cents) & (cents) & (cents) & (cents) & (cents) \\
\hline Barbour & 52 & 05 & 05 & 17 & 79 & 09 & 09 & 03 & 21 & 100 \\
\hline Braxton & 41 & 05 & 05 & 16 & 67 & 07 & 06 & 03 & 16 & 83 \\
\hline Greenbrier & 46 & 03 & 06 & 11 & 66 & 06 & 01 & . & 07 & 73 \\
\hline Harrison & 27 & 04 & 06 & 11 & 48 & 09 & 05 & 04 & 18 & 66 \\
\hline Jackson & 37 & 03 & 07 & 13 & 60 & 05 & 06 & 01 & 12 & 72 \\
\hline Pocahontas & 50 & 04 & 05 & 15 & 74 & 08 & 06 & . & 14 & 88 \\
\hline Roane & 36 & 04 & 05 & 11 & 56 & 07 & 05 & $\dot{0} \dot{2}$ & 14 & 70 \\
\hline Wirt & 38 & 05 & 06 & 12 & 61 & 10 & 05 & 02 & 17 & 78 \\
\hline
\end{tabular}

1 Terminal market cost is the sum of transportation, yardage, feed, and selling commission costs.

The total marketing cost on cattle amounted to $\$ 1$ per cwt. for the Barbour county association, the high-cost unit, which was 51 percent more than the 66-cents cost of the Harrison county association, the low-cost cooperative. With transportation cost eliminated, the range of the sum of the remaining costs was from 27 cents per cwt. for the Greenbrier association, which becomes the low-cost association, to 48 cents per cwt. for the Barbour association, which remains the high-cost association, that of the latter being approximately 80 percent higher than that of the former.

As in the case of sheep and lambs, the total cost does not include the item of shrink. The average shrink on cattle marketed through the associations was approximately seven percent (Table 28). If cattle of a certain quality were selling on the terminal market for $\$ 10$ per cwt., a patron of the Barbour association would have received for such cattle, on the average, $\$ 1.70$ per cwt. less than the terminal market price, while a patron of the Harrison association would have received $\$ 1.36$ less. The home expenses of the Greenbrier organization, which was low in respect to these items, amounted to seven cents per cwt., but for the Barbour unit they amounted to 21 cents. This was the amount competing dealers would have had out of which to meet their local expenses if they were paying a price equal to the cooperative price. Table 9 shows that there was considerable variation between associations in the various items of cost for marketing cattle. 
The average amount of the different items of cost and the total cost of marketing calves through the various cooperative associations are shown in Table 10 . The same qualifications apply to these data as have been indicated for those pertaining to sheep and lambs and cattle.

The total marketing cost for calves, as shown in Table 10 , ranged from an average of 83 cents per cwt. for the Greenbrier association to $\$ 1.72$ per cwt. for the Barbour cooperative, the cost of the latter being 104 percent higher than that of the former. Shrink amounted, on the average, to about nine percent (Table 28).

If calves of a certain quality were sel'ing on the terminal market for $\$ 15$ per cwt., a patron of the Barbour association would have received for that quality of calves approximately $\$ 3$ per cwt. less than the terminal market price, while a patron of the Greenbrier association would have received on an average only $\$ 2.10$ per cwt. less.

TABLE 10-Average cost per cwt. for marketing calves through cooperative livestocti shipping associations, by counties and items of cost, 1924 to 1929, inclusive

\begin{tabular}{|c|c|c|c|c|c|c|c|c|c|c|}
\hline County & 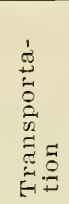 & 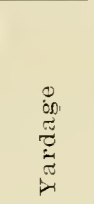 & 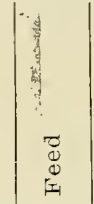 & 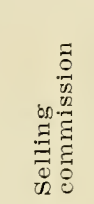 & 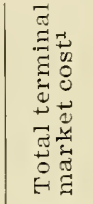 & 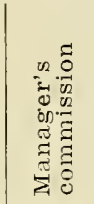 & 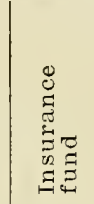 & 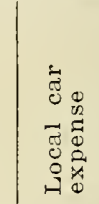 & 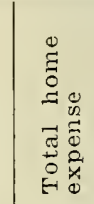 & 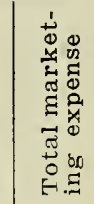 \\
\hline & (cent & (cents) & (cents) & (cents) & (cents) & (cents) & (cents) & (cents) & (cents) & $(c e n t s)$ \\
\hline Barbour & 112 & 11 & 01 & 27 & 151 & 11 & 09 & 01 & 21 & 172 \\
\hline Braxton & 73 & 12 & 03 & 22 & 110 & 0 & 0 & 03 & 16 & 126 \\
\hline Greenbri & 47 & 04 & 06 & 15 & 72 & 0 & 0 & & 1 & 83 \\
\hline Pocahontas & 51 & 03 & 04 & 15 & 73 & 1 & 0 & & 16 & 89 \\
\hline Roane & 52 & 07 & 04 & 16 & 79 & 10 & 0 & 0 & 21 & 100 \\
\hline Wirt & 51 & 12 & 02 & 16 & 81 & 10 & 05 & 04 & 19 & 100 \\
\hline
\end{tabular}

1 Terminal market cost is the sum of transportation, yardage, feed, and selling commission costs.

If the cost item for transportation be eliminated, the Barbour association remains the high-cost association, with a cost of 60 cents per cwt., and the Greenbrier association low, with a cost of 36 cents per cwt., the remaining cost of the former association being 66 percent higher than that of the latter. The home marketing expenses ranged from 11 cents per cwt. for the Greenbrier cooperative to 21 cents for the Roane and Barbour county associations.

\section{MARKETING COSTS IN WEST VIRGINIA COMPARED WITH THOSE IN OTHER STATES}

Reports of studies of cooperative shipping associations in other states show few cost data with which comparisons may be made. In Minnesota (2) the total marketing cost for 146 associations in 1917 was 29.1 cents per cwt., of which 19.6 cents was for freight and central market expenses and 9.5 cents for home expenses. Both the 
home and central market expenses were consirleralbly higher for the West Virginia than for the Minnesota associations.

The reports of some studies attempt to portray the efficiency of cooperative shipping associations by using as a measure the percentage of the gross sales value returned to the producer. This method is less accurate than one which shows the items of marketing cost in monetary terms. The total cost of marketing is composed, for the most part, of relatively fixed cost rates, which do not vary with the price of livestock. With cost rates fixed, the percentage of the gross sales value returned to the producer varies directly with the price of the livestock marketed. When livestock prices are high the producer will receive a larger percentage of the gross sales value than when prices are lower. By this method. therefore. the efficiency of one association cannot be compared adequately with that of another even within the same state. or within the same year. because there may be differences both in the grade of livestock marketed and in the charges on the varions terminal markets. All of these factors tend to lessen the significance of such a comparison.

TABLE 11-Percentage of gross sales returned to the producer by cooperative livestock shipping associations, by association and year, 1924-1929, inclusive*

\begin{tabular}{|c|c|c|c|c|c|c|}
\hline \multirow[t]{2}{*}{ Association } & 1924 & 1925 & 1926 & 1927 & 1928 & 1929 \\
\hline & (percent) & (percent) & (percent) & (percent) & (percent) & (percent) \\
\hline Barbour & $\$ 8.2$ & 89.1 & & & 86.9 & 72.5 \\
\hline Braxton & 92.9 & $\$ 9.6$ & 92.7 & $\dot{9} \dot{3} .5$ & 91.1 & 88.1 \\
\hline Doddridge & $\ldots$ & 90.6 & 93.6 & 91.5 & 88.6 & \\
\hline Fayette & & 85.0 & 86.9 & 90.9 & 90.3 & 91.1 \\
\hline Greenbrier & 90.0 & 91.2 & 91.8 & 93.0 & 94.6 & 94.1 \\
\hline Harrison & & 91.7 & 91.3 & 95.9 & 93.3 & 92.1 \\
\hline Jackson & 92.6 & 91.3 & 92.9 & 90.6 & 89.4 & $\$ 9.4$ \\
\hline Lewis & 88.1 & $99.2^{1}$ & $98.8^{1}$ & $98.4^{1}$ & . & $\cdots$ \\
\hline Monroe & . & $100.0^{1}$ & $97.9^{1}$ & 90.3 & & \\
\hline Nicholas & & & & & 88.4 & 88.8 \\
\hline Pocahontas & 91.4 & $\dot{9} \dot{5} .9$ & 89.4 & $\dot{90} .9$ & 90.9 & 89.4 \\
\hline & 96.6 & $99.5^{1}$ & 93.7 & $100.0^{1}$ & . & $\cdots$ \\
\hline \multicolumn{2}{|c|}{ Randolph (Tygarts } & & & & & \\
\hline \multirow{2}{*}{\multicolumn{2}{|c|}{$\begin{array}{l}\text { Valley) } \\
\text { Randolph (Middle }\end{array}$}} & . & 93.6 & 91.3 & $99.1^{1}$ & 90.5 \\
\hline & & & & & & $98.2^{1}$ \\
\hline Ritchie & 92.0 & 93.1 & 92.5 & 93.6 & $\ddot{9} \dot{4} .4$ & 92.0 \\
\hline Roane & & 90.2 & 91.0 & 95.3 & 94.6 & 94.1 \\
\hline Tyler & $\$ \dot{8} .4$ & & 93.6 & & & . \\
\hline Upshur & 88.9 & 91.2 & 90.6 & 90.6 & 91.2 & $\ldots$ \\
\hline Wetzel & 85.5 & 86.6 & 88.7 & $\$ 2.6$ & 63.2 & $\therefore$ \\
\hline Wirt & $\$ 7.4$ & 89.7 & 88.6 & 90.8 & $\$ 9.9$ & 91.1 \\
\hline Wood & $\ldots$ & $\ldots$ & $\ldots$ & . & $\cdots$ & 92.0 \\
\hline Average & 90.4 & 91.8 & 92.0 & 93.0 & 93.0 & 92.0 \\
\hline
\end{tabular}

*Calculated from records of Secretary, West Virginia Cooperative Livestock Shipping Association, Inc. Does not include patronage dividends. isold locally.

Since this method has been used in some studies of cooperative shipping associations and, in the absence of other data, is of some value for comparative purposes, the percentage of gross sales value returned to the producer by the various cooperative associations in West Virginia is shown in Table 11.

It may be observed from Table 11 that there was considerable variation in the percentage of gross sales value returned to the pro- 
ducer, both as between associations and years. Undoubtedly some of this variation was due to a difference in expenses. The average percentage of gross sales value returned to patrons of all cooperative shipping associations in the state ranged from 90.4 percent in 1924 to 93 percent in 1927 and 1928, but in 1928 the Wetzel county association returned only 63.2 percent. These percentages do not include patronage dividends which, if added. would increase the percentage slightly. This is about the same percentage as that reported for cooperative associations in Wisconsin when in 1923 they returned to the producer an average of 92 percent of the gross sales value $(6)$.

An analysis of the separate cost items for each association is presented in the following pages.

\section{AN ANALYSIS OF TRANSPORTATION COSTS BY ASSOCIATIONS}

Tables 14 to 22, inclusive,* show the transportation costs per cwt. for the various kinds of livestock marketed by cooperative shipping associations in West Virginia. The data for some associations were not available. The number of animals shown in the tables does not, in every instance, equal the number marketed by each association, as some animals were sold locally, some were sold f. o. b. shipping point, and of some the records were not accurate enough for use. The data, however, are for a very large percentage of all animals marketed by the associations. According to data in these tables, the percentage increase in actual transportation cost above minimum available cost was largest for sheep and calves, while cattle in most counties were transported at a cost near the minimun rate.

The increases in transportation costs were due primarily to three factors: small volume of business, inability to load up to the minimum weight set by the railroads, and poor management. Many of the associations attempt to market all livestock offered to them. They do this as a matter of supplying a service which enables the producers to send their livestock to market when it is ready to go. The small volume of business in conjunction with the attempt to give this service results in light loadings, mixed loads, and, in some

*Column 1 in Tables 14 to 22 shows the years for which data are presented; column 2, the number of animals on which transportation was paid; column 3. the market weight of the animals included in column 2; column 4, the actual sum paid for transportation on these animals to the various markets; column 5 , the average transportation cost per cwt.; column 6, the rate per cwt. at which the animals could have been shipped by railroad to the same markets to which they were shipped, provided (1) that the sheep were shipped in double-deck cars and loaded so as to reach minimum weight, (2) that calves were loaded up to minimum weight and shipped in double-decks or with loads of cattle which reached the minimum weight, and (3) that cattle were loaded so as to reach the minimum weight. Column 7 shows the total transportation cost if animals had been transported at minimum rate as given in column 6 . Column 8 shows the excess of the actual transportation cost above the minimum cost given in column 7. Column 9 shows the percentage the excess in transportation cost was of the minimum cost. Column 10 shows the increased cost per cwt. due to failure to transport at minimum rate. Data in columns 9 and 10 are the important ones in this series of tables. 
cases, shipments by truck. If each association could have harl a sufficient volume of business to ship a full carload of one kind of animal once or twice each weck during the marketing season, it could have given adequate service and at the same time could have transported the livestock at the minimum rate. The minimum weight for which freight rates are shown in Tables 14 to 22 is 18.000 pounds for a double-deck of sheep; 22,000 pounds for a double-dech of calves; and 22,000 pounds for a carload of cattle. Shippers assert that it was practically impossible to load enough lambs in a car to reach the minimum weight of either a single or double deck. In view of this, therefore, the lowest rate which the shippers could obtain was somewhat higher than the minimum shown in Tables 14 to 22 for sheep and lambs, even though there were a sufficient volume to permit full loadings.

TABLE 12-Average weight of carloads of livestoct shipped by cooperative associations, by kind of shipment

\begin{tabular}{|c|c|c|c|c|c|c|c|c|}
\hline $\begin{array}{c}\text { County } \\
\text { association }\end{array}$ & 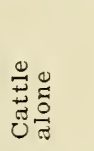 & 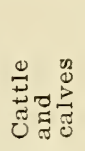 & 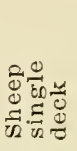 & 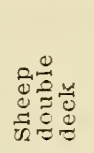 & 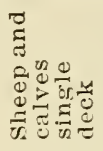 & 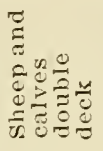 & 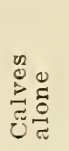 & 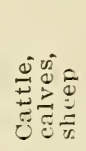 \\
\hline Braxton & 22,476 & 22,435 & 9835 & 16,000 & 11,160 & $\ldots \ldots$ & 8810 & $\ldots \ldots$ \\
\hline Greenbrier & 25,677 & 22,964 & 8470 & 17,123 & $\ldots \ldots$ & $\ldots \ldots$ & $\ldots$ & $\ldots$. \\
\hline Harrison & 24,764 & 24,190 & 8765 & 14,707 & $\ldots$ & $\ldots \ldots$ & $\ldots$ & $\ldots \ldots$ \\
\hline Jackson & 19,270 & $\ldots \ldots$ & 8377 & 13,262 & $\ldots \ldots$ & $\ldots \ldots$ & $\ldots$ & $\ldots \ldots$ \\
\hline Nicholas & & & 8940 & & $\ldots \ldots$ & $\ldots \ldots$ & $\ldots$ & $\ldots \ldots$ \\
\hline Pocahontas & 23,130 & 16,530 & 9493 & 15,430 & & & $\cdots$ & 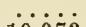 \\
\hline Roane & 24,578 & 23,750 & 9265 & 15,355 & 9,650 & 15,925 & 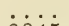 & 19,073 \\
\hline Wirt & 20,461 & 17,439 & 7946 & $\ldots \ldots$ & 11,071 & 16,800 & $\$ 845$ & 15,190 \\
\hline
\end{tabular}

The average weight of the carloads of livestock loaded by the various associations is shown in Table 12. The averages were calculated on the basis of all livestock shipped by each association since 1924. These averages are significant in an analysis of the transportation costs of the various associations, because they indicate either a lack of sufficient volume for the most economical transportation, or poor management, or both.

Table 13 shows the percentage of the animals transported in various kinds of shipments. It is evident from the data in the table that a large proportion of the animals were transported in mixed shipments, which played a part in increasing the transportation costs.

\section{The Braxton County Association}

The transportation costs on livestock marketed by the Braxton county association are shown in Table 14.

It cost the Braxton association an average of 9.8 cents per cwt., or 21.8 percent, more to transport its sheep and lambs to market than it would have cost to send them to the same markets if they had been transported at the minimum rate available. For a patron shipping 50 lambs of average weight this meant a loss of approximately $\$ 4$. An analysis of the records of the association shows that 
TABLE 13-Percentage of total number of animals shipped by cooperative associations tra? ported by designated hind of shipment, 1924 to 1929, inclusive

\begin{tabular}{|c|c|c|c|c|c|c|c|c|c|c|c|c|c|c|c|}
\hline Association & 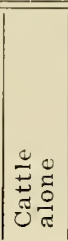 & 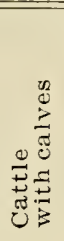 & 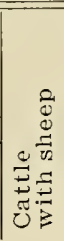 & 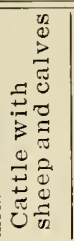 & 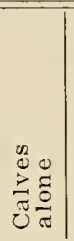 & 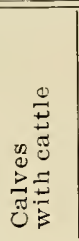 & 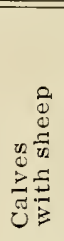 & 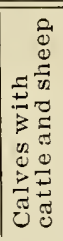 & 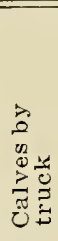 & 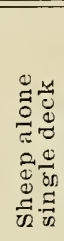 & 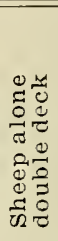 & 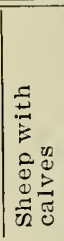 & 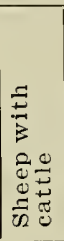 & 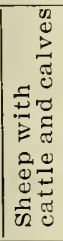 & $\underset{\Phi}{\Phi}$ \\
\hline n & 227 & & & 100.0 & 591 & $34 . S$ & & 5.5 & @0.9 & 9.8 & 38.4 & 15.4 & & 2.2 & 82 \\
\hline & & & & $\cdots$ & 39.1 & & 10.7 & : & $\cdots$ & 1 & & 3.7 & & $\because$ & \\
\hline & & 22.7 & $3 . \dot{8}$ & $\because$ & $\therefore$ & 100.0 & & $\cdot$ & 1.4 & & & $\ldots$ & 2.0 & .. & \\
\hline & 100.0 & & & 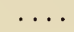 & & & . & & & & & .. & 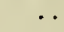 & .. & \\
\hline & & & . & $\cdots$ & & 100 & & & & & & . & & . & \\
\hline ta & & & $\ldots$ & & & & & 7. & & & & $\because$ & - & $\ddot{20}$ & \\
\hline Wirt & & $\begin{array}{l}7.0 \\
46.6\end{array}$ & $\because$ & 0.0 & 16.7 & 7.5 & 66.7 & 9.1 & .. & $21 . \bar{T}$ & 3.0 & 66.8 & $\therefore$ & 8.5 & \\
\hline
\end{tabular}

this increased cost was the result of shipments by single deck, 9.8 percent being shipped to market in this manner; and light loading and shipment of calves and lambs together, 1.6 percent being thus shipped. When lambs and calves are shipped together the load takes the sheep rate and the calf-minimum weight. It appears, however, to be difficult to load to the minimum weight in such a shipment. It is obvious from data presented in Table 12 that the average weight of the loads of lambs shipped by this association was much below the minimum fixed by the railroads in the case of

TABLE 14-Transportation costs on livestock marketed by the Braxton county association, by years, compared with costs if livestock had been transported at minimum freight rates by railroads

\begin{tabular}{|c|c|c|c|c|c|c|c|c|c|}
\hline Year & 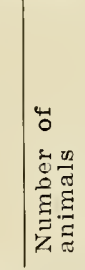 & 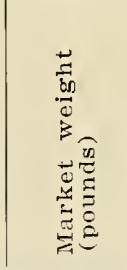 & 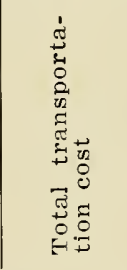 & 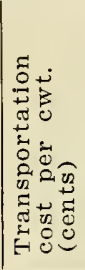 & 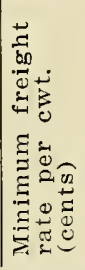 & 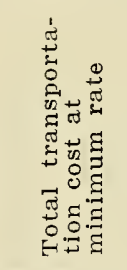 & 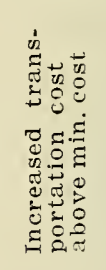 & 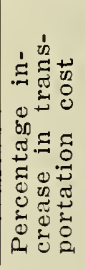 & 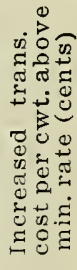 \\
\hline \multicolumn{10}{|c|}{ SHEEP AND LAMBS } \\
\hline $\begin{array}{l}1927 \\
1928 \\
1928\end{array}$ & $\begin{array}{r}3512 \\
3368 \\
453\end{array}$ & $\begin{array}{r}230,190 \\
210,210 \\
28,190\end{array}$ & $\begin{array}{r}\$ 1266.83 \\
1158.95 \\
176.31\end{array}$ & $\begin{array}{l}55.0 \\
55.1 \\
62.5\end{array}$ & $\begin{array}{l}45.0 \\
45.8 \\
46.3\end{array}$ & $\begin{array}{r}\$ 1046.53 \\
964.81 \\
130.78\end{array}$ & $\begin{array}{r}\$ 220.30 \\
194.14 \\
45.53\end{array}$ & $\begin{array}{l}21.0 \\
20.0 \\
34.8\end{array}$ & $\begin{array}{r}9.5 \\
9.3 \\
16.2\end{array}$ \\
\hline Total & 7333 & 468,590 & $\$ 2602.09$ & 55.5 & 45.7 & $\$ 2142.12$ & $\$ 459.97$ & 21.4 & 9.8 \\
\hline \multicolumn{10}{|c|}{ CALVES } \\
\hline $\begin{array}{l}1927 \\
1928 \\
1929 \\
\end{array}$ & $\begin{array}{r}75 \\
140 \\
52\end{array}$ & $\begin{array}{r}12,315 \\
21.180 \\
9,165\end{array}$ & $\begin{array}{r}\$ 103.29 \\
134.34 \\
75.15\end{array}$ & $\begin{array}{l}83.8 \\
63.4 \\
82.0\end{array}$ & $\begin{array}{l}43.9 \\
43.7 \\
44.0\end{array}$ & $\begin{array}{r}\$ 44.08 \\
92.64 \\
40.32\end{array}$ & $\begin{array}{r}\$ 49.21 \\
41.70 \\
34.83\end{array}$ & $\begin{array}{l}90.9 \\
45.0 \\
86.0\end{array}$ & $\begin{array}{l}39.9 \\
19.7 \\
38.0\end{array}$ \\
\hline Total & 267 & 42,660 & $\$ 312.78$ & 73.3 & 43.8 & $\$ 187.04$ & $\$ 125.74$ & 67.2 & 29.5 \\
\hline \multicolumn{10}{|c|}{ CATTLE* } \\
\hline $\begin{array}{l}1927 \\
1928 \\
\end{array}$ & $\begin{array}{l}190 \\
113 \\
\end{array}$ & $\begin{array}{l}195,505 \\
102,528\end{array}$ & $\begin{array}{r}\$ \pm 56.27 \\
429.56 \\
\end{array}$ & $\begin{array}{l}40.7 \\
41.8 \\
\end{array}$ & $\begin{array}{l}41.0 \\
41.2 \\
\end{array}$ & $\begin{array}{r}802.82 \\
423.02 \\
\end{array}$ & $\begin{array}{r}-6.55 \\
6.54 \\
\end{array}$ & $\ldots$ & $\begin{array}{r}-00.3 \\
00.6 \\
\end{array}$ \\
\hline Total & 203 & 298,033 & $\$ 1225.83$ & 41.1 & 41.1 & $\$ 1225.84$ & $\ldots \ldots$ & $\cdots$ & $\ldots$ \\
\hline
\end{tabular}

* No cattle marketed in 1929. 
single deck and double-deck, as well as in mixed shipments of calves and sheep. The average weight of the single decks was 9,835 pounds, of the double-decks 16,000 pounds, and of the mixed shipments of calves and sheep 11,160 pounds.

The transportation cost for calves was 29.5 cents per cwt., or 67.2 percent, more than the minimum rate available. Fifty-nine percent of the calves were shipped in straight shipments, 34.8 percent with cattle, and 5.9 percent with sheep. This increased cost was the result of light loading and mixed shipments, particularly of calves with lambs. The average weight, 8,810 pounds, of a few straight shipments of calves was far below the minimum for even a single deck. It is possible to ship calves with cattle without increasing the rate above the cattle rate, provided there is not a sufficient number of calves to prevent loading to the minimum cattle weight.

Cattle were transported on an average at a cost near the minimum rate. Only 22.7 percent were marketed in straight cattle shipments, while 77.2 percent were shipped with calves. The number of cattle marketed was not large, but it is easier to load them to the minimum weight. The manager of the association is also more likely to refuse to ship cattle if a full load is not available. Table 12 shows that the average weights of shipments of both cattle and mixed shipments of cattle and calves made by this association were a little more than the minimum requirements to procure the minimum rate.

\section{The Greenbrier County Association}

The transportation costs on livestock marketed by the Greenbrier association are shown in Table 15.

It cost the Greenbrier county association 7.4 cents per cwt., or 15.9 percent, more than the minimum rate to transport its lambs to market. This increased cost was also due to shipments by sing'e deck, 18.6 percent being thus transported; light loading; and mixed shipments of lambs and calves, 3.7 percent of which were thus transported. A larger percentage of the lambs were shipped in doubledecks by this association than by most of the others. It may be observed from Table 12 that the average weight of the single-deck loads, 8,470 pounds, was considerably below the minimum, but that the average weight of the double-deck loads, 17,123 pounds, was well up to the minimum.

The calves were shipped with cattle and loaded in such a way as to obtain the minimum catt'e rate. Likewise, shipments of cattle were transported at the minimum rate. The management of this association has been able to transport cattle and calves at the minimum rate available, but has failed to keep transportation costs to the minimum on sheep and lambs.

\section{The Harrison County Association}

The transportation costs on livestock marketed by the Harrison association are shown in Table 16. 
TABLE 15-Transportation costs on livestocti marketed by the Greenbrier county association, by years, compared with costs if livestock had been transported at minimum freight rates on railroads

\begin{tabular}{|c|c|c|c|c|c|c|c|c|c|}
\hline Year & 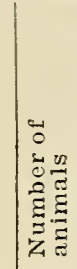 & 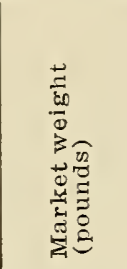 & 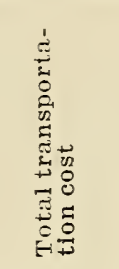 & 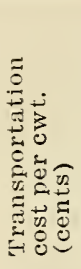 & 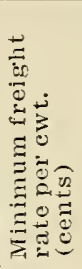 & 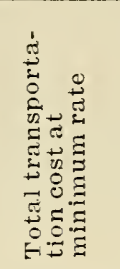 & 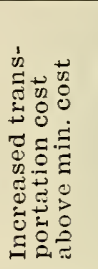 & 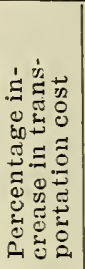 & 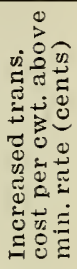 \\
\hline \multicolumn{10}{|c|}{ SHEEP AND LAMBS } \\
\hline$\overline{1923}$ & 1705 & 114,225 & $\$ 6 \$ 2.94$ & 59. & 47.5 & $\$ 542.56$ & $\$ 140.28$ & 25.8 & 12.3 \\
\hline 1924 & 988 & 69.585 & 419.42 & 60.3 & 47.5 & 330.53 & 88.89 & 26.8 & 12.8 \\
\hline 1925 & 1549 & 107,660 & & 56 & & & 96. & & 9.0 \\
\hline 1926 & 1074 & 0 & .76 & 53. & 47.5 & 347.27 & 40 . & 11.6 & 5. \\
\hline 1927 & 1249 & 280 & .38 & 50.6 & 47.5 & 419.33 & 27.05 & 6.4 & 3.1 \\
\hline & & & & $5 \overline{5}$ & & & 73.06 & 15.9 & 7.5 \\
\hline 1929 & 1025 & & 309.07 & 42.7 & 42.7 & 309.07 & $\ldots \ldots$ & $\ldots$ & ... \\
\hline Total & 9053 & 621,750 & $\$ 33 \$ 5.06$ & 54.4 & 47.0 & $\$ 2318.73$ & $\$ 466.33$ & 15.9 & 7.4 \\
\hline
\end{tabular}

CALVES

$\begin{array}{lllllllllll}\text { Total* } & 770 & 150,880 & \& 701.59 & 46.5 & 46.5 & \$ 701.59 & \ldots \ldots & \ldots & \ldots\end{array}$

CATTLE

\begin{tabular}{lllllllllll}
\hline Total* & 5505 & $6,236,261$ & $\$ 28,514.89$ & 45.7 & 45.7 & $\$ 28,514.89$ & $\ldots \ldots$ & $\ldots$ & $\ldots$
\end{tabular}

* Complete record by years not available.

The Harrison association paid an average of 12.5 cents per cwt., or 34.4 percent, more than the minimum rate to transport its sheep and lambs to market. This increased cost was due to light loadings and some shipments by single deck. By referring to Table 12 it may be seen that the average weight of both single and double decks of lambs shipped was considerably below the minimum neces-

TABLE 16-Transportation costs on livestock marketed by Harrison county association, by years, compared with costs if livestoch had been transported at minimum freight rates on railroads

\begin{tabular}{|c|c|c|c|c|c|c|c|c|c|}
\hline Year & 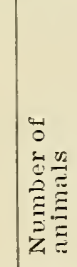 & 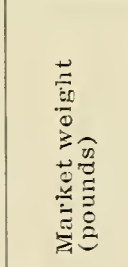 & 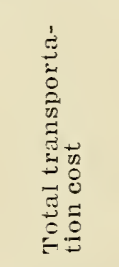 & 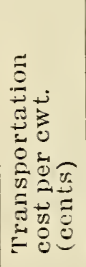 & 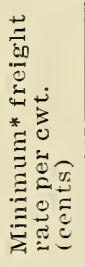 & 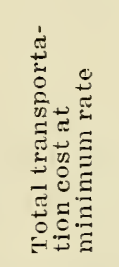 & 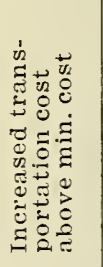 & 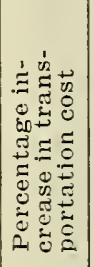 & 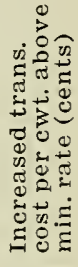 \\
\hline \multicolumn{10}{|c|}{ SHEEP AND LAMBS } \\
\hline $\begin{array}{l}1925 \\
1926 \\
1929\end{array}$ & $\begin{array}{l}375 \\
918 \\
765\end{array}$ & $\begin{array}{l}25,675 \\
62,902 \\
47,975\end{array}$ & $\begin{array}{r}\$ 138 . \$ 1 \\
302.49 \\
224.33\end{array}$ & $\begin{array}{l}54.1 \\
48.1 \\
46.8\end{array}$ & $\begin{array}{l}41.6 \\
36.3 \\
33.3\end{array}$ & $\begin{array}{r}\$ 106.90 \\
\mathbf{2 2 8 . 2 1} \\
159.80\end{array}$ & $\begin{array}{l}31.91 \\
74.28 \\
64.53 \\
\end{array}$ & $\begin{array}{l}29.8 \\
32.5 \\
40.4 \\
\end{array}$ & $\begin{array}{l}12.5 \\
11.8 \\
13.5 \\
\end{array}$ \\
\hline Total & 2088 & 136.552 & $\$ 665.63$ & 48.7 & 36.2 & $\$ 494.91$ & $\$ 170.72$ & 34.4 & 12.5 \\
\hline \multicolumn{10}{|c|}{ CATTLE } \\
\hline $\begin{array}{l}1925 \\
1926\end{array}$ & $\begin{array}{l}404 \\
162\end{array}$ & $\begin{array}{l}390,110 \\
171,150\end{array}$ & $\begin{array}{r}\$ 1045.85 \\
457.53\end{array}$ & $\begin{array}{l}26.8 \\
26.7\end{array}$ & $\begin{array}{l}26.7 \\
26.4\end{array}$ & $\begin{array}{r}\$ 1041.96 \\
453.49\end{array}$ & $\begin{array}{l}3.92 \\
4.04\end{array}$ & $\begin{array}{l}00.4 \\
00.9\end{array}$ & $\begin{array}{l}0.1 \\
0.3\end{array}$ \\
\hline Total & 566 & 561,260 & $\$ 1503.41$ & 26.1 & 26.6 & $\$ 1495.45$ & 7.96 & 00.4 & 0.1 \\
\hline
\end{tabular}

* Minimum rate is for double decks of sheep and calves. 
sary to obtain the minimum freight rate. The average weight of single decks shipped by this association was 8,765 pounds and of double decks 14,707 pounds. Cattle and calves were transported at the minimum rate available.

\section{The Jackson County Association}

The transportation costs on livestock marketed by the Jackson association are shown in Table 17.

Records were available for only one year's business of the Jackson association. During this year it cost the association 15.7 cents per cwt., or 48 percent, more to market its sheep and lambs than the minimum rate available, and 2 cents per cwt., or 5.7 percent, more to market its cattle. These increased costs, again, were the result of light loadings and shipments by single deck. The average weight of all shipments was considerably below the minimum weight for that kind of shipment. A patron shipping 50 lambs of average weight would have lost more than \$6 because of this increased transportation cost, while one shipping a thousand-pound steer would have lost 20 cents.

TABLE 17-Transportation costs on livestock marlieted by the Jaclson county association, by years, compared with costs if livestoch had been transported at minimum freight rates on railroads

\begin{tabular}{|c|c|c|c|c|c|c|c|c|c|}
\hline Year & 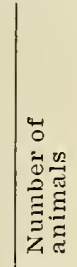 & 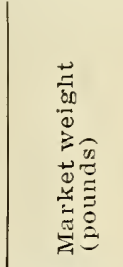 & 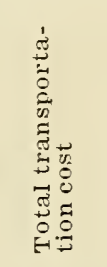 & 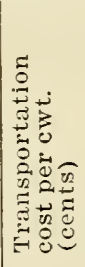 & 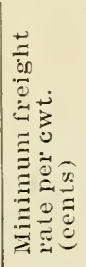 & 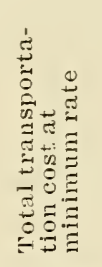 & 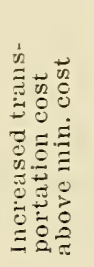 & 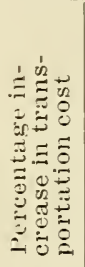 & 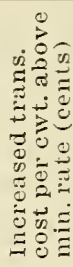 \\
\hline \multicolumn{10}{|c|}{ SHEEP AND IAAMBS } \\
\hline$\overline{1929}$ & 710 & 43,280 & $\$ 209.46$ & 48.3 & 32.6 & $\$ 141.45$ & $\$ 68.01$ & 48.0 & 15.7 \\
\hline \multicolumn{10}{|c|}{ CATTLE } \\
\hline$\overline{1929}$ & 20 & $\overline{19,270}$ & $\$ 71.30$ & 37.0 & 35.0 & $\$ 67.45$ & $\$ 3.85$ & 5.7 & 2.0 \\
\hline
\end{tabular}

\section{The Nicholas County Association}

Table 18 shows the transportation costs on livestock marketed by the Nicholas association.

The transportation cost on sheep and lambs marketed by the Nicholas association was 15.2 cents per cwt., or 28.3 percent, more than the minimum freight rate. An analysis of the records of this association shows that the increase was caused by light loading and shipments in single rather than double decks. All shipments were in single decks which averaged only 8,940 pounds, considerably below the minimum weight of 18,000 pounds necessary to obtain the minimum rate on double-decks, on which these ca!culations were based.

\section{The Pocahontas County Association}

In Table 19 the transportation costs on livestock marketed by the Pocahontas association are given. 
TABLE 18-Transportation costs on sheep and lambs marketed by the Nicholas county association, by years, compared with costs if livestock had been transported at minimum freight rates on railroads

\begin{tabular}{|c|c|c|c|c|c|c|c|c|c|}
\hline Year & 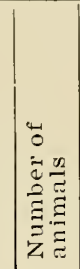 & 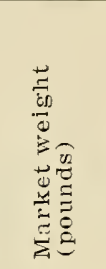 & 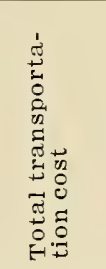 & 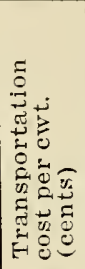 & 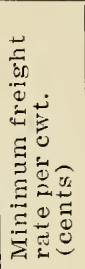 & 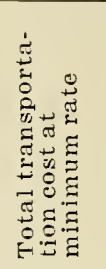 & 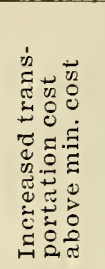 & 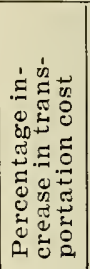 & 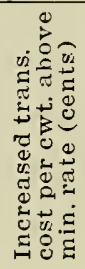 \\
\hline $\begin{array}{l}1928 \\
1929\end{array}$ & $\begin{array}{r}610 \\
1123\end{array}$ & $\begin{array}{l}37,755 \\
69.530\end{array}$ & $\begin{array}{r}\$ 260.90 \\
477.81\end{array}$ & $\begin{array}{l}69.0 \\
68.7\end{array}$ & $\begin{array}{l}53.0 \\
53.9\end{array}$ & $\begin{array}{r}\$ 200.52 \\
374.81\end{array}$ & $\begin{array}{r}\$ 60.38 \\
103.00\end{array}$ & $\begin{array}{l}30.0 \\
27.0\end{array}$ & $\begin{array}{l}16.0 \\
14.8\end{array}$ \\
\hline Total & 1733 & 107,285 & $\$ 738.71$ & 68.8 & 53.6 & $\$ 575.33$ & $\$ 163.38$ & 28.3 & 15.2 \\
\hline
\end{tabular}

For the Pocahontas cooperative the average transportation cost for sheep and lambs was 17.9 cents per cwt., or 37.7 percent, above the minimum rate; 7.8 cents, or 18.2 percent, above, for calves; and 7.1 cents, or 16.4 percent, above, for cattle. An analysis of the records of this association shows that the increase in transportation cost on sheep and lambs was due to light loading and shipment by single deck; on calves and cattle it was due to light loads of mixed shipments of cattle and calves. The average weights of various kinds of loads shipped by this association are given in Table 12.

TABLE 19-Transportation costs on livestock marketed by the Pocahontas county association, by years, compared with costs if livestock had been transported at minimum freight rates on railroads

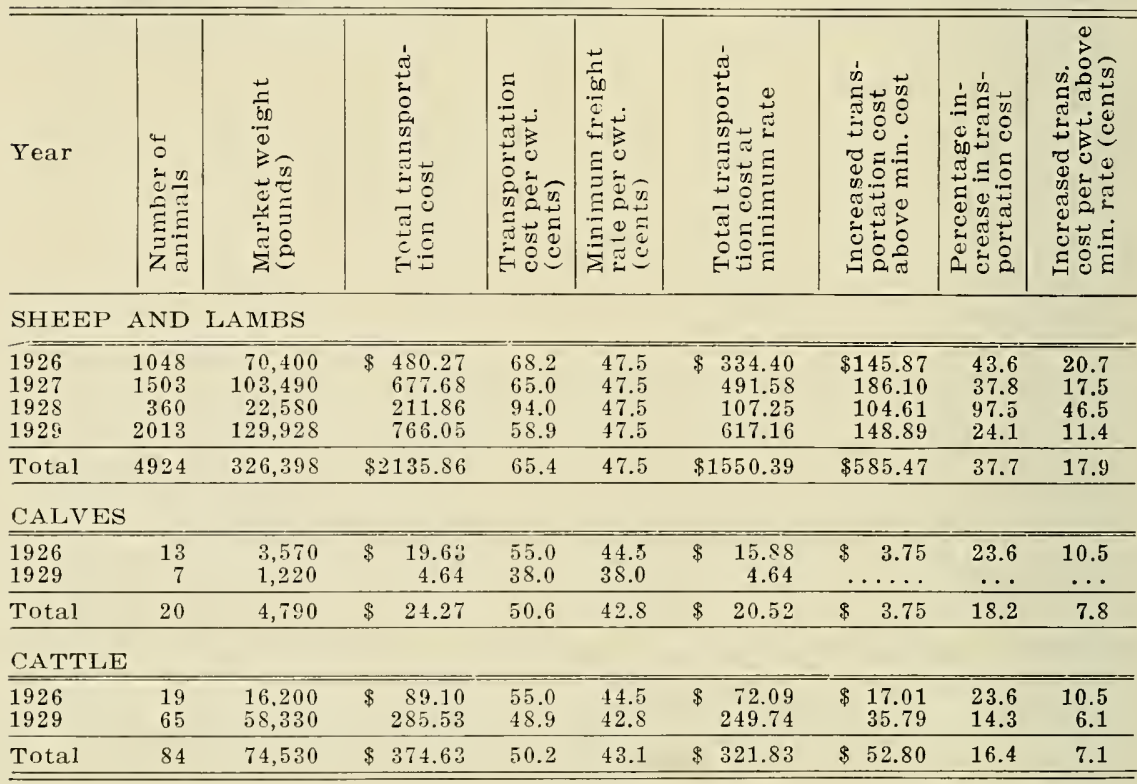




\section{The Wirt County Association}

Table 20 gives the transportation costs on livestock marketed by the Wirt county association.

For the Wirt association the transportation cost on sheep and lambs was increased 17.9 cents per cut., or 51.9 percent, above the minimum freight rate chiefly because of light loading, shipments by single deck, and mixed shipments of lambs and calves. The transportation cost for calves was increased 16.3 cents per cwt., or 47.5 percent, for the same reasons. A large percentage of the business of this association consisted of the marketing of lambs and calves

TABLE 20-Transportation costs on livestocli marlieted by the Wirt County Cooperative Livestock Shippers' Association, by years, comparca with costs if iivestock had been transported at minimum freight rates on raitroads

\begin{tabular}{|c|c|c|c|c|c|c|c|c|c|}
\hline Year & 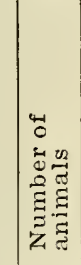 & 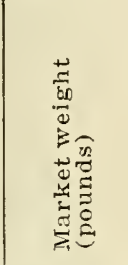 & 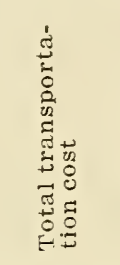 & 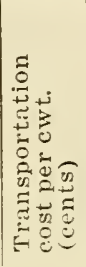 & 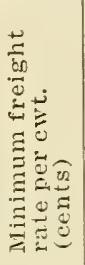 & 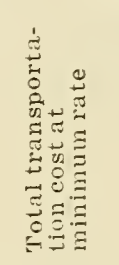 & 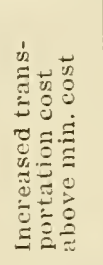 & 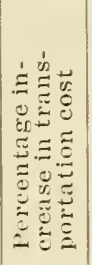 & 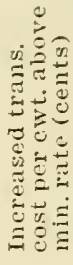 \\
\hline \multicolumn{10}{|c|}{ SHEEP AND LAMBS } \\
\hline$\overline{1925}$ & 981 & 62,170 & $\$ 294.21$ & 47.3 & 34.5 & $\$ 214.4 \mathrm{~S}$ & $\$ 79.73$ & 37.0 & 12.8 \\
\hline 1926 & 1058 & 66,420 & 383.04 & 57.6 & $31 . \overline{0}$ & 229.15 & 153.89 & 67.1 & 23.1 \\
\hline 1927 & 1163 & 73,270 & 373.97 & 51.0 & 34.5 & $252.7 \mathrm{~S}$ & 121.19 & 47.9 & 16.5 \\
\hline $192 \mathrm{~s}$ & 1075 & $64,7 \mathrm{so}$ & 369.76 & 57.0 & 34.5 & 223.49 & 146.27 & 65.0 & 22.5 \\
\hline 1929 & 1306 & $\$ 3,025$ & 412.37 & 49.6 & 34.5 & 286.44 & 125.93 & 43.9 & 15.1 \\
\hline Total & 5583 & 349,665 & $\$ 1833.35$ & 52.4 & 34.5 & $\$ 1206.34$ & $\$ 627.01$ & 51.9 & 17.9 \\
\hline \multicolumn{10}{|c|}{ CALVES } \\
\hline 1925 & 1012 & 167,775 & $\$ 752.82$ & 44.8 & 34.5 & $\$ 578.82$ & $\$ 17 \overline{4.00}$ & 30.0 & 10.3 \\
\hline 1926 & 595 & 96,437 & 518.71 & 53.7 & 34.5 & 332.71 & 186.00 & 55.9 & 19.2 \\
\hline 1927 & 289 & 50,625 & 297.99 & 58.8 & 34.5 & 174.66 & 123.33 & 70.6 & 24.3 \\
\hline $192 \mathrm{~s}$ & 472 & 80,720 & 429.36 & 53.2 & 34.5 & 278.48 & 150.88 & 54.0 & 18.7 \\
\hline 1929 & 401 & 70,255 & 372.08 & 52.9 & 34.5 & 242.38 & 129.70 & 53.5 & 18.4 \\
\hline Total & 2769 & 465,812 & $\$ 2370.96$ & 50.8 & 34.5 & $\$ 1607.05$ & $\$ 763.91$ & 47.5 & 16.3 \\
\hline \multicolumn{10}{|c|}{ CATTLE } \\
\hline$\overline{\overline{1925}}$ & 458 & $38 \overline{1,690}$ & $\$ 1427.01$ & 37.3 & 33.8 & $\$ 1290.93$ & $\$ 136.0 \mathrm{~s}$ & 10.5 & 3.5 \\
\hline 1926 & 274 & 203,510 & 780.17 & 38.3 & 34.5 & 702.11 & 78.06 & 11.1 & 3.8 \\
\hline 1927 & 35 & 31,580 & 151.34 & 47.9 & 34.5 & 108.95 & 42.39 & 38.9 & 13.4 \\
\hline 1928 & 94 & 82,650 & 301.43 & 36.5 & 34.5 & 285.14 & 16.29 & 5.7 & 2.0 \\
\hline 1929 & 128 & 108,655 & 415.92 & 38.2 & 34.5 & 374.86 & 41.06 & 10.9 & 3.7 \\
\hline Total & 989 & 808,085 & $\$ 3075.87$ & 38.0 & 34.1 & $\$ 2761.99$ & $\$ 313.88$ & 11.3 & 3.9 \\
\hline
\end{tabular}

and most of them were sent to market in mixed, single-deck shipments, thus adding materially to the transportation cost. A part of this increase undoubtedly was due to poor management, while a larger part may be attributed to the small volume handled by the association, coupled with its frequent shipments. The transportation cost on cattle was increased 3.9 cents per cut., or 11.3 percent, above the minimum freight rate by light loading and a few mixed shipments of cattle and lambs.

\section{The Roane County Association}

The transportation costs for livestock marketed by the Roane association are shown in Table 21. 
The average transportation cost for sheep and lambs marketed by the Roane association was 11.4 cents per cuvt., or 32.6 percent, above the minimum freight rate; for calves it was 17.1 cents per cwt., or 49 percent; and for cattle it was only 0.8 of a cent per cwt., or 2.2 percent, above. The increased cost on sheep and lambs was due primarily to light loadings; shipments by single deck; during the earlier years of the association an occasional mixed shipment of lambs and calves; and in later years to the practice of a combination of truck and boat transportation. The increased cost for transporting calves was due to light loads of mixed shipments of lambs and calves and also to the transportation by truck and boat referred to above. The slightly increased transportation cost for cattle was due to light loadings of mixed shipments.

TABLE 21-Transportation costs on livestock marketed by the Roane county association, by years, compared with costs if livestock had been transported at minimum freigltt rates on railroads

\begin{tabular}{|c|c|c|c|c|c|c|c|c|c|}
\hline Year & 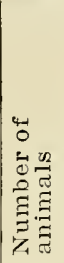 & 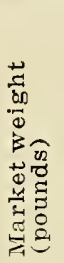 & 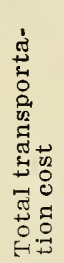 & 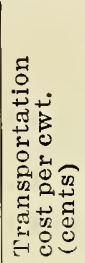 & 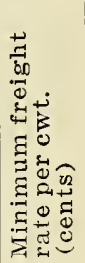 & 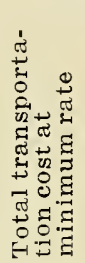 & 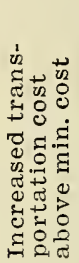 & 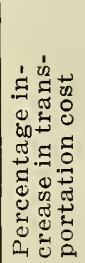 & 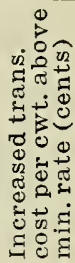 \\
\hline
\end{tabular}

\begin{tabular}{|c|c|c|c|c|c|c|c|c|c|c|}
\hline 1925 & & & & & & & & & & \\
\hline & 574 & $\begin{array}{r}3,150 \\
37000\end{array}$ & $\$$ & 14.72 & 46.3 & 35.0 & $\$ \quad 11.13$ & 3.59 & 32.3 & 11.3 \\
\hline 1927 & 483 & 31,600 & & $\begin{array}{l}161.43 \\
126.43\end{array}$ & 40.6 & 35.0 & $\begin{array}{l}129.50 \\
170.50\end{array}$ & $\begin{array}{l}31.93 \\
1589\end{array}$ & 24.7 & 8.6 \\
\hline $192 S$ & 983 & $5 S, S 20$ & & 302.25 & 51.3 & 35.0 & $\begin{array}{l}206.16 \\
206\end{array}$ & $\begin{array}{l}1.08 \\
96.09\end{array}$ & 46.6 & $\begin{array}{r}0.0 \\
16.3\end{array}$ \\
\hline 1929 & 1346 & 50,785 & & $376.8 \mathrm{~S}$ & 46.6 & 35.0 & 282.74 & 94.14 & 33.0 & 11.6 \\
\hline Total & 3430 & 211,385 & $\$$ & $9 S \overline{1.71}$ & 46.4 & 35.0 & $\$ 740.13$ & $\$ 241.58$ & 32.6 & 11.4 \\
\hline
\end{tabular}

CALVES

\begin{tabular}{lrrrrrrrrr}
\hline 1925 & 301 & 60,635 & $\$ 228.41$ & 37.7 & 35.0 & $\$ 212.22$ & $\$ 16.19$ & 7.6 & 2.7 \\
1926 & 379 & 67.545 & 268.08 & 39.7 & 35.0 & 236.41 & 31.67 & 13.4 & 4.7 \\
1927 & 73 & 13,210 & 67.97 & 51.5 & 35.0 & 46.24 & 21.73 & 47.0 & 18.5 \\
$192 \mathrm{~S}$ & 175 & 31,200 & 272.17 & 87.2 & 35.0 & 109.20 & 162.97 & 149.2 & 52.2 \\
1929 & 200 & 34,720 & 244.60 & 70.4 & 35.0 & 121.53 & 123.07 & 101.0 & 35.4 \\
\hline Total & 1128 & 207,310 & $\$ 1081.23$ & 52.1 & 35.0 & $\$ 725.60$ & $\$ 355.63$ & 49.0 & 17.1 \\
\hline
\end{tabular}

CATTLE

\begin{tabular}{lrrrrrrrrr}
\hline 1925 & 963 & $\$ 19,500$ & $\$ 2962.12$ & 36.1 & 35.0 & $\$ 2 S 69.30$ & $\$ 92.82$ & 3.2 & 1.1 \\
1926 & 742 & 681,550 & 2448.99 & 35.9 & 35.0 & 2385.42 & 63.57 & 2.7 & 0.9 \\
1927 & $\$ S$ & 86,000 & 301.00 & 35.0 & 35.0 & 301.00 & $\ldots 3.6$ & 3.7 & 0.6 \\
$192 S$ & 429 & 402,965 & 1436.83 & 35.6 & 35.0 & 1410.37 & 26.46 & 1.7 & 0.8 \\
1929 & 509 & 478,710 & 1679.59 & 35.8 & 35.0 & 1675.48 & 4.11 & 2.2 & 0.8 \\
\hline Total & 2731 & $2,469,025$ & $\$ 8828.53$ & 35.8 & 35.0 & $\$ 8641.57$ & $\$ 186.96$ & 2.2 & 0.8 \\
\hline \hline
\end{tabular}

It may be seen from Table 21 that the transportation cost on sheep, and especially on calves, increased markedly during 1928 and 1929. This large increase was due to the higher cost of truck and boat transportation, as compared with the cost by railroad. During the early part of the shipping season, when the volume was too small for carload shipments, the manager of this association transported calves and lambs by truck from Spencer to Parkersburg, a distance of 48 miles. They were then loaded on a boat which took them to 
the Pittsburgh marliet. This practice greatly increased the transportation cost. It is defender by the management, however, on the basis of the higher price which the producer received because of placing the animals on the market at their proper stage of development, and at a season when marliet prices are usually somewhat higher. Sufficient data are not available with which to prove or disprove this contention. The fact remains that a larger volume of business would permit the same service without this increase in transportation cost.

\section{The Barbour County Association}

Table 22 shows the transportation costs on livestock marketed by the Barbour association.

The records of only tivo years were available for the Barbour association, but for these years the transportation cost on sheep and lambs was 65.6 cents per cut., or 178.2 percent, above the minimum freight rate; for calves it was 75.9 cents per cwt., or 207.1 percent above; and for cattle 15.5 cents per cwt., or 42.4 percent above.

TABLE 22-Transportation costs on livestock marlicted by the Barbour connty association, by ycars, compared with cos's if livestocti lead been transnorted at minimum freight rates on railroads

\begin{tabular}{|c|c|c|c|c|c|c|c|c|c|}
\hline Year & 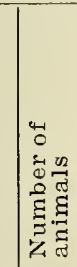 & 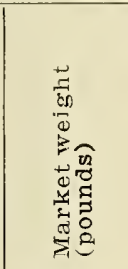 & 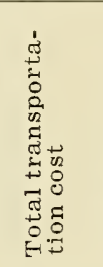 & 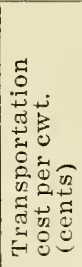 & 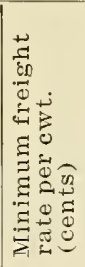 & 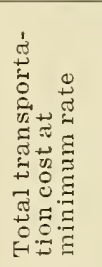 & 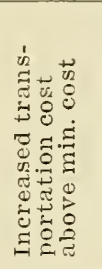 & 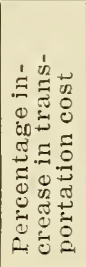 & 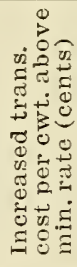 \\
\hline \multicolumn{10}{|c|}{ SHEEP AND LAMBS } \\
\hline$\overline{928}$ & 212 & 14,531 & $\$ 167.57$ & 115.3 & 36.5 & $\$ 53.03$ & $\$ 114.54$ & 216.0 & 78.8 \\
\hline 1929 & $61 \mathrm{~s}$ & 42,495 & 414.96 & 97.6 & 36.5 & 156.29 & 258.67 & 165.0 & 60.8 \\
\hline Total & 830 & $5 \overline{7,026}$ & $\$ 5 \$ 2.53$ & 102.1 & 36.5 & $\$ 209.32$ & $\$ 373.21$ & 178.2 & 65.6 \\
\hline \multicolumn{10}{|c|}{ CALVES } \\
\hline$\overline{1928}$ & 136 & 22,525 & $\$ 255.47$ & 113.4 & 36.5 & $\$ 82.21$ & $\$ 173.26$ & 210.0 & 76.9 \\
\hline 1929 & 161 & 23,880 & 266.26 & 111.4 & 36.5 & $\$ 7.66$ & 17 S. 60 & 203.0 & 74.7 \\
\hline Total & 297 & 46,405 & $\$ 521.73$ & 112.4 & 36.5 & $\$ 169.87$ & $\$ 351.86$ & 207.1 & 75.9 \\
\hline \multicolumn{10}{|c|}{ CATTLE } \\
\hline$\overline{1928}$ & 21 & $14,7 \mathrm{SO}$ & $\$ 70.94$ & 48.0 & 36.5 & $\$ 53.94$ & $\$ 17.00$ & 31.5 & 11.5 \\
\hline 1929 & 16 & 13,050 & 73.79 & 56.5 & 36.5 & 47.63 & 26.16 & 54.9 & 20.1 \\
\hline Total & 37 & 27,830 & $\$ 144.73$ & 52.0 & 36.5 & $\$ 101.57$ & $\$ 43.16$ & 42.4 & 15.5 \\
\hline
\end{tabular}

For a patron marketing 50 lambs of average weight through this association, if there were no other compensations, the loss due to this increased transportation cost would have been approximately $\$ 26$; for one marketing a 150-pound veal calf the loss would have been $\$ 1.14$; for one marketing a 1,000-pound steer the loss would have been $\$ 1.55$. Practically all of this increase in transportation cost may be attributed to shipments by truck. The county is situated approximately 150 miles from Pittsburgh, where the livestock was marketed. The management trucked practically all of the livestock 
to market during 1928 and 1929. The practice was also continued by this association during 1930 , and two or three of the other associations began it. The arguments used to justify the practice are: (1) convenience to farmer; (2) lower terminal market cost; (3) less shrink; (4) animals arrive in better shape; and (5) cost no more than by rail.

\section{Costs of Trucking Livestock to Market}

The practice of trucking to market has not been followed in West Virginia for a sufficient length of time to provide data with which to analyze these contentions, but it has been studied in other states. That transportation by truck is a convenience to producers, appears to be the only contention which is well founded in fact, and this convenience might well be provided at a lower cost by trucking the animals only to the railroad shipping point, then sending them on by rail. From data in Table $10 \mathrm{jt}$ is evident that there was a saving only in the item of feed cost for the Barbour association, and this saving was comparatively small.

A study of marketing livestock by truck in Ohio (4) indicates that transportation rates by truck were higher than freight rates into the Cleveland market and about the same as freight rates into the Cincinnati market; also, that buyers may discriminate against trucked-in livestock because of the unusual fill such animals often carry.

The report of a study of trucking livestock to market in Indiana (10) says: "With average figures, including all costs of the transportation of hogs from farm to market by each method, it seems that there would be a point somewhere between 30 and 90 miles at which the cost would be identical. Beyond this point it would become a question of how much the added convenience and flexibility of the truck are worth to the farmer in comparison to the railroad costs."

The following quotation taken from Minnesota "Farm Business Notes" (11) indicates the tentative conclusions concerning trucking costs in Minnesota: "In shipping by rail the farmer must assume the additional cost of transporting livestock from the farm to the shipping point. To hire this service from local truckers will cost on the average about ten cents per cwt. . . . . Furthermore, shipping by truck eliminates some of the local expenses of the shipping association or local buyer. The local expenses, including manager's salary, for cooperative shipping associations usually amount to at least eight cents per cwt. . . . . The terminal market charges of yardage and commission are higher for trucked-in livestock . . . . . Livestock arriving by truck are usually not fed at the terminal market, while on rail shipments there is the additional cost of feed. The rates of insurance against loss in transit are slightly lower for truck shipments than for rail shipments on distances up to 100 miles. No complete information is available on comparative shrinkage of livestock shipped by rail and truck." A table showing a comparison of 
truck and freight rates given in the Minnesota publication indicates that freight rates from the same points are consistently lower than truck rates.

The Iowa Agricultural Experiment Station has also given some attention to the growing practice of marketing livestock by truck in that state. Fitzgerald says (1):

"It is not difficult to see the advantages of trucking directly to market. It saves the farmer the time and tronble of getting the stock to the local shipping point, and returns are received more quickly. The former may be of great benefit to him, especially during the busy seasons of the year. The disadvantages of trucking are numerous and many of them are not so obvious. In the first place, hauling by truck is usually more expensive, often being three times as high as the cost by rail to the same market. Secondly, trucking engenders the feeling that no shrink is incurred, because the farmer usually has no home weight with which to check his market weight. Such information as is available tends to show that while shrink from trucked hogs is not as large as that received when the stock is shipped by rail, it is at least two-thirds as large. . . . .

"A third important disadvantage of the truck is the irresponsibility and carelessness of many of the private operators. In many cases they are operating on a 'shoe-string' and losses from accidents or carelessness cannot be collected even if it were legally possible to do so. At present no provision has been made for the control of these carriers or for making them responsible for the livestock while it is in their care. There has been considerable complaint, too, of mistakes made in the returns. Farmers are often paid for a smaller or larger number of hogs than they loaded on the truck, simply because the truck operator has not been careful in making out his returns. Another fact that the livestock shipper has to take into consideration is that the 'market', especially the local packers, usually discriminates against trucked hogs and pays 10 to 30 cents less for them than for carload lots of the same weight and quality, because of the gieater expense involved in handling and accounting for the smaller lots and because the packers have found that these hogs carry a larger fill and do not have as high dressing percentage."

Further study is necessary before a definite statement can be made as to the ultimate economy of trucking livestock to market. Results in other states indicate, however, that managers of West Virginia cooperative shipping associations may well be extremely cautious of adopting such a practice. Some associations in the state are trucking to the shipping point at a cost of about 10 cents per cwt. This service may well be expanded before resorting to trucking from farm to market.

\section{Summary of Transportation Costs}

The transportation cost on lambs and calves has been increased for all of the associations chiefly because of light loadings and mixed shipments. It is impossible to determine how much of this is due to poor management and how much to the small volume of business. A small volume of business undoubtedly gives rise to marketing practices which increase the transportation costs above the minimum available rate. Most of the managers are aware of this, but in attempting to render service to their patrons they are hampered by the small volume. As indicated earlier a part of the increased transportation cost on the lambs was due to the inability to load 
them up to the minnmum weight. By no means can all of the increase in transportation cost be attributed to this factor, for data presented in Table 12 show that the average weight of the loads was greatly below the minimum.

There appears to be a tendency for the increase in transportation cost to vary inversely with the number of animals shipped by the association. There is no clear correlation, because in some cases a manager will stop when he has one or two carloads and if he cannot obtain another full car he will not ship. This factor makes it possible for some of the associations with a small volume to transport their livestock to market as efficiently as an association with a larger volume. An association which attempts to ship at regular periods is the one whose transportation costs are most likely to be increased by its small volume. On the other hand, an association which ships the livestock of its members to market at the time the animals are best fitted to move may be rendering improved service which more than offsets the increased freight costs. The private dealer has an advantage over the cooperative in this respect because he can call for delivery of the livestock which he has purchased in sufficient quantities to load a car to the minimum weight.

The transportation cost is clearly affected by volume of business especially if the association attempts to put animals on the market at their proper stage of development. The volume of business of the shipping associations in West Virginia has been too small to realize the greatest economies in transportation and at the same time render the proper service to its patrons.

\section{TERMINAL MARKET COSTS}

Terminal market costs include charges for feed, yardage, insurance, and selling commission. The amount of these costs is largely beyond the control of the management of the cooperative shipping association. Yardage cost is on a per-head basis, and selling commission charges are based on the carload or on the head. In analyzing costs, however, comparison is easier if these are converted to a hundredweight basis.

The variations in terminal market costs between the associations as shown in Tables 8,9 , and 10 were due to differences in rates charged on the various markets; to a difference in the weight of animals marketed; and to the kind and weight of shipment: i. e., whether a straight or mixed shipment, and whether a light or heavy load.

\section{Feed Costs}

The average feed cost on sheep ranged from 0.4 of one cent per cwt. for the Barbour county association to 6 cents per cwt. for the Roane and Nicholas associations. The variations in this cost among the other associations were not great. The low feed cost for the Barbour association was due to the fact that practically all of its 
lambs were trucked and, therefore, not fed at the terminal market. This is one item that should be credited to the cost of transportation by truck. The saving, however, is small. Since the feed costs given in Table 8 are averages for a period of years, the varying price of feed caused a slight difference in the average feed cost per civt. in each association due to the fact that each unit did not have the same relative volume of business each year. However, the differences in the cost of this item arising from the circumstance were small. With the exception of the Barbour association the differences in feed costs were due primarily to the method of prorating expenses on mixed shipments. The expenses were prorated for each carload separately on a hundredweight basis. If lambs and calves were marketed in the same load the total market expense was divided by the total market weight of the load. Calves and lambs were then assessed at the same rate per cwt. When, therefore, calves were marketed with cattle, the feed cost assesserl to the calves was higher, and that to the cattle, lower than if they had been marketed in straight loads, because calves do not consume as much feed per cut. as do cattle.

The average feed cost of the various associations for calves ranged from 1 cent to 6 cents per cwt.; for cattle the range was from 5 cents to 7 cents; and for sheep and lambs it was from 0.4 of one cent to 6 cents. Feed cost is a minor part of the total marketing expense.

TABLE 23- Yardage rates on terminal markets to which TICst Virginia coopcrative livestock shipping associations send livestock

\begin{tabular}{l|c|c|c|c}
\hline $\begin{array}{l}\text { Kind of } \\
\text { animals }\end{array}$ & Jersey City & Pittsburgh & Baltimore & Lancaster \\
\hline Cattle & $\begin{array}{c}40 \text { centsper } \\
\text { head }\end{array}$ & $\begin{array}{c}33 \text { cents per } \\
\text { head }\end{array}$ & $\begin{array}{c}40 \text { cents per } \\
\text { head, } \\
\text { maximum } \$ 12 \\
\text { per car }\end{array}$ & $\begin{array}{c}\$ 1.25 \text { per head, } \\
\text { not to exceed } \\
\$ 30 \text { per car }\end{array}$ \\
Calves & $\begin{array}{c}20 \text { cents per } \\
\text { head }\end{array}$ & $\begin{array}{c}300 \text { pounds or } \\
\text { under, } 20 \\
\text { cents per head }\end{array}$ & $\begin{array}{c}20 \text { cents per } \\
\text { head, } \\
\text { maximum } \$ 20 \\
\text { per car }\end{array}$ & $\begin{array}{c}10 \text { cents per } \\
\text { head }\end{array}$ \\
\hline Sheep & $\begin{array}{c}\text { Scents per } \\
\text { head }\end{array}$ & $\begin{array}{c}\text { S centsper } \\
\text { head, } \\
\text { maximum } \$ 20 \\
\text { per car }\end{array}$ & 5 cents per \\
head
\end{tabular}

\section{Yardage}

The yardage rates charged on the terminal markets to which the cooperative associations shipped their livestock are shown in Table 23.

The Lancaster market had the lowest yardage rates on sheep and calves, while the Pittsburgh market had the lowest rate on cattle. The yardage costs shown in Tables 8 , 9, and 10 are on the basis of hundredweight rather than head, and are averages for all animals shipped by each association. The average yardage cost per cwt. on sheep and lambs ranged from 10 cents for three associations to 13 cents for one association; for cattle it ranged from 3 cents for two associations to 5 cents for three associations; and for calves 
from 3 cents for one association to 12 cents for two associations. Since yardage charges are based on the head, when they are converted to a hundredweight basis they will vary inversely with the weight of the animals. It is evident from yardage rates quoted in Table 22 that it is possible to decrease the yardage rates slightly on theBaltimore market by heavy loading, because there is a limit to the amount that may be charged per car. For instance, by loading more than 250 lambs in a car the rate would be decreased slightly because the maximum charge is $\$ 20$ per car, which is just equal to 250 head at 8 cents per head. There is no opportunity to make a large decrease in the rates, however. On the other markets there is no chance for reduction by heavy loading.

The average yardage costs per cwt. for each association as shown in the tables are not the same as would have been paid on straight shipments, since the costs shown are averages of the actual sums paid by the patrons who marketed through the cooperatives. Differences in the yardage cost in straight shipments and the cost actually paid by the patrons are due to the method of prorating expenses on mixed shipments. When cattle and calves are shipped together the yardage cost prorated to cattle is a bit higher than if they had been shipped alone. While the total yardage cost on the entire shipment is not increased, that part which the patron pays on cattle is slightly higher. When sheep and calves are shipped together, the yardage paid by the patron on sheep may also be slightly higher. The difference to the patron between the yardage cost on straight shipments and on mixed shipments was not great. Most patrons shipped some of each kind of animals and in the long run the differences between yardage cost in straight and mixed shipments may have about evened up. The difference between associations in the average cost per cwt. as shown in the tables was due to the different proportions of the cars which were mixed shipments; to the proportionate number and weight of the various kinds of animals in the mixed shipments that were marketed by the various associations; and to the difference in yardage rates of the various markets.

Since the yardage rates are based on the head, the number of animals in a car and the weight of the load have no effect on the total yardage cost, except in the case of the Baltimore market, where there is a maximum charge per car. This maximum is seldom exceeded. Neither management nor volume of business, therefore, affect the total cost of this item. But both poor management and small volume of business, when they result in mixed shipments, affect the proportion of the total yardage cost which each individual patron pays.

\section{Selling Commission}

The rates charged for selling livestock on the various markets to which the cooperative associations shipped are given in Table 24 .

Table 24 shows that the rate of the selling commission is on a somewhat different basis for each of the markets to which West Virginia associations shipped. On the Jersey City market, in the 
case of cattle, the sales value is a factor in determining the commission charged per head, but the commission is based entirely on the head for sheep and calves. There is no maximum limit per car for the selling commission on this market. On the Pittsburgh market the selling commission on all kinds of animals is based entirely on the head without reference to value, but with a maximum charge per car. On the Baltimore market, also, the selling commission for cattle is based on the head, but with a maximum charge per car which is higher than on the Pittshurgh market, while the commission on sheep and calves is based on the gross sales value, with no maximum charge per car.

TABLE 24-Selling commission rates on terminal marliets to which West Virginia cooperative livestock shipping associations ship livestock

\begin{tabular}{|c|c|c|c|}
\hline $\begin{array}{l}\text { Kind of } \\
\text { Animals }\end{array}$ & Jersey City & Pittsburgh ${ }^{1}$ & Baltimore 2 \\
\hline Cattle & $\begin{array}{l}\text { Sales value } \$ 20 \text { or } \\
\text { over, } \$ 1.25 \text { per head; } \\
\text { sales value under } \$ 20 \text {, } \\
75 \text { cents per head }\end{array}$ & $\begin{array}{l}\$ 1.25 \text { per head, not } \\
\text { to exceed } \$ 25 \\
\text { per car }\end{array}$ & $\begin{array}{c}\$ 1.25 \text { per head, not } \\
\text { to exceed } \$ 30 \\
\text { per car }\end{array}$ \\
\hline Calves & 30 cents per head & $\begin{array}{c}40 \text { cents per head, not } \\
\text { to exceed } \$ 15 \text { per } \\
\text { single deck and } \$ 28 \\
\text { per double deck }\end{array}$ & $\begin{array}{l}2 \text { percent on } \\
\text { gross sales }\end{array}$ \\
\hline Sheep & 15 cents per head & $\begin{array}{c}25 \text { cents per head, not } \\
\text { to exceed } \$ 15 \text { per } \\
\text { single deck and } \$ 25 \\
\text { per double deck }\end{array}$ & $\begin{array}{l}2 \text { percent on } \\
\text { gross sales }\end{array}$ \\
\hline
\end{tabular}

${ }^{1}$ Calves with sheep not to exceed $\$ 18$ per single deck. Calves with cattle not to exceed $\$ 28$ per car.

2Cows $\$ 1$ per head for those selling below $\$ 20$ per head.

The total charges for selling were prorated to the patrons of the association on the basis of hundredweight of animals shipped in the car. In the case of mixed shipments the same sort of analysis would apply to the selling commission costs as has been presented for yardage costs, with the rate paid by the patrons being affected by the method of prorating employed.

The average selling cost per cwt. on sheep which was charged to the patron ranged from 17 cents in the Roane county association to 30 cents in the Barbour association. Both the Barbour and Roane associations marketed their sheep and lambs on the Pittsburgh market. The large difference in selling cost was due to an increased rate for selling the trucked shipments of the Barbour association.

The average selling cost on calves ranged from 15 cents per cwt. for the Greenbrier and Pocahontas county associations to 27 cents for the Barbour association. On cattle the average selling cost ranged from 11 cents per cwt. for three associations to 17 cents for the Barbour association. The average selling cost for each association was shown in Table 8 .

With so many factors involved it is well-nigh impossible to explain what part of the variations in selling cost between the associations was due to a particular factor. The proportion of mixed shipments and the proportion of the different kind of animals in each 
mixed shipment; on some markets the weight of the animals and the total weight of the carload; and on some markets the value of the animals,-all affected the cost per cwt. which the patrons paid.

Small volume of business and poor management, resulting in mixed shipments, had no effect on the total amount of the sales commission charged except on the Pittsburgh market. On this market it is possible for a mixed shipment of calves and sheep to increase the selling commission $\$ 3$ per single deck and for calves shipped with catt'e to increase it by the same amount. (See Note 1, Table 24.) Trucking to this market will, however, greatly increase the total amount of the selling commission. For example, the typical truckload of lambs sent to market by the Barbour association contained 33 lambs. The selling commission amounted to 25 cents per head. The maximum charge for selling a doubledeck is $\$ 25$. The usual double deck shipped from West Virginia contains about 250 lambs. On this basis the selling commission amounts to 10 cents per head, or 15 cents per head less than on trucked-in lambs. For lambs weighing 75 pounds at the market, there is a difference then of approximately 20 cents per cwt. In the same manner, trucking to the Pittsburgh market increases the total selling commission on calves.

Livestock shipped by the cooperative associations to the Pittsburgh market was sold by the Producers Cooperative Commission Association, of which The West Virginia Cooperative Livestock Shipping Association, Inc., is a member. Practically all of the livestock shipped by the Barbour, Jackson, Roane, and Wirt county associations, and a part of that by the Harrison and Braxton county associations, went to this market, while that from the other associations was sold on the Baltimore, Lancaster, or Jersey City markets. There were no cooperative commission firms on these latter markets. Some of the private commission merchants made an extra charge of 25 cents per shipper for prorating the terminal market expenses. These charges were included in the calculations of the commission charges.

\section{HOME EXPENSES}

Home expenses include charges for "insurance fund", manager's commission, and local car expense. An analysis of these costs for each association is presented below.

\section{Insurance Fund}

The rate of insurance fund authorized by each association is shown in Table 25.

The insurance fund rate is not the same for all of the associations. The rate is fixed by the board of directors of each county association, but on the advice of the state association it is kept more or less uniform. Not all managers assessed the full amount of the rate permitted by the association. As shown in Table 25, the insurance fund varies with the ownership of the shipment, whether 
one or more patrons own the animals in the shipment. The rate actually charged the patron may be somewhat different from the rate authorized because of the method used for prorating the expenses of mixed shipments. The average insurance fund rates per cwt. collected by the associations are shown in Tables 8, 9, and 10 . The average rate collected on sheep and lambs ranged from 2 cents per cwt. for the Greenbrier county association to 12 cents per cwt. for the Barbour association; on calves the range was from 2 cents charged by the Greenbrier association to 9 cents by the Barbour association; and on cattle from 1 cent collected by the Greenbrier association to 9 cents by the Barbour association. The average rate collected by the other associations was between these extremes.

Money collected as insurance fund constituted the larger part of the gross income; in fact the entire gross income of most of the associations. Occasionally, due to inaccurate calculations, there was a slight gain in prorating which added to the income of the association. The Wirt association charged 10 cents per cut. for marketing the livestock of non-Farm Bureau members, as well as a small weigh fee, which also added to its income.

TABLE 25-Rate of insurance fund authorized by boards of directors of cooperative shipping associations, by counties, 1929

\begin{tabular}{|c|c|c|c|c|c|c|}
\hline \multirow[b]{2}{*}{$\begin{array}{c}\text { County } \\
\text { association }\end{array}$} & \multicolumn{2}{|c|}{ CATTLE } & \multicolumn{2}{|c|}{ CALVES } & \multirow{2}{*}{ 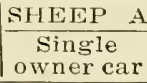 } & \multirow{2}{*}{$\begin{array}{l}\text { JD LAMBS } \\
\text { Multiple } \\
\text { owner car }\end{array}$} \\
\hline & $\begin{array}{c}\text { Single } \\
\text { owner car }\end{array}$ & $\mid \begin{array}{c}\text { MuItiple } \\
\text { owner car }\end{array}$ & $\begin{array}{c}\text { Single } \\
\text { owner car }\end{array}$ & $\begin{array}{l}\text { Multiple } \\
\text { owner car }\end{array}$ & & \\
\hline & $\begin{array}{l}\text { (Cents per } \\
\text { cuot.) }\end{array}$ & $\begin{array}{l}\text { (Cents per } \\
\text { covt.) }\end{array}$ & $\begin{array}{l}\text { (Centsper } \\
\text { cwt.) }\end{array}$ & $\begin{array}{c}\text { (Cents per } \\
\text { cwt.) }\end{array}$ & $\begin{array}{c}\text { (Cents per } \\
\text { cwot.) }\end{array}$ & $\begin{array}{c}\text { (Cents per } \\
\text { cwt.) }\end{array}$ \\
\hline Barbour & 5 & 6 & 5 & 6 & 5 & 6 \\
\hline Braxton & 5 & 6 & 5 & 6 & 5 & 6 \\
\hline Greenbrier & 2 & 2 & 2 & 2 & 2 & 2 \\
\hline Harrison & 5 & 6 & 5 & 6 & 5 & 6 \\
\hline Jackson & 5 & 6 & 5 & 6 & 5 & 6 \\
\hline Nicholas & 5 & 6 & 5 & 6 & 5 & 6 \\
\hline Pocahontas & 5 & 5 & 5 & 5 & 5 & 5 \\
\hline Roane & 3 & 6 & 3 & 6 & 3 & 6 \\
\hline Wirt & 5 & 5 & 5 & 5 & 5 & 5 \\
\hline
\end{tabular}

For the most part, however, the operating expenses of the cooperative associations were paid out of insurance fund collections. The manager is supposed to pay the full amount of the insurance fund to the treasurer of the association as soon as the account for each shipment is closed. Unfortunately, the treasurers of most of the associations have kept such meager and unintelligible records that it was impossible to analyze the expenditures of this fund. Many records have been lost entirely. While the by-laws of the associations authorize an annual audit of both the manager's and treasurer's accounts, in most instances the treasurers have failed to submit an account that could be audited.

The following items of expense were the common ones which were paid out of the insurance fund: (1) to the state association, dues of 1 cent per civt. on all livestock marketed; (2) payments for loss due to death or injury of animals while in transit; (3) payments for stationery, scale books, postage, and other current operating ex- 
penses; (4) payments for losses in prorating; (5) payments for directors' meetings of county and state associations. Such payments constitute the bulk of the expenses of the association. A few associations have made contributions to assist the state association in livestock improvement work, and some associations have paid patronage dividends, which came out of the insurance fund.

A partial list of patronage dividends which have been paid by county associations is shown in Table 26. This may not be a complete list, but it does constitute the bulk of the patronage dividends which have been returned by the associations.

TABLE 26-Patronage dividend payments

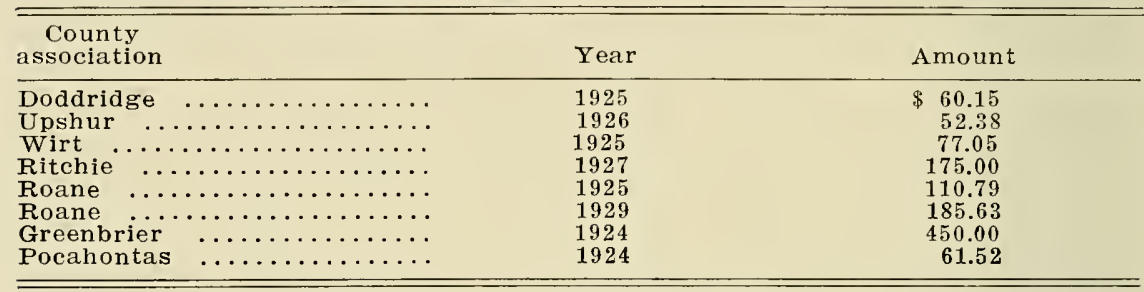

If this list is reasonably accurate there is evidence that in recent years the expenses of the associations have consumed most of the money collected as insurance fund. Because of the lack of sufficient data it is impossib'e to analyze the cause of this circumstance. The associations should be careful to keep their operating expenses reasonable and wherever possible return a patronage dividend, even though it be a small one. With the exception of payments for directors' meetings, the operating expenses are of such a nature that they should vary directly with the volume of business.

From the few data available it appears as though not more than ten percent of the insurance fund collections was paid to patrons for dead and injured animals.

\section{Local Car Expense}

The average of local car expense on sheep and lambs varied from nothing in the Greenbrier county association to 12 cents per cwt. in the Braxton association; on cattle it varied from nothing in the Greenbrier and Pocahontas associations to 4 cents in the Harrison association; and on calves from nothing, again in the Greenbrier and Pocahontas associations, to 5 cents in the Roane association. The average local car expense per cwt. for each association and for each kind of animals is shown in Tables 8, 9, and 10, from which it may be observed that there was a wide variation in this expense between the associations. As a rule the cost of rope and partitions was charged to the account of local car expense. Some associations charged costs of driving to the local car expense account, while in other associations each patron was responsible for the delivery of his animals to the shipping point. Whenever partitions are required for mixed shipments the local car expense is increased, and this was 
the cause of the comparatively large "local car expense" of some associations. In these cases small volume, resulting in mixed shipments, added to the charges designated as local car expense.

3. Manager's Commission

The rate of the manager's commission as authorized by the various associations is shown in Table 27.

As shown in Tables 8, 9, and 10, respectively, the average amount of manager's commission collected per cwt. on sheep and lambs ranged from 7 cents in the Greenbrier association to 14 cents in the Braxton and Jackson associations; on cattle it ranged from 5 cents in the Jackson association to 10 cents in the W Wirt association; and on calves it ranged from 7 cents in the Braxton association to 11 cents in the Barbour association. The differences between associations in the average amount per civt. collected as manager's commission were due to: (1) a difference in the rates anthorizerl by the board of directors; (2) a difference in the proportion of single ownership shipments; (3) a difference in the proportion of mixed shipments and kind of mixed shipments; and (4) the fact that some managers did not always charge the full commission rate authorized.

TABLE 27-Rate of manager's commission authorized by boards of directors of cooperative shipping associations, by counties, 1929

\begin{tabular}{|c|c|c|c|c|c|c|}
\hline \multirow{2}{*}{$\begin{array}{c}\text { County } \\
\text { association }\end{array}$} & \multicolumn{2}{|c|}{ CATTLE } & \multicolumn{2}{|c|}{ CALVES } & \multicolumn{2}{|c|}{ SHEEP AND LAMBS } \\
\hline & $\begin{array}{c}\text { Single } \\
\text { owner car }\end{array}$ & $\begin{array}{l}\text { Multiple } \\
\text { owner car }\end{array}$ & $\begin{array}{c}\text { Single } \\
\text { owner car }\end{array}$ & $\begin{array}{l}\text { Multiple } \\
\text { owner car }\end{array}$ & $\begin{array}{c}\text { Single } \\
\text { owner car }\end{array}$ & $\begin{array}{l}\text { Multiple } \\
\text { owner car }\end{array}$ \\
\hline & $\begin{array}{l}\text { (Cents per } \\
\text { cwt.) }\end{array}$ & $\begin{array}{c}\text { (Cents per } \\
\text { cwot.) }\end{array}$ & $\begin{array}{l}\text { (cents per } \\
\text { coot.) }\end{array}$ & $\begin{array}{c}\text { (cents per } \\
\text { curt.) }\end{array}$ & $\begin{array}{l}\text { (Cents per } \\
\text { crot.) }\end{array}$ & $\begin{array}{l}\text { (Cents per } \\
\text { cwt.) }\end{array}$ \\
\hline Barbour & 5 & 10 & 5 & 10 & 7 & 14 \\
\hline Braxton & 5 & 10 & 5 & 10 & $\dot{s}$ & 15 \\
\hline Greenbrier & 5 & 10 & 5 & 10 & 5 & 10 \\
\hline Harrison & 5 & 10 & 5 & 10 & 7 & 14 \\
\hline Jackson & 5 & 10 & 5 & 10 & 7 & 14 \\
\hline Nicholas & 5 & 10 & 5 & 10 & 7 & 14 \\
\hline Pocahontas & 5 & 10 & 5 & 10 & 8 & 15 \\
\hline Roane & 5 & 10 & 5 & 10 & 7 & 14 \\
\hline Wirt & 5 & 10 & 5 & 10 & 5 & 10 \\
\hline
\end{tabular}

Managers of West Virginia cooperative livestock shipping associations are paid entirely on the basis of hundredweight of livestock sold by the association. The total amount of their pay, therefore, varies directly with their volume of business. There is little uniformity among such cooperatives in the United States in the methods of paying their managers, but payment on the hundredweight basis appears to be the most common practice. Of $115 \mathrm{co}-$ operative associations reporting to a questionnaire in Minnesota (2), 103 were paying the managers on the basis of hundredweight of livestock shipped; all but 2 of these were paying the same rate for all species of livestock shipped. The rates in 1919 ranged from 5 to 15 cents, with 68 percent of the associations paying from 6 to 8 cents. Seven of the 115 associations were paying by the carload, the amount ranging from $\$ 15$ to $\$ 18$. Two associations were paying their managers $\$ 150$ per month and one association was paying $\$ 5$ per day. Of the 71 associations for which manager's earnings were 
given, only 45 percent of the managers received less than $\$ 1,000$ per year.

In Iowa "the average manager's fee in those associations in which the manager does all the prorating was, in 1925, 5.7 cents per cuvt.; in the associations in which the manager prorates the home expense only, 5.7 cents; in the associations in which the manager does not prorate, 5.6 cents per hundredweight." (1)

In Wisconsin "the commonest payments are 6 cents, 8 cents, or 10 cents a hundredweight for all classes alike." (6) Some associations, however, pay on a car basis, and others on an hour, day, or month basis.

In Ohio the manager receives a commission of 8 to 12 cents per cwt. on livestock shipped. (9)

It appears that the rate of the manager's commission is a bit higher for the West Virginia associations than for associations in some other states. But the rate for the West Virginia associations does not appear to be too high in view of the fact that managers do all of the prorating and that most of the shipments are made up of small lots of several owners.

\section{THE MANAGER}

It is generally recognized that the quality of the management is of vital importance to the success of any cooperative association. Hibbard and co-authors state very clearly the value of good management (5):

"A good manager is necessary. His efficiency or inefficiency may result in the saving or loss to the association of an amount many times the salary he receives. Unless a man can be secured who has the necessary energy, ability, experience, and time to devote himself to the job, and unless that man has the intelligence to read and understand market reports, to advise the members of the association as to the best time to ship and to educate the members in business principles of marketing, the association will not last long. Livestock commission firms are almost of one accord in the belief that success or failure depends to the extent of 90 percent on a competent manager. When such a man is found he should be paid enough to make it worth his while to devote his attention to the position he holds ..... A competent manager will keep down the losses in transit due to deaths, cripples, and heavy shrinkages, and will earn his salary many times over.

"There are advantages and disadvantages in hiring for manager a man who has been an independent shipper. No doubt he knows nuch about the business, but he will many times be distrusted by the members. Such men often have little faith in cooperation, and may have a motive in seeing it fail."

The problem of obtaining good management is a major one for West Virginia cooperative shipping associations. In each county are men well qualified to do the work if they were willing to undertake it. Several of the associations have been fortunate in procuring capable and sympathetic management; others have failed utterly. There are several reasons why it is difficult to secure good management in the state. The volume of business in all of the counties 
is necessarily small. Even though the association marketed all the livestock, still the volume would not erfual that of some of the local associations in Iowa, Minnesota, or several other states, where there is a great concentration of livestock. Up to the present, however, the limited volume has been still further limited decidedly by the competition of independent dealers through their methods of "tieing up" the livestock by contract, small loans, agreement to re-purchase livestock, etc. The small volume of business $i n$ sight is a handicap to securing good management. But in several counties, if a manager could market one-half or two-thirds of the livestock, he would have an income of from two to three thousand dollars for the marketing season.

A second reason why it is difficult to get capable management is that most of those who are capable are already trading on their own account and are not interested in cooperative marketing. There is a mania for trading in livestock in this state and it seems as though a large part of the better farmers are more or less engaged in it. Several associations have been unfortunate in their employment of managers who continued to buy and sell on their own account while managing the association. Some associations in the state undoubtedly owe their demise to this practice on the part of their manager.

The importance of good management to the success of shipping associations in West Virginia is well illustrated by the history of two of the county associations. From its organization until 1929 an association which may be designated as Association A was one of the strong ones in the state, ranking near the top in volume of business. The manager was capable, active, and interested in the work. At the end of the 1928 shipping season he moved from the state to enter other work. A new manager was selected for 1929. During that season the volume of business decreased to about three carloads. For 1930 another manager was selected, but no shipments were made.

When first organized, another group, designated here as Association $B$, was fortunate in obtaining a capable and interested manager. This man had been an independent dealer but became interested in cooperative shipping. He soon built up the association until it stood near the top of all associations in volume. Because of other interests he gave up the managership of the shipping association about 1926, when another manager was selected. This manager was sufficiently interested but lacked ability and was handicapped by poor health. The volume of business of this association rapidly decreased. Records were so poorly kept that it was impossible to include this association in the present study. At the end of the 1929 season this manager was released and the former manager again took over the affairs of the association in 1930 . During that year the volume of business of the association increased until it was the largest in the state. There seems little doubt that the quality of management is the most important single factor in the success of cooperative shipping associations in West Virginia. 
It is one of the duties of the manager to prorate the expenses of marketing. The expenses of each carload are prorated separately. The total expense is divided by the market weight and prorated to the patrons on the basis of hundredweight shipped. Some inequalities arise from this method, chief of which is the increase in marketing cost which a patron must pay if he happens to ship in a carload weighing less than the minimum. Mixed shipments, as indicated earlier, cause some small inequalities in marketing costs.

The Wirt county association has been using the "flat-rate" prorating method for the past few years. By this method one charge covers all expenses and there is no variation if a man ship either in a light or mixed car. Undoubtedly there is less injustice and less work in prorating by this method, but the difficult part is to establish the flat-rate which will just about cover the expenses for the shipping season.

\section{LOSSES IN TRANSIT FROM DEATH AND CRIPPLES}

It was not possible to summarize the amount of loss due to death and cripples because of the inadequacy of records which have been kept of such loss. The association pays the patron the appraised market value of the injured animals. These payments are made from the insurance fund.

The report (3) of a study of losses in shipping Ohio livestock contains certain conclusions which, because of the similarity of marketing conditions in the two states, appear to be at least partially applicable to West Virginia livestock shipping.

The study indicates that for sheep, single decks will show a higher loss for cripples and deads than will double decks. There was no outstanding difference between single decks and double decks in the cripple loss on calves, but with dead calves the ioss in single decks was much higher.

In nine months of the year the number of dead sheep taken from cars was greater in partitioned than in unpartitioned cars. The loss was slightly higher for the unpartitioned cars during October, July, and August. Crippling was greater with sheep in partitioned cars for all months of the year except April and May. when the loss was about the same as in unpartitioned cars. With cattle and calves no outstanding differences in losses were found between partitioned and unpartitioned cars.

More sheep were crippled in mixed than in straight decks. The mixed single decks showed a much higher loss from crippled sheep than straight singles, while there was but little difference between straight and mixed double decks. The death rate of sheep showed that the losses were consistently much higher in mixed than in straight loads, and the single decks in practically all cars showed a larger difference in losses between straight and mixed loads than did the double decks. 
The outstanding variations of losses by agencies shipping were for dead sheep and hogs. In both instances the cooperatives seemed to have a much higher loss at particular seasons of the year, i. e., December, January, February, March, June, and September. while the losses were about the same for both the cooperative and independent shipper during the other months.

Of course it may not be strictly accurate to take the above conclusions and apply them bodily to shipping under West Virginia conditions. As has been shown, much of the livestock was marketed by the West Virginia cooperative associations in single deck and mixed shipments. The Ohio study indicates that shipping in this way results in larger losses than by shipping in double deck and straight loads. Unfortunately, the data for West Virginia cooperative shipments are too meagre to shed any light on the subject, but the Ohio study gives reason to believe that the losses sustained by the associations were greater than they would have been in double deck and straight car shipments.

TABLE 28-Average percentage shrink, total home weight, market weight, and years on which based, by cooperative association and lind of animals

\begin{tabular}{|c|c|c|c|c|c|}
\hline County & Years & Kind & $\begin{array}{c}\text { Home } \\
\text { weight }\end{array}$ & $\begin{array}{l}\text { Market } \\
\text { weight }\end{array}$ & $\begin{array}{l}\text { P'ercentage } \\
\text { shrink }\end{array}$ \\
\hline Barbour & 1928 & $\begin{array}{l}\text { Cattle } \\
\text { Calves } \\
\text { Lambs }\end{array}$ & $\begin{array}{l}16,160 \\
23,765 \\
18,490\end{array}$ & $\begin{array}{l}14,780 \\
21,875 \\
16,955\end{array}$ & $\begin{array}{l}\$ .5 \\
8.0 \\
8.3\end{array}$ \\
\hline Braxton & $1927,28, ' 29$ & $\begin{array}{l}\text { Cattle } \\
\text { Calves } \\
\text { Lambs }\end{array}$ & $\begin{array}{r}233,864 \\
45,456 \\
461,950\end{array}$ & $\begin{array}{r}220,308 \\
43,020 \\
410,616\end{array}$ & $\begin{array}{r}5.8 \\
5.4 \\
11.1\end{array}$ \\
\hline Greenbrier & $\begin{array}{l}1923, ' 24, ' 25, \\
26,27,28,29\end{array}$ & $\begin{array}{l}\text { Cattle } \\
\text { Calves } \\
\text { Lambs }\end{array}$ & $\begin{array}{r}348,855 \\
1,365 \\
353,762 \\
\end{array}$ & $\begin{array}{r}328,880 \\
1,330 \\
313,554 \\
\end{array}$ & $\begin{array}{r}5.7 \\
2.6 \\
11.4 \\
\end{array}$ \\
\hline Harrison & $\begin{array}{l}1925,,^{\prime} 6, ' 27, \\
228,29\end{array}$ & $\begin{array}{l}\text { Cattle } \\
\text { CaIves } \\
\text { Lambs }\end{array}$ & $\begin{array}{r}635,624 \\
2,187 \\
300,075 \\
\end{array}$ & $\begin{array}{r}597,567 \\
2,052 \\
263,703 \\
\end{array}$ & $\begin{array}{r}6.0 \\
6.2 \\
12.1 \\
\end{array}$ \\
\hline Jackson & 1929 & Lambs & 35,084 & 31,233 & 11.0 \\
\hline Nicholas & 1928,29 & Lambs & 122,136 & 106,058 & 13.2 \\
\hline Pocahontas & 1926,229 & $\begin{array}{l}\text { Cattle } \\
\text { Calves } \\
\text { Lambs }\end{array}$ & $\begin{array}{r}79,559 \\
5,296 \\
361,182 \\
\end{array}$ & $\begin{array}{r}73,120 \\
4,685 \\
318,136 \\
\end{array}$ & $\begin{array}{r}8.1 \\
11.5 \\
11.9\end{array}$ \\
\hline Roane & $\begin{array}{l}1925, ' 26, ' 27, \\
, 28,29\end{array}$ & $\begin{array}{l}\text { Cattle } \\
\text { Calves } \\
\text { Lambs }\end{array}$ & $\begin{array}{r}1,411,072 \\
55,931 \\
204,388 \\
\end{array}$ & $\begin{array}{r}1,313,463 \\
50,925 \\
-180,122 \\
\end{array}$ & $\begin{array}{r}6.9 \\
9.0 \\
11.9 \\
\end{array}$ \\
\hline Wirt & $\begin{array}{l}1925,26,: 27 \text {, } \\
28,29\end{array}$ & $\begin{array}{l}\text { Cattle } \\
\text { Calves } \\
\text { Lambs }\end{array}$ & $\begin{array}{l}479,937 \\
368,931 \\
321,261\end{array}$ & $\begin{array}{l}458,851 \\
353,717 \\
303,136\end{array}$ & $\begin{array}{l}4.4 \\
4.1 \\
5.6\end{array}$ \\
\hline
\end{tabular}

\section{SHRINKAGE}

Shrinkage constitutes one of the major losses in shipping livestock. The average shrink for various kinds of animals and for various associations is shown in Table 28. It is beyond the scope of this study to investigate the causes of variations in shrinkage, and methods of keeping such at a minimum. The average shrinkage 
shown in the table was determined from calculations based on the records of the various associations included in the study, and was calculated for use in the price comparisons which have been made.

\section{Independent Dealers' and Cooperative Prices Compared}

\section{PRELIMINARY CONSIDERATIONS}

The amount of profit earned in relation to capital investment is the best measure of the efficiency of an independent business enterprise. This measure cannot be applied to a cooperative shipping association, since it is a non-profit organization. The purpose of a cooperative is to obtain not only for its patrons but also for all livestock farmers in the state the highest possible net returns on their livestock enterprises. Several factors contribute to the accomplishment of such a purpose: The association must seek to obtain the highest sales price possible for the quality of livestock it is marketing. To this end there must be a careful study of the different markets so as to put the animals on the particular market at the particular time when they will bring the highest price. Not only must the association seek to obtain the highest possible price; it must also do the marketing as cheaply as is possible in keeping with the service afforded. The association having the lowest marketing cost is not necessarily the most efficient one, because both the price received and the quality of the service rendered may be of a lower order. The association must seek to improve the quality of the livestock of the state, because an improvement in quality is a means of obtaining higher net returns. The association does not necessarily have to handle all the livestock to increase the net returns to the producers. It may force competitors to follow practices which will result in higher net returns to the producer.

It has not been possible to ascertain if the associations have always sold the livestock offered by patrons at the highest price possible to obtain for the given quality. So many factors are involved that, with limited data, analysis and proof are well nigh impossible. The quality of the animals figures largely in price, but quality cannot be accurately recorded. The supply of certain qualities offered on a market at a given time affects the price and only in a general way are such data recorded. The actual sale of livestock on the terminal market is made by an agent of the shipper rather than by the shipper himself. The terminal market price depends somewhat on the selling ability of the agent and is, therefore, partly beyond any control of the local shipper. The local shipper however does have something to do with the terminal price even though he does not do the actual selling. He selects the agent to sell for him and the wise choice of an agent may mean a consistently better price. Many of the cooperative associations in West Virginia sell through the Producers' Cooperative Commission Association in Pittsburgh, but freight differentials and market condi- 
tions make it desirable for other of the associations to sell on the eastern markets. There are no cooperative commission associations on these markets and each association manager is left to select an independent commission firm to make his sales.

The local shipper has an opportunity to affect the terminal market price by selecting the time to put the livestock on the market, and to a more limited extent in the selection of the terminal market to which he ships. He also affects the terminal market price to a degree by having some influence on the condition in which the livestock arrives on the market.

There is reason to believe, however, that cooperative shipping associations in this state have not always received the highest price their livestock would have brought if marketed under different conditions. The manager is limited by small volume in his ability to ship animals to the proper market at the proper time. And the associations have not all been fortunate in obtaining the services of a manager competent to sell consistently near the top of the market for the quality offered. The first step toward changing these conditions is an increase in volume.

There is a fast-growing tendency in West Virginia to consider the function of a cooperative shipping association to be only to provide competition to an independent dealer. But competition means little unless the plane of competition is known. If the local competition can be raised to a high plane, the producer will receive greater returns than if the competition were on a lower plane. The plane of competition cannot be raised to the point where it should be until conditions are such that the cooperative sells its livestock at the highest possible price. Larger volume and better management, which is always hampered by small volume, are very important factors in raising this plane of competition.

In the analysis of the marketing costs of cooperative associations it has been shown that while costs are not excessive there is room to reduce them materially in most of the associations. Again a larger volume and better management are the key to reducing the marketing costs.

In some respects the cooperatives do not give their patrons as good service as the independent dealers. As a rule the dealer takes up the animals at the farm of the owner, while the patron of the shipping association must deliver his stock to the shipping point.

It has long been the custom in this state to drive livestock over the public roads to the shipping point. The development of hardsurfaced roads with the accompanying heavy motor traffic has made it dangerous, annoying, and in some sections practically impossible to move animals on foot to the shipping point. Few farmers are equipped with trucks, and to hire one means considerable expense. There appears to be an opportunity for cooperative associations to improve greatly the service, without a corresponding increase in cost, by trucking livestock from farm to shipping point. 
In another respect the service of the cooperative is not so good as that given by the independent dealer, that is, in financing the livestock producer. As has been explained earlier, the dealer obtains a considerable part of his volume through his various livestock financing operations. Of course it is beyond the field of the cooperatives to make advances to producers as the dealers do, but the opportunities of financing livestock production offered through the Federal Farm Board have not yet been seized by the cooperatives.

The shipping associations in cooperation with the Agricultural Extension Division and the agricultural agents of the Baltimore and Ohio and the Chesapeake and Ohio Railroads have done much to improve the quality of livestock in West Virginia. This is especially true in the case of lambs. In 1926 these agencies began a lamb improvement campaign in the state looking toward the production of better quality market lamb. The campaign was first carried on in twenty of the better lamb-producing counties but since that time has been expanded to include 24 counties. From 1926 to 1930 approximately 21,000 lambs were docked and castrated at 923 different field meetings and demonstrations attended by 9,730 farmers. The campaigns also have emphasized the practice of treating for internal and external parasites, and this practice is fast becoming common. A large proportion of the lambs produced in the state are now docked and castrated, with the result that it has become common for West Virginia lambs to top the markets upon which they are sold. During the five years in which the cooperating agencies referred to above have operated the so-called "Purebred Ram Special", 914 purebred rams have been sold to farmers to head their flocks.

This improvement work was started around the cooperative shipping association. Because of the fact that it sold lambs on the basis of quality, the existence of the shipping associations has made an extension of this improvement possible. In earlier years it was customary for independent dealers to discourage the practice by making a price discrimination against docked and castrated lambs. Work toward the improvement of the quality of cattle has scarcely begun, but this provides a wide field of service for the cooperative associations and the agencies cooperating with them.

It has not been possible to compare the marketing costs of the cooperative associations with those of independent dealers, since a dealer's expenses are made up of numerous non-comparable items, and none could be found who pretended to keep any sort of adequate record of them. It has been possible, however, to make a fairly satisfactory comparison of the net price received by the patrons of cooperatives with prices paid by the independent dealers during 1928 and 1929.

Because of the varying quality of the animals and the varying times of sales, there are many pitfalls in a comparison of prices. Large numbers have been depended on to even up these variations to some extent. A personal knowledge of the conditions in the var- 
ious counties permits the writer to say that there were no great variations in the quality of lambs or in the time of marketing between the independent dealers and the cooperative associations. There was, however, considerable difference in the quality of cattle marketed by the two agencies. A questionnaire sent to commission merchants who handled the livestock of both agencies, and to county. agricultural agents who are familiar with the livestock in their connties, brought the uniform reply that, on the whole, the average quality of lambs marketed by the cooperative associations was somewhat higher than of those marketed by independent dealers, but that the average quality of the cattle marketed by the former was in most counties below that of the latter. Those cooperative associations which marketed cattle sold some of the best cattle in their respective counties, but such cattle did not form as large a proportion of their total marketings as was the case with many independent dealers.

In the early days of cooperative livestock marketing in West Virginia as well as in other states, farmers were induced to patronize the shipping association on the argument that they would receive a higher price for their animals than their neighbor, who sold to an independent dealer. The argument, which was probably true at that time, was that the independent dealer was selling on the same market as the cooperative, was taking a wider margin than the cost of marketing through the cooperative, and therefore could not pay the producer as much for his animals as he would receive by selling through the association.

Even yet farmers are prone to judge the association wholly on a comparison of prices. If the independent dealer pays as much or more than can be obtained through the cooperative, the verdict is that the cooperative has ceased to function effectively. This view loses sight of the fact that one of the most valuable accomplishments of a cooperative association is to be able to force competitors to pay as much as or more than could be received by selling through the association. When this is accomplished, not only do the patrons of the cooperative associations benefit by decreased marketing costs such as the associations afford, but all of those who sell to independent dealers profit also by their enforced reduction of margin.

It must not be forgotten that there are two ways in which total marketing cost may be reduced. In the first place the cooperative association may reduce it by operating on a non-profit basis, with actual cost at a minimum. In this case only those farmers who patronize the cooperative association receive the benefit. In the second place the cooperative association may offer such competition that the independent dealer is forced to pay as much as or more for the livestock than could be obtained by a producer by selling through the cooperative. In this case the patrons of the cooperative would retain their benefit, and in addition all the livestock producers would benefit from the reduced margins.

If the independent dealer continues to meet the competition of 
the efficient cooperative he must either sell at a higher price, or take a minimum profit, or reduce marketing expenses, or do all of these. No matter which course he follows, the producer will receive a price equal to the cooperative price. Herein lies the importance of the cooperative association in continually raising the plane of competition. The producer who refuses to patronize the cooperative because he can secure as high or a little higher price by selling to an independent dealer should not lose sight of the fact that that price may be the result of the work of the cooperative. The battle continues to rage in West Virginia between the independent dealers and the cooperative associations, and independent dealers continue to use the effective weapon of paying some men more than their livestock is worth.

A comparison of the average prices received by patrons who marketed their livestock through cooperative associations, with average prices paid by the independent dealers, in 1928 and 1929, reveals the fact that in most counties the dealers paid higher average prices than those received through the associations. If we assume that the cost of marketing, as shown earlier, was not excessive, and that the quality of animals was much the same, this fact indicates that the cooperatives, for two years at least, have forced the independent dealers to meet their competition in prices and, possibly, to decrease their margin of profit.

\section{METHODS EMPLOYED IN OBTAINING AND COMPARING PRICES}

The value of animals sold through the cooperative associations is recorded on "prorating sheets" and on duplicate checks sent to the patron. The prorating sheets show the name of the patron, the number and kind of animals, home weight, market weight, and an itemized statement of all marketing expenses.

It was possible from these records to calculate the "home price" for animals marketed through the shipping association. Incomplete records made it necessary to omit from the calculations prices of some animals marketed by a few associations and prices of all the animals of two or three associations, but approximately 85 percent of all animals marketed by cooperatives during 1928 and 1929 were included in the calculations. The years chosen were favorable because 1928 was a period of rising livestock prices and 1929 a period of falling prices in the state.

Managers of the cooperatives have not been very diligent in observing the provisions of the by-laws, which authorize them to record the home weight of all animals, but the home weights for a goodly number of animals have been recorded by each association. From these it was possible to calculate an average shrink which could be used with reasonable accuracy in converting market weights to home weights for those animals whose home weights were not recorded. The shrinks thus arrived at are shown in Table 28.

A record of prices which independent dealers paid for livestock 
was arrived at by the following method: Through a personal interview a schedule was filled out for 510 farmers in 11 counties. The following facts relative to livestock sold during 1928 and 1929 were obtained: (1) number of animals sold, by kinds; (2) horne weight of anima's sold; (3) either price per civt. or total value of each animal, whichever the farmer could remember.

Several independent dealers permitted the writer to transcribe from their records data concerning the weight and prices paid for animals which they had bought. Since these were the private records of the dealers, the accuracy of the prices and weights recorded is hardly open to question.

It was not possible to procure access to dealers' records in each county, but a comparison of average weights and prices obtained by means of the schedule with the average weights and prices procured from dealers' records in the same counties, indicates that the data obtained by the schedule are reasonably accurate. This comparison is shown in Table 29.

The close similarity of the results obtained by each method indicates that the records obtained by the schedule method in counties where dealers' records were not procured may also be considered reasonably accurate.

TABLE 29-Comparison of records of weights and prices of livestnck, as obtained from "seale records" of dealers and from a survey of farmers" sales, 1928 and 1929

\begin{tabular}{|c|c|c|c|}
\hline $\begin{array}{l}\text { Source of } \\
\text { reeords }\end{array}$ & $\begin{array}{c}\text { Number of } \\
\text { animals }\end{array}$ & $\begin{array}{l}\text { Average weight } \\
\text { (pounds) }\end{array}$ & $\begin{array}{l}\text { Average price } \\
\text { (per cwt.) }\end{array}$ \\
\hline \multicolumn{4}{|l|}{ STEERS } \\
\hline $\begin{array}{l}\text { Farmers } \\
\text { Dealers }\end{array}$ & $\begin{array}{l}9354 \\
5174 \\
\end{array}$ & $\begin{array}{l}1109 \\
1105 \\
\end{array}$ & $\begin{array}{r}\$ 10.76 \\
10.89 \\
\end{array}$ \\
\hline \multicolumn{4}{|l|}{ CALVES } \\
\hline $\begin{array}{l}\text { Farmers } \\
\text { Dealers }\end{array}$ & $\begin{array}{r}504 \\
97 \\
\end{array}$ & $\begin{array}{l}264 \\
197 \\
\end{array}$ & $\begin{array}{r}10.71 \\
7.52 \\
\end{array}$ \\
\hline \multicolumn{4}{|l|}{ COWS } \\
\hline $\begin{array}{l}\text { Farmers } \\
\text { Dealers }\end{array}$ & $\begin{array}{l}384 \\
255 \\
\end{array}$ & $\begin{array}{r}991 \\
1005 \\
\end{array}$ & $\begin{array}{l}7.45 \\
7.81 \\
\end{array}$ \\
\hline \multicolumn{4}{|l|}{ HEIFERS } \\
\hline $\begin{array}{l}\text { Farmers } \\
\text { nealers }\end{array}$ & $\begin{array}{l}1862 \\
2060 \\
\end{array}$ & $\begin{array}{l}840 \\
855\end{array}$ & $\begin{array}{r}9.25 \\
10.06 \\
\end{array}$ \\
\hline \multicolumn{4}{|l|}{ LAMBS } \\
\hline $\begin{array}{l}\text { Farmers } \\
\text { Dealers }\end{array}$ & $\begin{array}{l}16,397 \\
96,245\end{array}$ & $\begin{array}{l}76.8 \\
75.2\end{array}$ & $\begin{array}{l}11.12 \\
11.22\end{array}$ \\
\hline
\end{tabular}

The largest difference between data obtained from the two sources, as shown in Table 29 , is in the price of calves. This difference in reported price is due largely to the fact that farmers sold many of their calves as veals, either to local markets or hucksters, while the price procured from dealers' records was largely for calves too old for veal. From the two sources the records of the average weights and prices are very similar in the case of steers, heifers, cows, and lambs.

Records from farmers or independent dealers or from both were obtained in 12 counties. This number includes some counties in 
which the strongest cooperative shipping associations were operating, some in which the associations were weak, and some where the association was not operating at all.

A comparison of the average home price which patrons of the cooperative association received for lambs weighing 60 pounds and above with the average price paid by independent dealers for lambs of the same weight is shown for 1928 in Table 30 and for 1929 in Table 31 .

\section{LAMB PRICES}

In Table 30 the average weights and prices of 6,892 lambs (60 pounds and above) marketed through the various cooperative associations are compared with those of 50,831 lambs sold to independent dealers in 1928. The average weight of this group of lambs marketed by the cooperative association was 73.8 pounds (home weight), while for those sold to independent dealers it was 76.3 pounds. The farmers who sold these lambs through the cooperatives received an average farm price of $\$ 11.08$ per cwt., while those se!ling to independent dealers received an average of $\$ 11.31$ per cwt. During 1928 farmers who sold to independent dealers received on an average 23 cents per cwt. more than those who sold through the cooperatives, in spite of the fact that many reliable parties claim that the cooperatives marketed a larger percentage of higher quality lambs than did the independent dealer.

In Greenbrier county alone did the cooperative average price exceed that of the independent dealer. In Roane county, where the cooperative association was one of the most active in the state, the average price received from each agency was practically the same. It may be observed from Table 30 that there was little difference between the average price received in counties where cooperatives were operating and in those where they were not operating.

In Table 31 the average home weights and home prices of 7,823 lambs (60 pounds or over) marketed through cooperatives are compared with those of 58,291 lambs (60 pounds or over) sold to independent dealers in 1929. In that year, as in 1928. both the average price and weight of the lambs marketed through the cooperatives were below those of the lambs sold to independent dealers. The average weight was only slightly below, but the average price was $\$ 1.17$ per cwt. below the average price paid by the independent dealers. The average price for lambs in counties where conperatives were not operating again compares favorably with the average price in counties which had active associations.

In 1929, as in 1928, the average price of the cooperative was higher than the price paid by dealers only in Greenbrier county. Two reasons may account for this. The Greenbrier association not only had lower costs than the associations in other counties but it is claimed by some people familiar with the situation that this association marketed a much larger percentage of top lambs than did the 

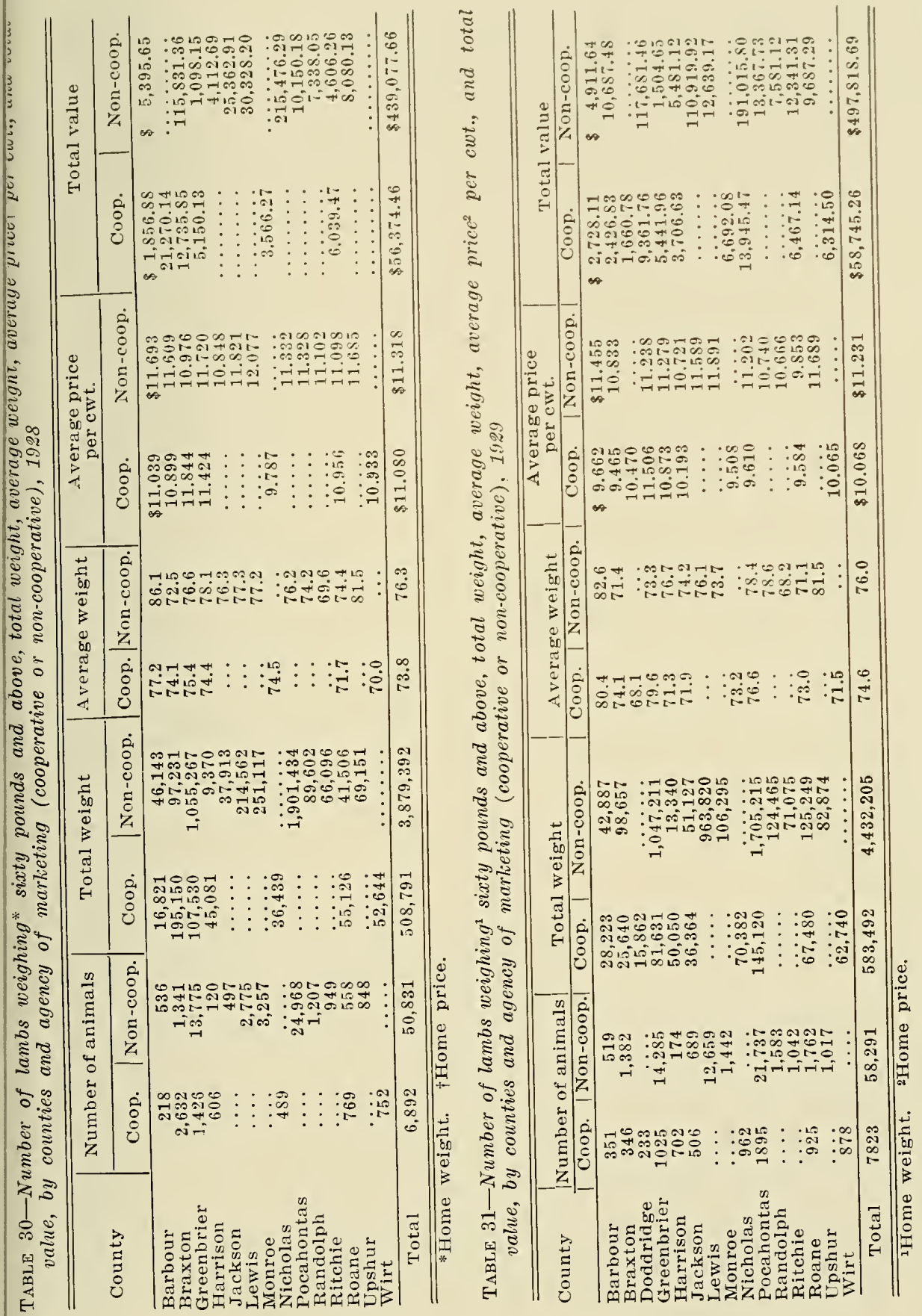
other associations, in comparison with the percentage of top lambs marketed by the independent dealers in the corresponding counties.

During these years the manager of the Greenbrier association was not very active, shipping mostly only the animals of some of the better producers in the county. This lack of aggressive competition on the part of the manager may be an additional reason for the difference in prices. Patrons of the Greenbrier cooperative however received an average of 49 cents per cwt. less than dealers paid in Monroe, a neighboring county, where the cooperative was not active, but where the lambs are of a somewhat higher quality and where there was unusual competition between independent dealers.

Tables 32 and 33 show a comparison of the average home prices for lambs weighing less than 60 pounds, home weight, marketed through cooperatives, with the average home prices for the same weight-class of lambs paid by independent dealers in 1928 and 1929, respectively.

For 1928 the comparison is between 1,435 lambs weighing less than 60 pounds marketed through cooperatives, and 1,223 lambs sold to private dealers. The average weight of these two groups was the same, but the average home price paid by independent dealers was 62 cents per cwt. above the price received through the cooperative. In Roane county alone was the cooperative price higher than the independent dealer price, but the numbers involved are two small for a dependable comparison.

In 1929 the average home price of 1,290 lambs weighing less than 60 pounds, sold through the associations, was 61 cents per cut. below the average home price of 2,297 lambs of the same weightclass sold to independent dealers. These data lend weight to the contention that independent dealers do not give great consideration to quality when buying lambs.

\section{CATTLE PRICES}

\section{Steers}

Table 34 shows a comparison of the average weight and price of 771 steers marketed through the cooperative associations during 1928 with those of 7,058 steers sold to independent dealers.

The average weight of the steers marketed through the associations was 1,117 pounds, while of those sold to independent dealers it was 1,091 . The average home price received for the steers marketed through cooperatives was $\$ 11.17$ per cwt., or $\$ 0.50$ per cwt. more than the $\$ 10.67$ for those sold to independent dealers. Not all of the latter group went to market, but all those sold through the shipping associations went to a terminal market, except a few which were sold to Ohio cooperative shipping associations to be distributed to their patrons for feeder-stock.

It may be observed from the table that in only one county, Greenbrier, was the shipping association price higher than the price paid by independent dealers; the average weight was also greater. 


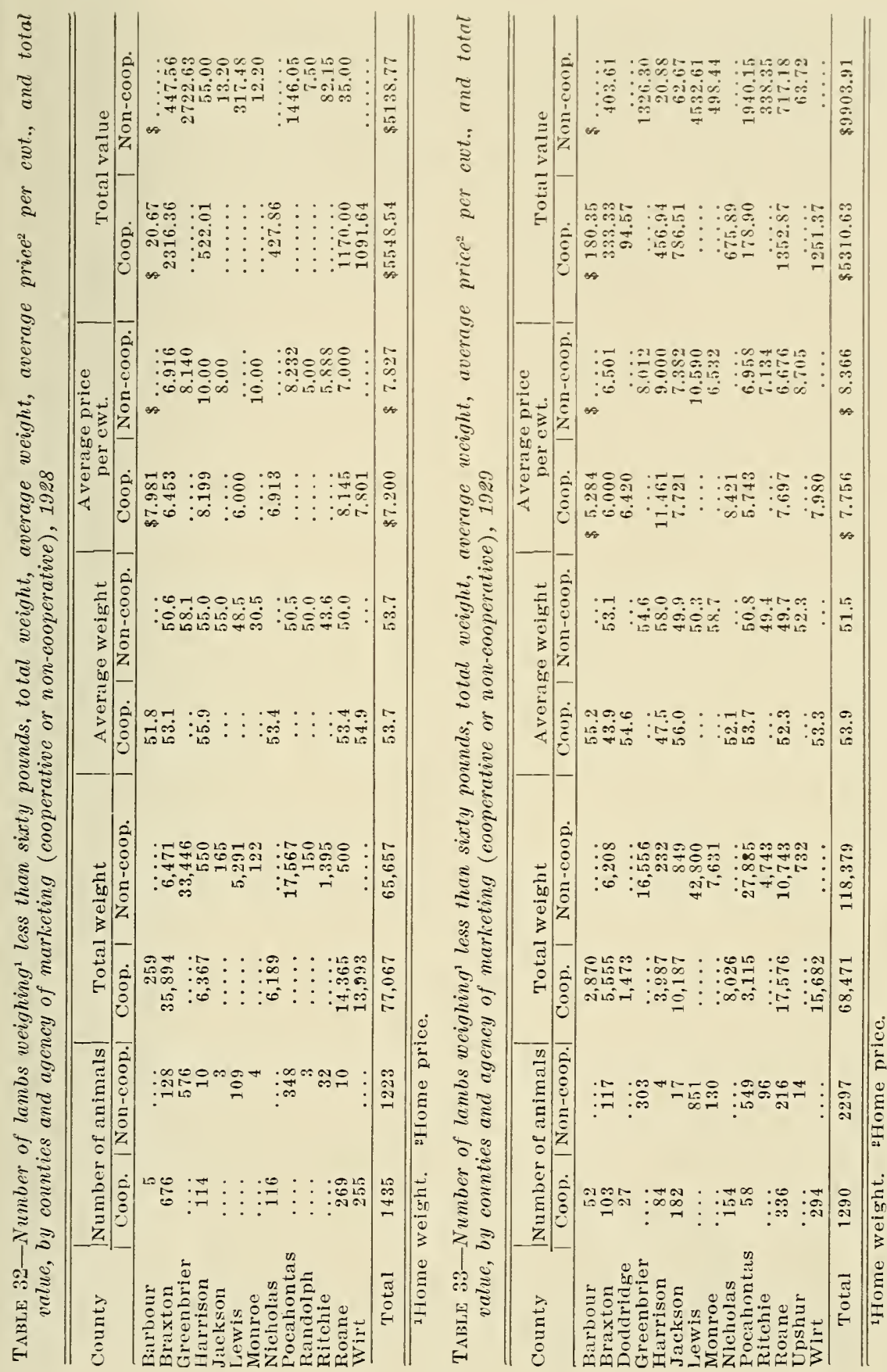


The Greenbrier association handled some of the best cattle in the county and a smaller proportion of light cattle and cattle of low grade than any other of the associations. The associations in Roane and Harrison counties handled lighter cattle and a larger proportion of feeder cattle than were handled by independent dealers.

A comparison of the average weight and home price of 714 steers marketed by the cooperative associations in 1929 is made in Table 35 with those of 7,470 steers sold to independent dealers.

The average weight of the steers marketed through the association in 1929 was 1,047 pounds and that of steers sold to independent dealers was 1,123 pounds, just the reverse of the situation in 1928 . The average price received from sales through the association was $\$ 9.53$, while the steers sold to the independent dealers brought an average price of $\$ 10.93$ per cwt. In no county was either the average weight or price as great for the steers sold through the associations as for those sold to independent dealers.

A more significant comparison of prices may be obtained by comparing the prices of animals in the same weight groups. Weight is one of the factors in price determination, but is not the only one and probably not the most important one. However, it was the only tangible factor available on which a comparison could be made. From replies to a questionnaire sent to commission merchants and county agricultural agents it appears as though the cattle handled by dealers in West Virginia, on an average, have been somewhat higher in quality than those handled by cooperative shipping associations. This is just the reverse of the situation respecting the quality of lambs. With quality a somewhat uncertain factor, this price comparison lacks exactitude, but may give some indication of the situation, if the prices for animals in the same weight groups are used.

Tables 36 and 37 show a comparison, by counties, of the average home weights and prices of steers weighing from 550 to 899 pounds marketed through cooperatives in 1928 and 1929, respectively, with those of steers of the same weight groups sold to independent dealers.

The comparison for 1928 is for 126 steers (550 to 899 pounds) marketed through cooperatives with 1,122 steers of the same weight class sold to independent dealers. The steers marketed through the cooperatives averaged 47 pounds heavier than those sold to private dealers, but the price per cwt. was 79 cents less. In only one county, Harrison, was the cooperative price higher than the independent dealer price. The numbers compared for this county are too small, however, to be of much significance.

The comparison for 1929 was between 168 steers (550 to 899 pounds) marketed cooperatively and 1,040 sold to private dealers. The average weight was practically identical for both groups, but the price paid by independent dealers was $\$ 1.26$ per cwt. more than the price received through cooperatives. 

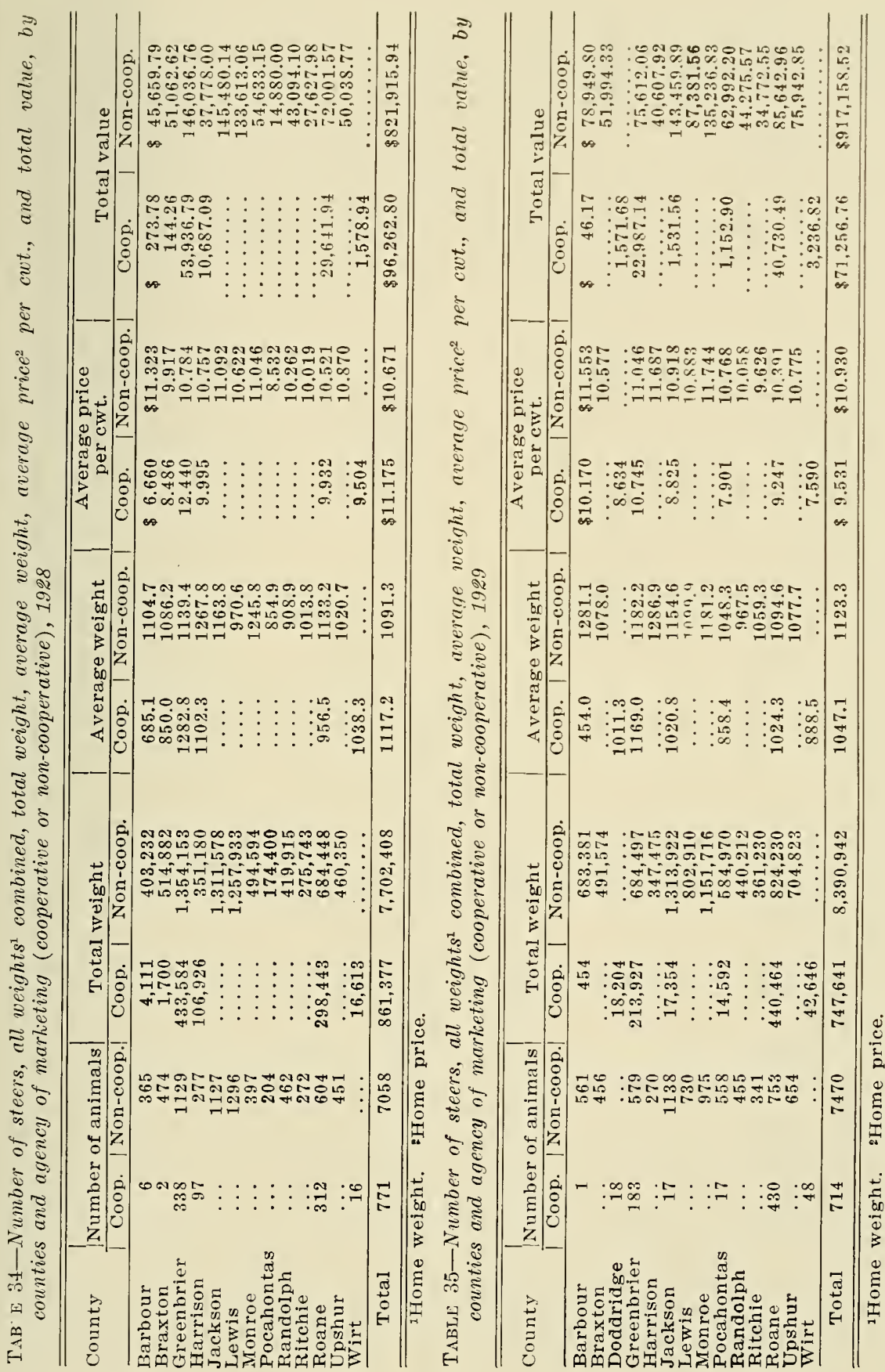


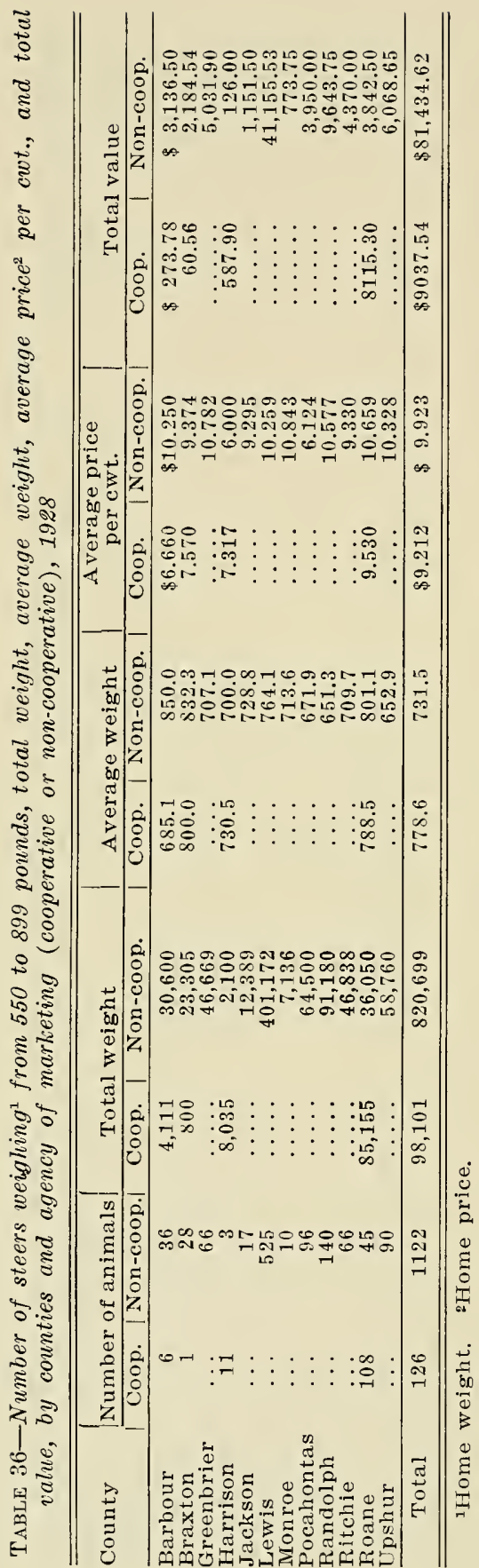

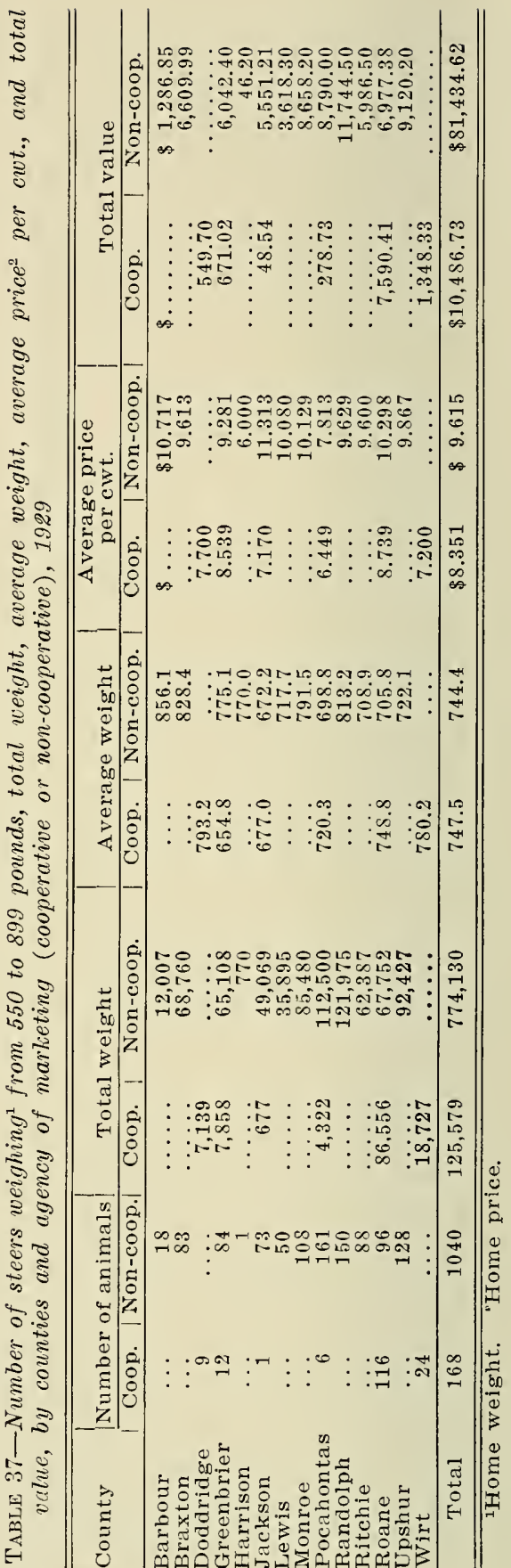


The independent dealers do not ship a iarge number of steers in this weight class, but rather distribute them to other farmers in the state for further grazing. If the trend of cattle prices appears to be upward, the independent dealer can afford to pay a higher price for steers of this class to handle in this way than if they were put in the market for slaughter.

Tables 38 and 39 show a comparison, by counties, of the average home weight and price of steers weighing from 900 to 1099 pounds which were marketed through the cooperatives in 1928 and 1929, respectively, with those of steers sold to independent dealers during the same years.

For 1928 the comparison was between 195 steers (900 to 1099 pounds) marketed through the cooperatives and 1,525 sold to independent dealers. The average weight of the two groups was practically the same. The average price received from sales to independent dealers was 20 cents per cwt. more than the price received from sales through cooperatives. In only one county, Roane, was the cooperative price higher than the independent dealer price. The numbers for Greenbrier county are too small for comparison. Fortysix percent of the steers sold through the Roane association in 1928 fell in this weight group. The average price for the cooperative in Roane county was $\$ 1.64$ above the price paid by dealers for this weight-class of steers. But the dealer price was higher in most of the other counties.

During 1928 the Roane association selected and sold most of its good stock cattle to an Ohio cooperative. The cattle were selected with care and hence a premium price was received. This circumstance, in part, may explain why the cooperative price was considerably above the independent dealer price during this year.

For 1929 the comparison was between 212 steers (900 to 1099 pounds) marketed through the cooperatives and 1,265 sold to independent dealers. The average weight of the steers sold through cooperatives was somewhat greater, but the average price was 98 cents per cwt. lower than the price paid by independent dealers. In no county was the average price received through cooperative sales as much as that received from sales to independent buyers.

Tables 40 and 41 show a comparison, by counties, of the average weight and price of steers weighing from 1,100 to 1,299 pounds which were marketed through the cooperatives in 1928 and 1929, respective$1 y$, with those of steers sold to independent dealers.

For 1928 the comparison was between 286 steers (1100 to 1299 pounds) sold through the cooperatives and 3,264 sold to independent dealers. The average weight of the steers sold through the cooperatives was somewhat greater than of those sold to independent dealers and the average price was 67 cents per cwt. more. The average price for cooperative sales was increased by the exceptionally favorable showing which the Greenbrier county association made. In only one other county, however, was the cooperative price higher than the dealer price. 

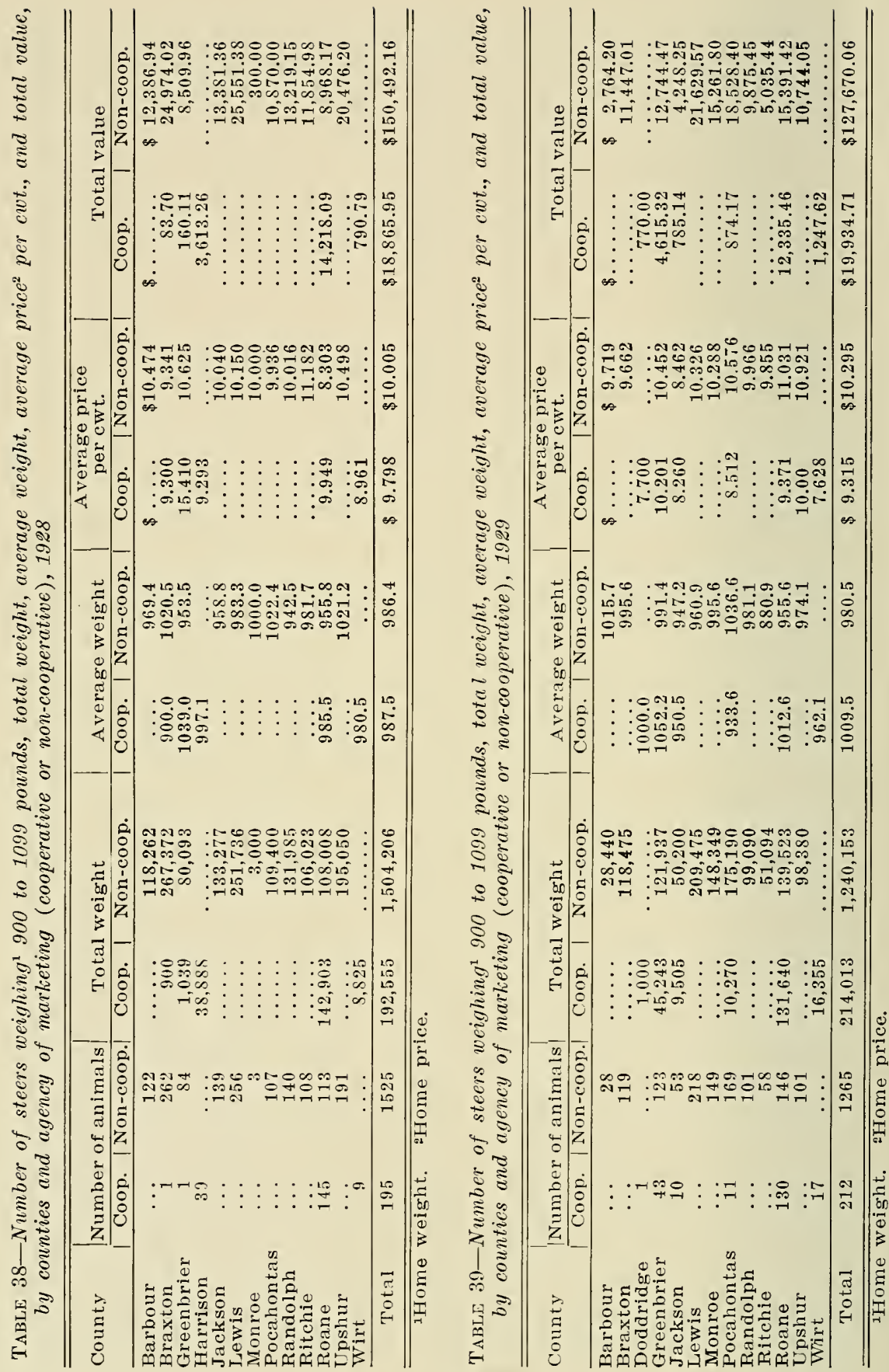


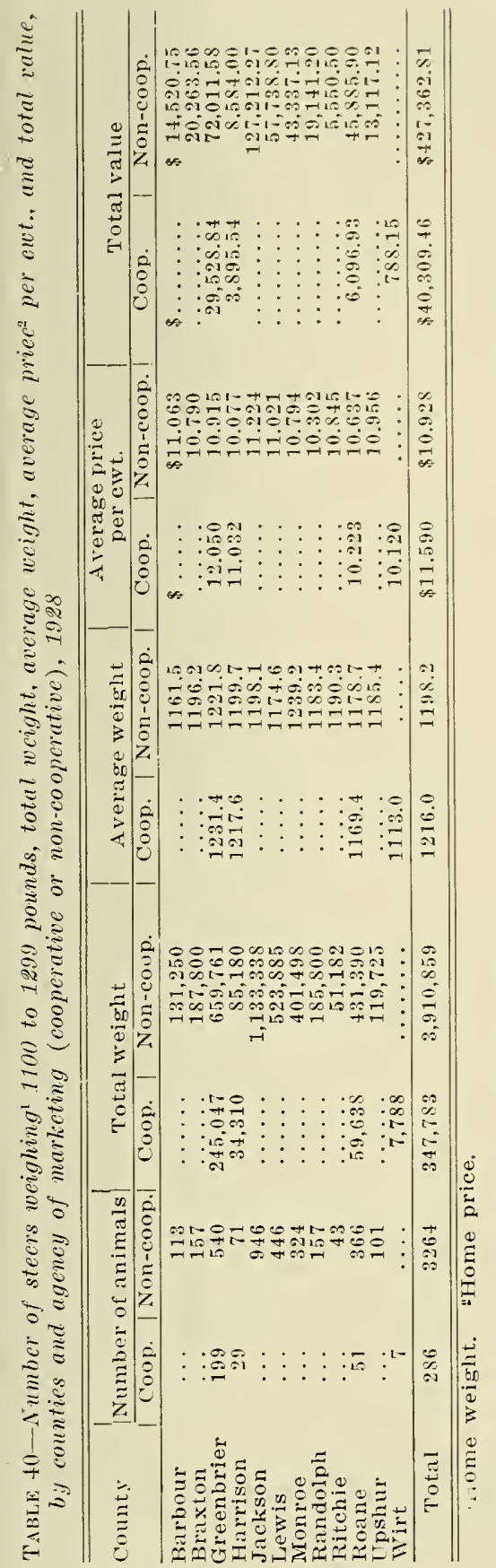

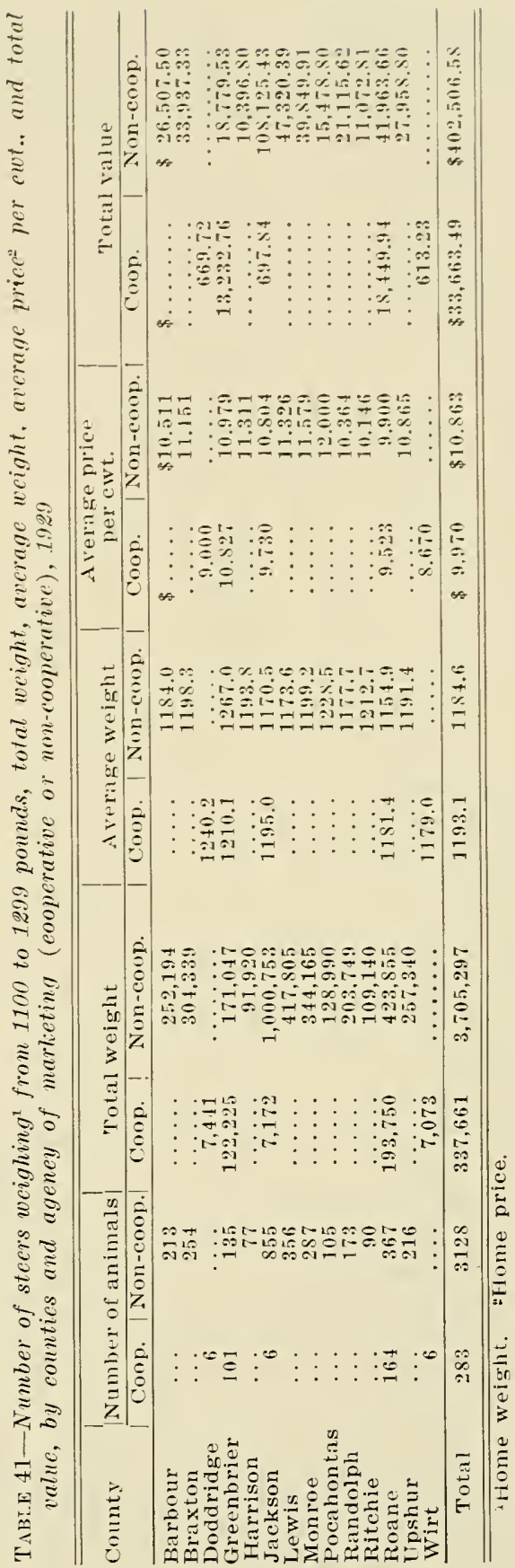


For 1929 the comparison was between 283 steers (1100 to 1299 pounds) sold through the cooperatives and 3,128 steers sold to independent dealers. The average weight of the steers sold through the cooperative was again somewhat greater, but the average price was 89 cents per cwt. lower than of those steers sold to independent dealers.

Tables 42 and 43 show the average weight and price of steers weighing from 1300 to 1499 pounds marketed by the cooperatives in 1928 and 1929, respectively, compared with those of steers of the same weight-class sold to independent dealers. In Greenbrier county alone are the numbers large enough to make any adequate comparison. In 1928 patrons of the cooperative in this county received a higher average price for steers in this weight group than the price paid by independent dealers, but in 1929 independent dealers paid the higher average price.

Tables showing the average weight and prices of steers weighing 1500 pounds and over and of steers weighing from 250 to 549 pounds were prepared. Because of the small number of such animals marketed by the cooperatives, no valid comparison of prices could be made. The animals of these weight groups however were included in the summary Tables 34 and 35 .

\section{Heifers}

Tables 44 and 45 show the average home weight and price received for heifers sold through the cooperative associations compared with those of heifers sold to independent dealers during 1928 and 1929 , respectively.

In 1928 the average home price received for heifers marketed through the cooperative was 15 cents per cwt. above the price paid by independent dealers. The Roane county association handled a large majority of the heifers sold by cooperatives during this year. The price received by patrons of this association was 19 cents per cwt. above the independent dealer price in that county. In 1929, however, the independent dealers' average price was $\$ 1.59$ per cwt. above the association price. In the Roane association the price was also well below the independent dealer price in that year.

Tables 46 to 51 show a comparison of average prices of the heifers when divided into various weight classes. It may be observed that the price paid by independent dealers was consistently above the price received through the cooperatives in each weight class during both years, except that of the 850 to 1,049 pound class in 1928. It was in this year that the Roane county association sold stock cattle to the Ohio cooperative.

\section{Calves}

Tables 52 and 53 show the average home price of calves weighing less than 250 pounds, received through the cooperatives, compared with that of calves sold to independent dealers in 1928 and 1929, respectively. 

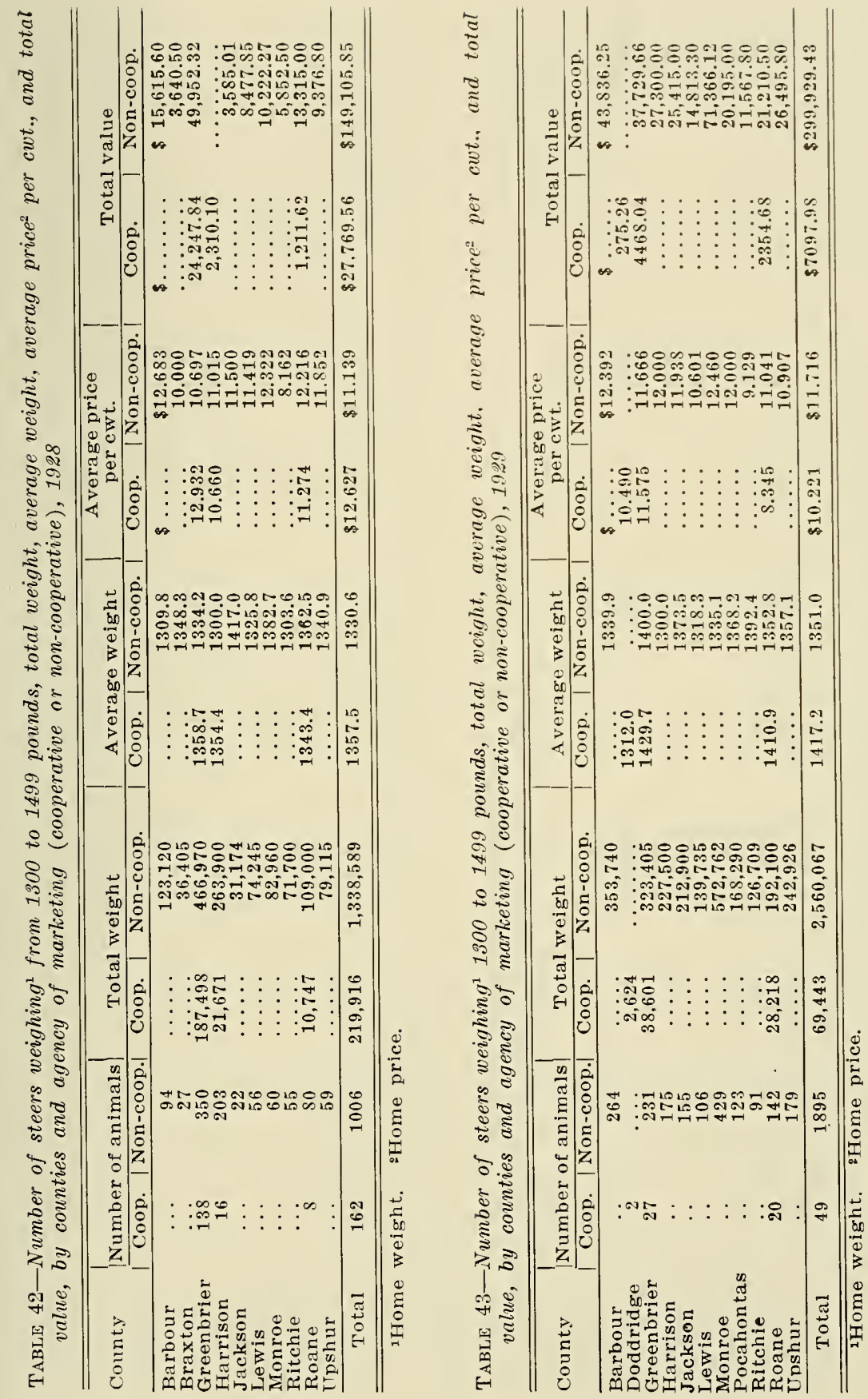


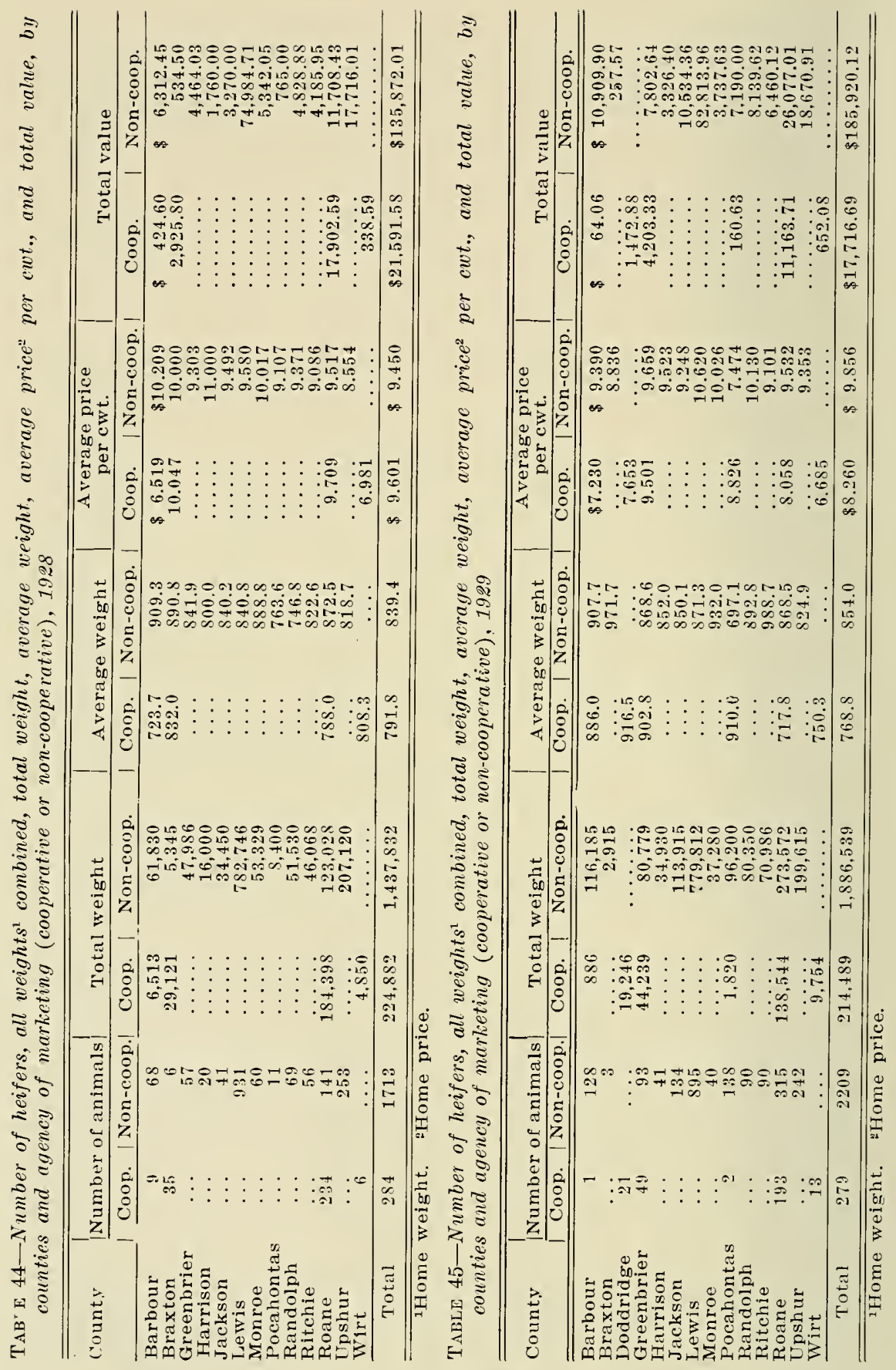




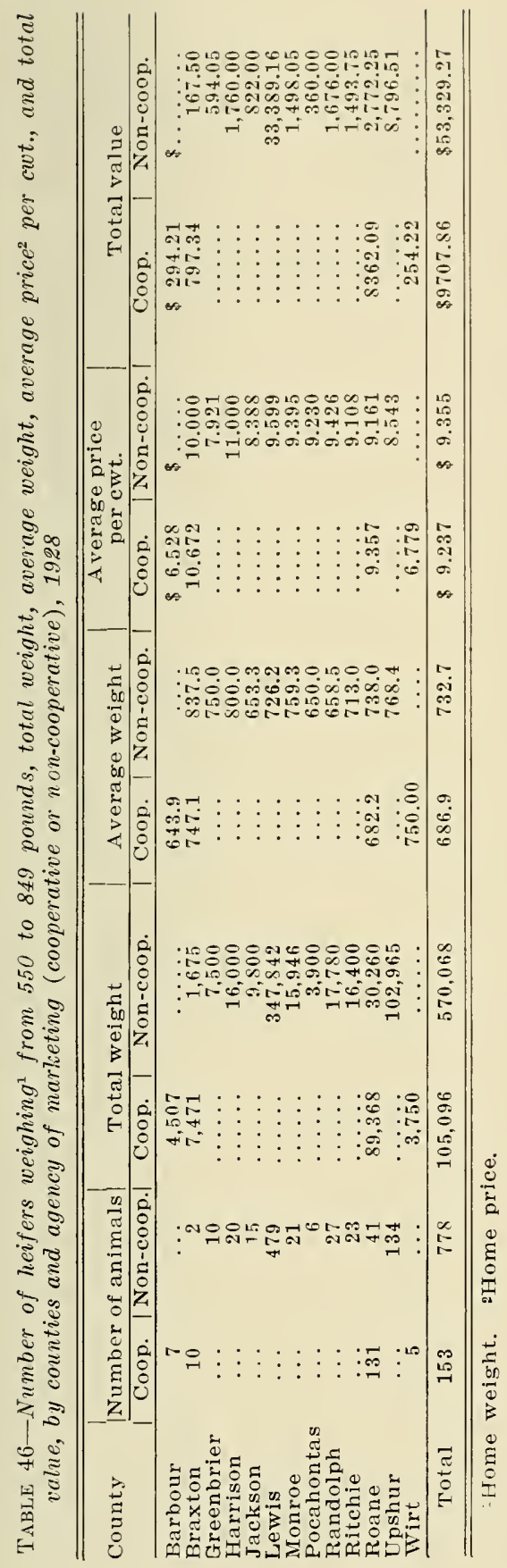

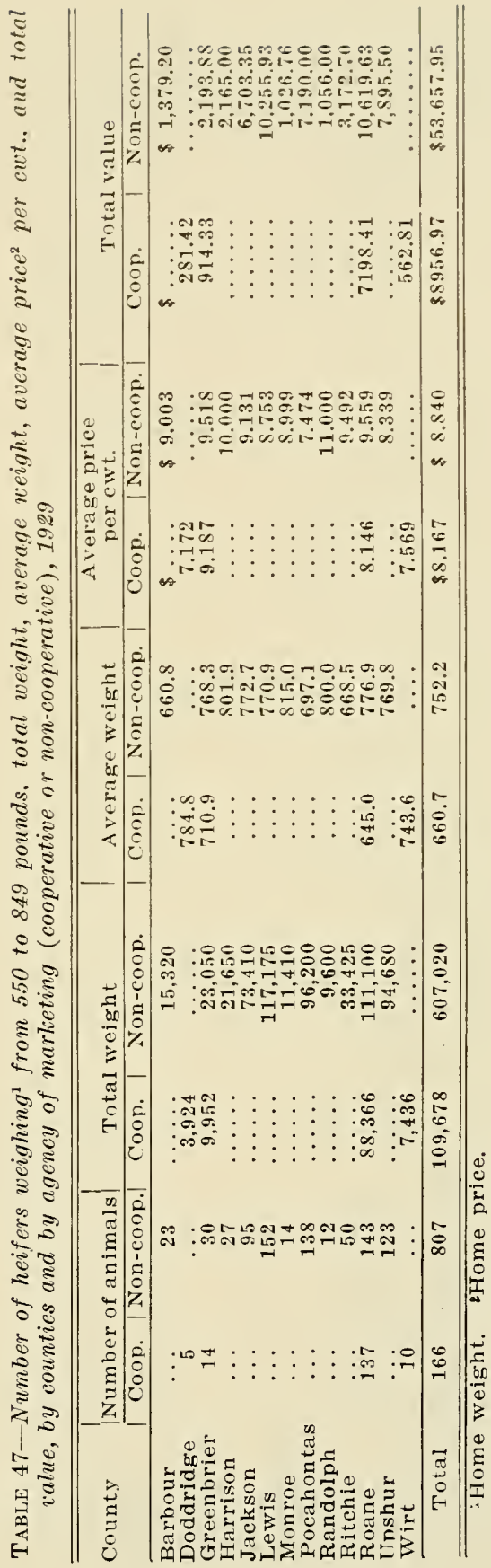



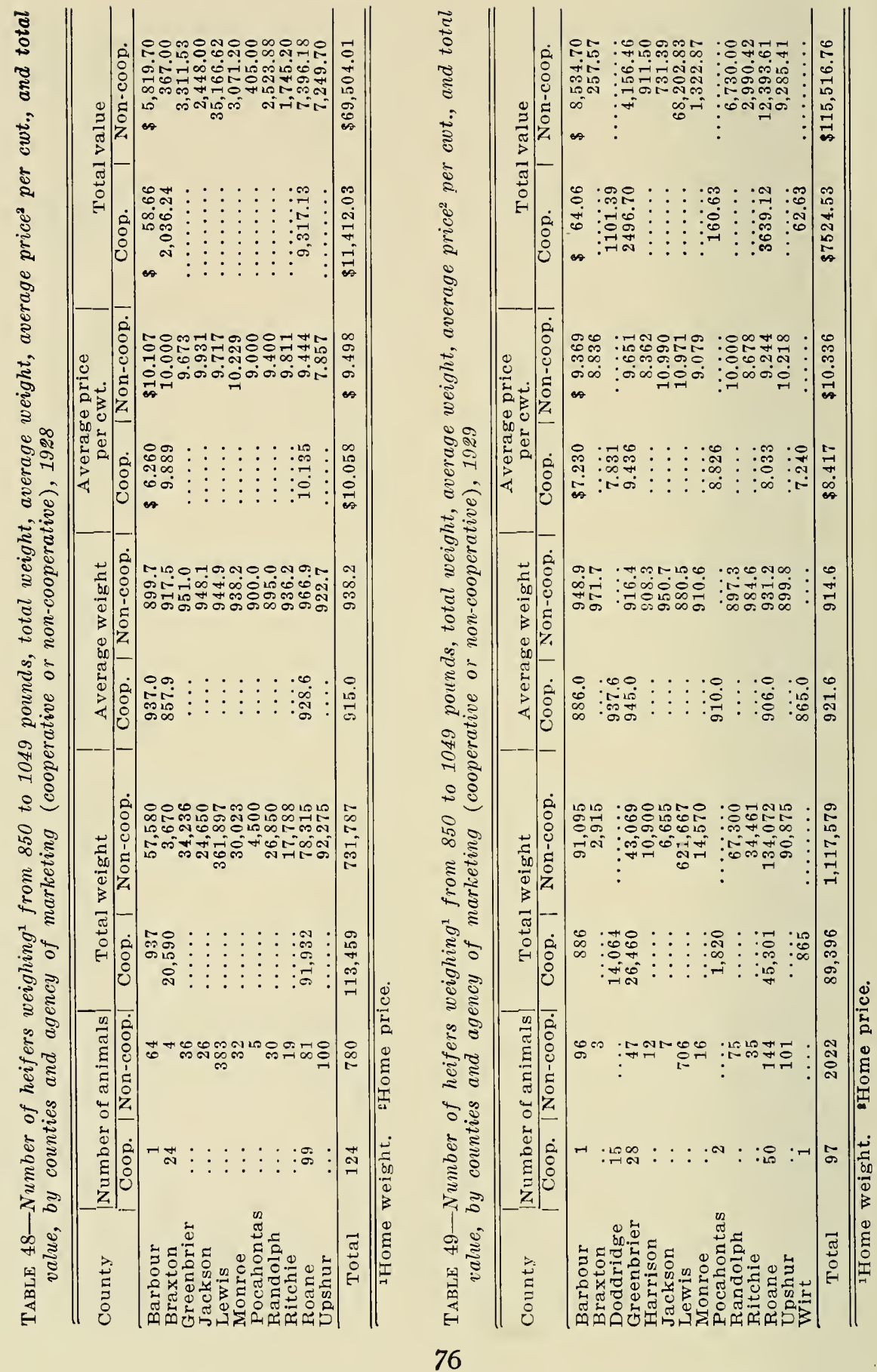

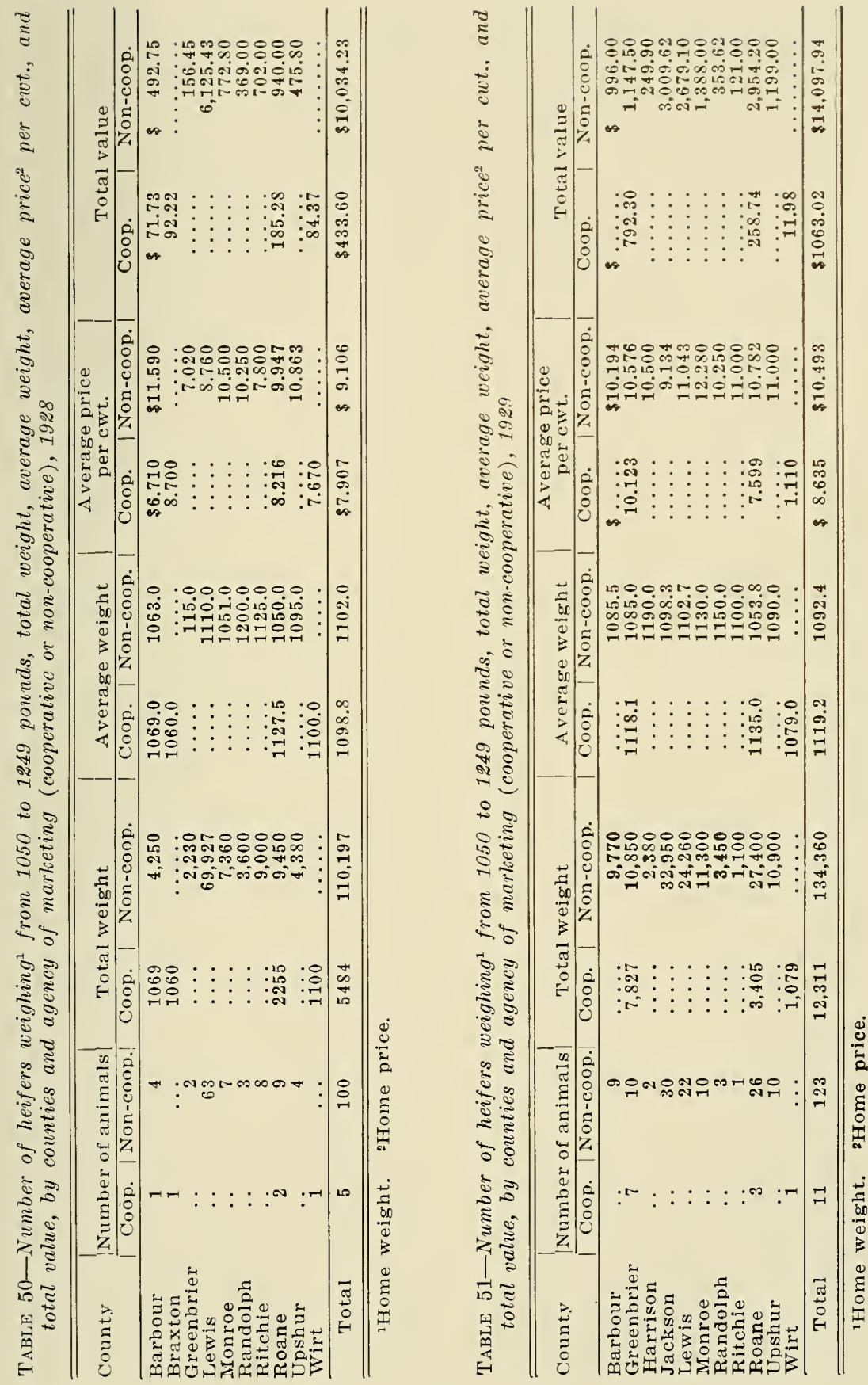

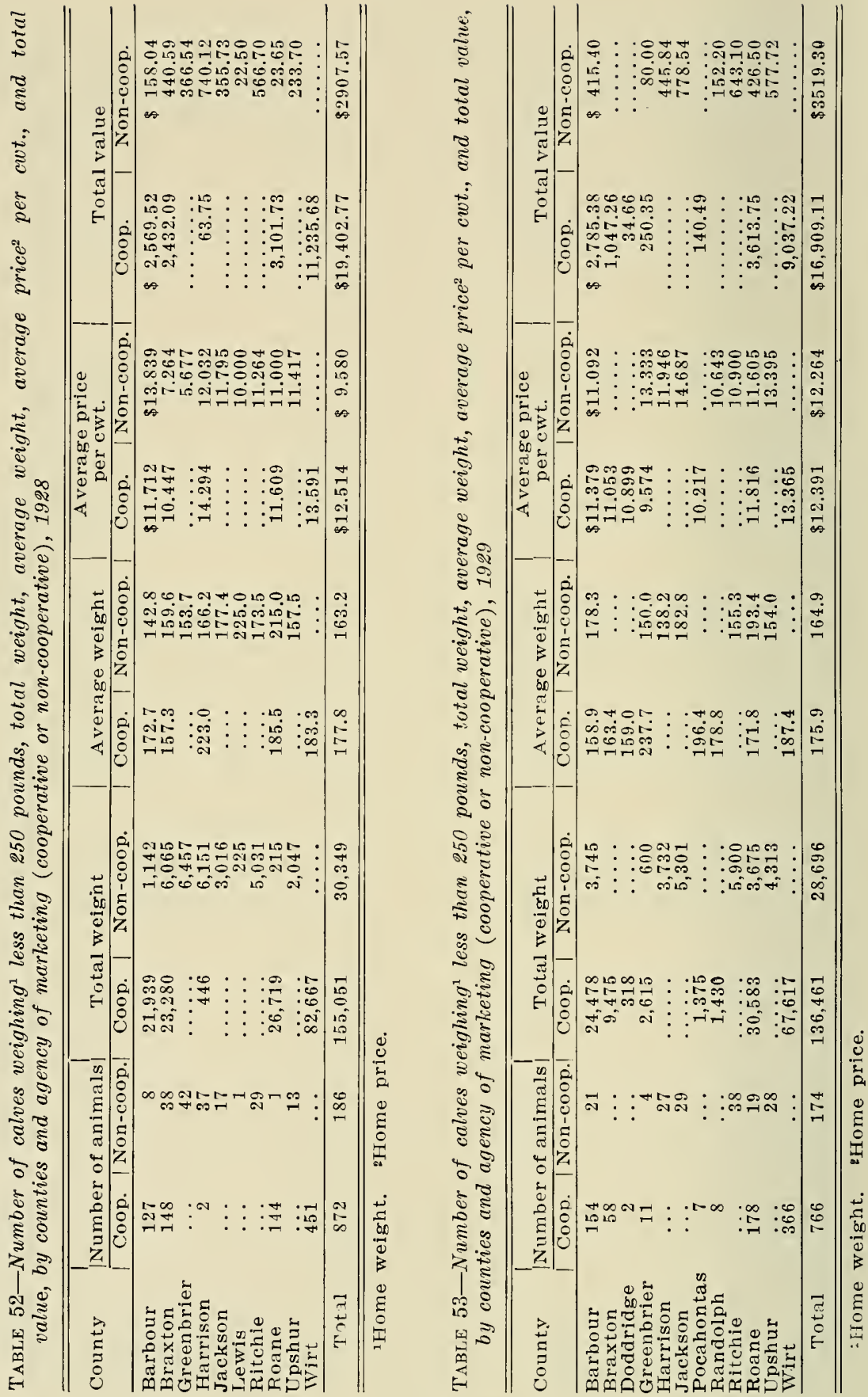
During 1928 the association price was $\$ 2.93$ per cwt., but during 1929 only 13 cents per cwt. above the independent dealer price. It should be recalled in this connection that several of the cooperatives made an especial effort to put veal calves on the market at their proper stage of deve'opment, while independent dealers as a general rule did not put forth such effort.

Tables 54 and 55 show the average home price of calves weighing in excess of 250 pounds, sold through the cooperatives, compared with that of calves sold to independent dealers during 1928 and 1929, respectively. The average price of the cooperatives was higher in 1928 but lower in 1929 than the independent dealer price, indicating the same tendency as shown in previous tables dealing with mature animals.

\section{Cows}

Tables 56 and 57 show the average home price of cows sold through the cooperatives compared with that of cows sold to independent dealers during 1928 and 1929, respectively.

In both years the average price paid for cows by independent dealers was considerably above the price received from sales throngh the cooperatives, the difference being somewhat greater in 1929 than in 1928. It is doubtful, however, if this is a fair comparison because of the difference known to exist in the kind of cows handled by each agency. All of the cows marketed through the associations went to the terminal market, while a percentage (it is not known what percentage) of the cows sold to independent dealers were retained on the farm as milk cows or breeding animals. From this it may be assumed that the cows sold to independent dealers were of better quality than those sent to market by the cooperatives and, therefore, it is to be expected that the price paid by the former would be greater than that received through the latter.

\section{CHANGES IN DEALER, COOPERATIVE, AND TERMINAL MARKET PRICE,} 1928 AND 1929

It may be observed from the preceding tables, showing the average prices for steers of the varions classes, that there was a considerable decrease in the prices of the steers marketed through the cooperatives in 1929 from the prices received in 1928. while in most weight classes there was a slight increase in the prices paid by independent dealers in 1929 above that paid in 1928.

Table 58 shows the monthly average price of steers on the Pittsburgh market, the average price for the year received by patrons of the cooperative livestock shipping associations, and the average price for the year paid by independent dealers in West Viroinia. From this table it may be observed that during the months when the large majority of West Virginia cattle were marketed, August, September, and October, the average prices of steers on the Pittsburgh market 

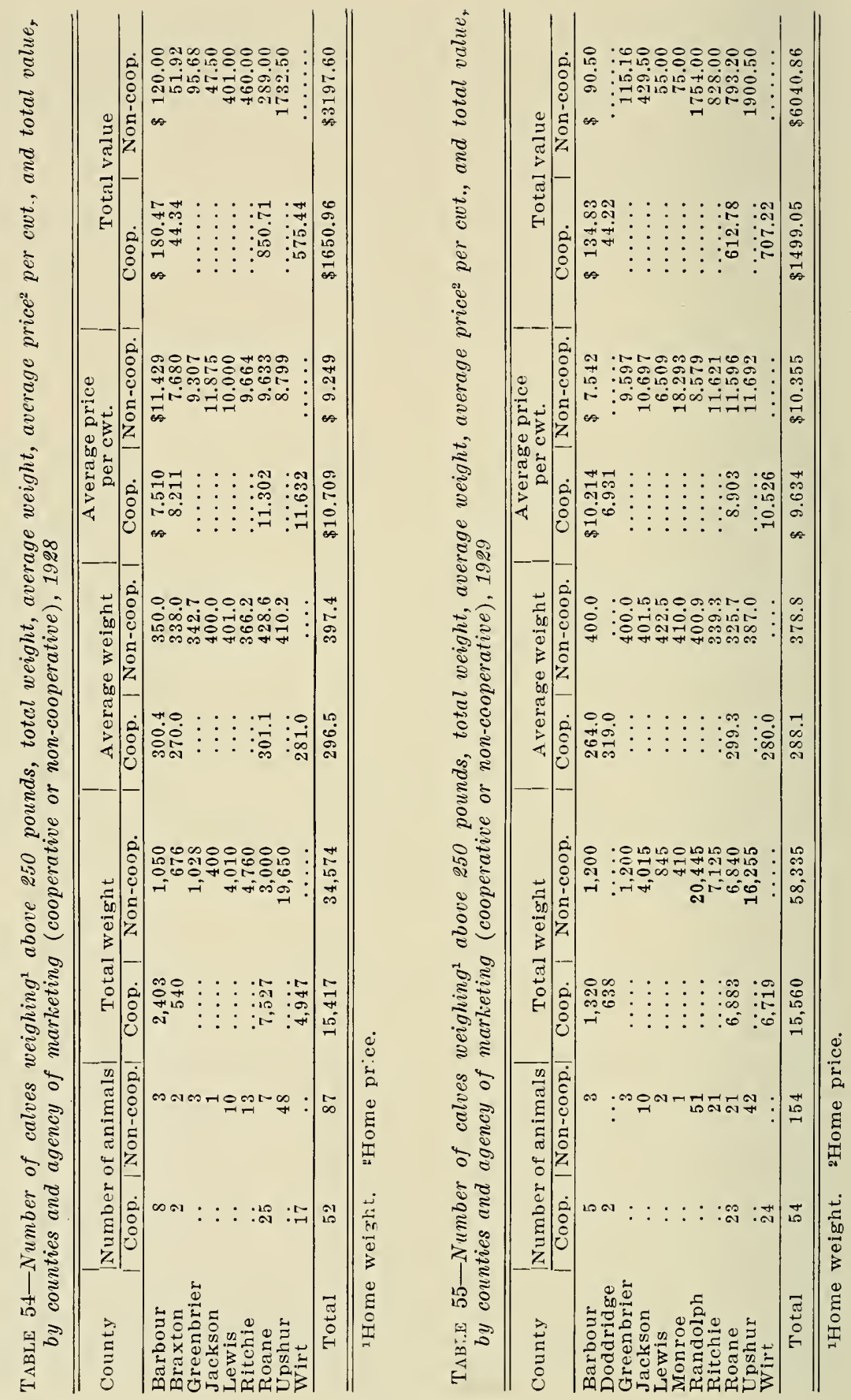


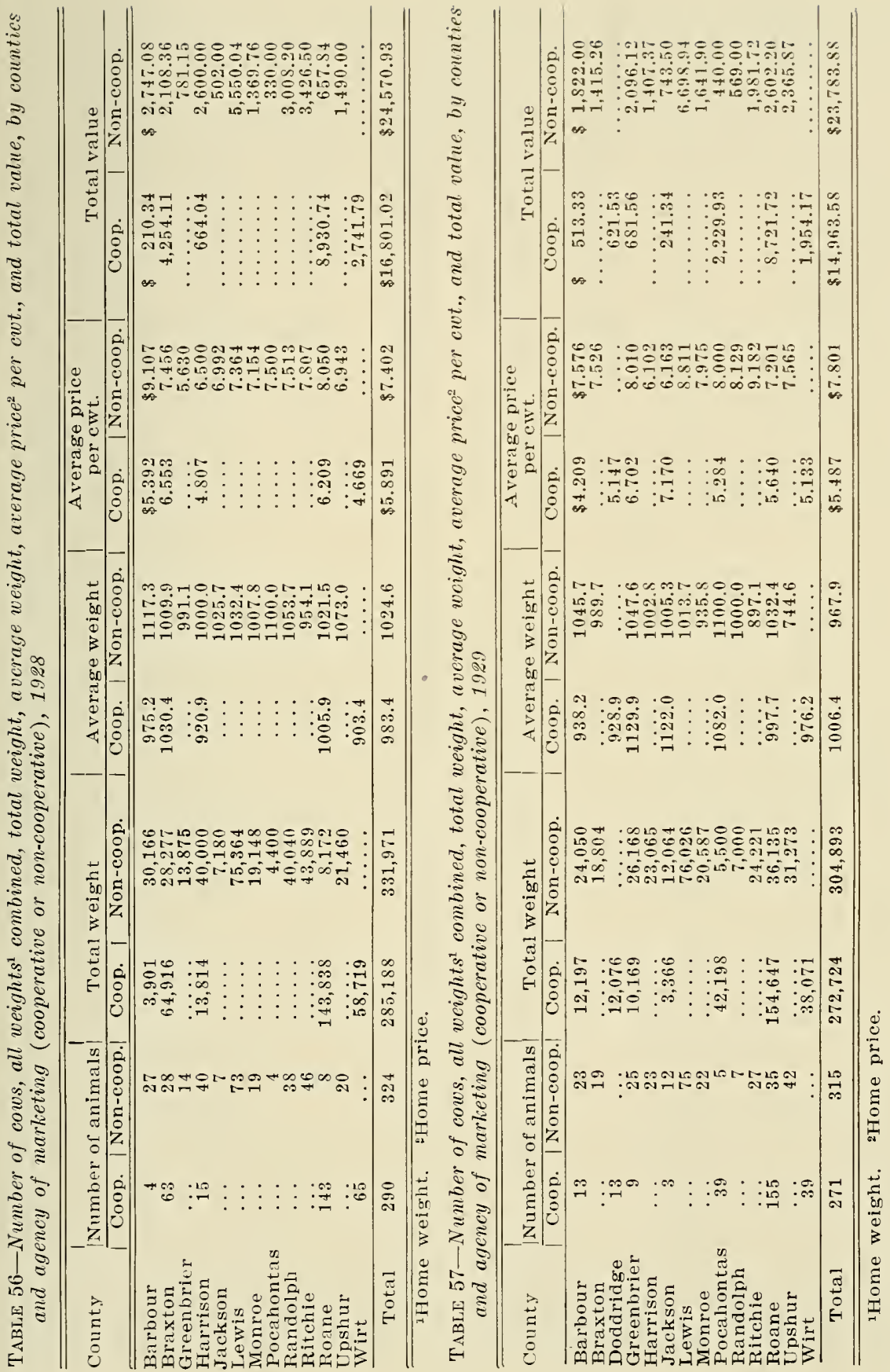


TABLE 58-Monthly average price per cwt. of steers on the Pittsburgh market, average price received by patrons of cooperative shipping associations, and average price paid by dealers in West Virginia, 1928 and 1929

\begin{tabular}{|c|c|c|c|c|c|c|c|c|}
\hline \multirow[t]{2}{*}{ Month } & \multicolumn{2}{|c|}{$\begin{array}{c}\text { GOOD } \\
\text { STEERS } \\
1100-1300 \text { pounds }\end{array}$} & \multicolumn{2}{|c|}{$\begin{array}{c}\text { GOOD } \\
\text { STEERS } \\
950-1100 \text { pounds }\end{array}$} & \multicolumn{2}{|c|}{$\begin{array}{c}\text { MEDIUM } \\
\text { STEERS } \\
850 \text { pounds up }\end{array}$} & \multicolumn{2}{|c|}{$\begin{array}{c}\text { COMMON } \\
\text { STEERS } \\
\$ 50 \text { pounds up }\end{array}$} \\
\hline & 1928 & 1929 & 1928 & 1929 & 1928 & 1929 & 1928 & 1929 \\
\hline $\begin{array}{l}\text { January } \\
\text { February } \\
\text { March } \\
\text { April } \\
\text { May } \\
\text { June } \\
\text { July } \\
\text { August } \\
\text { September } \\
\text { October } \\
\text { November } \\
\text { December }\end{array}$ & $\begin{array}{r}\$ 13.64 \\
13.61 \\
13.28 \\
13.37 \\
13.55 \\
14.19 \\
14.81 \\
14.97 \\
14.88 \\
13.58 \\
13.28 \\
13.53\end{array}$ & $\begin{array}{r}\$ 13.40 \\
12.31 \\
13.25 \\
13.68 \\
14.00 \\
14.27 \\
14.79 \\
13.85 \\
13.00 \\
12.50 \\
12.48 \\
12.78\end{array}$ & $\begin{array}{r}\$ 13.38 \\
13.38 \\
13.16 \\
13.29 \\
13.48 \\
14.19 \\
15.00 \\
15.13 \\
15.00 \\
13.70 \\
13.41 \\
13.65\end{array}$ & $\begin{array}{r}\$ 13.60 \\
12.44 \\
13.38 \\
13.84 \\
14.25 \\
14.46 \\
14.91 \\
13.87 \\
12.72 \\
12.50 \\
12.54 \\
13.00\end{array}$ & $\begin{array}{l}\$ 11.88 \\
12.52 \\
12.47 \\
12.76 \\
12.85 \\
13.31 \\
13.69 \\
13.52 \\
13.50 \\
12.70 \\
12.50 \\
12.56\end{array}$ & $\begin{array}{r}\$ 12.55 \\
11.47 \\
12.38 \\
12.88 \\
13.25 \\
13.50 \\
13.70 \\
12.80 \\
11.97 \\
11.60 \\
11.72 \\
12.06\end{array}$ & $\begin{array}{r}\$ 9.62 \\
10.55 \\
10.75 \\
11.12 \\
11.40 \\
11.91 \\
11.88 \\
11.30 \\
11.22 \\
10.80 \\
10.66 \\
10.68\end{array}$ & $\begin{array}{r}\$ 10.65 \\
9.62 \\
10.56 \\
11.12 \\
11.50 \\
11.62 \\
11.48 \\
10.50 \\
10.03 \\
9.85 \\
10.00 \\
10.16\end{array}$ \\
\hline $\begin{array}{l}\text { *Association } \\
\text { Ave. Price } \\
\text { *Dealer } \\
\text { Ave. Price }\end{array}$ & 11.59 & 9.97 & 9.80 & 10.29 & 9.21 & 8.35 & 9.21 & 8.35 \\
\hline
\end{tabular}

*The price given is the average price for steers falling within the weight group indicated.

Data from reports of Livestock, Meats, and Wool Division, Bureau of Agricultural Economies, United States Department of Agriculture.

were considerably lower in 1929 than in 1928. Data in the table show that this difference in prices was better reflected in the cooperative price than in the independent dealers' prices.

Chart 5 , constructed from data in Table 58 , shows the average monthly price of good steers, weighing 1100 to 1300 pounds, on the Pittsburgh market during 1928 and 1929, and the average home price of steers sold through cooperatives and to independent dealers during those years.

The majority of the cattle were marketed in August and Septem-

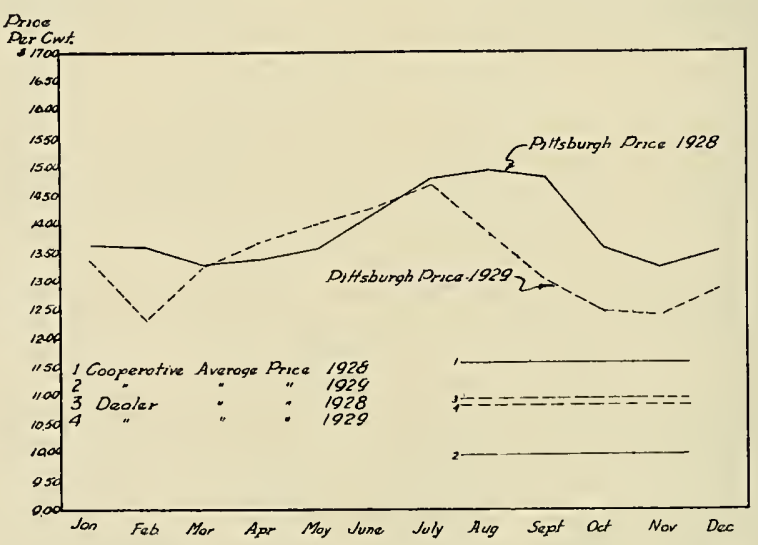

Chart 5-The monthly average price of good steers weighing 1100 to 1300 pounds on the Pittsburgh market, the average home price receired by the patrons of the cooperative associations, and the average price paid by dealers for steers of this weight class, 1928 and 1929 
ber. The August 1929 terminal market price of steers of this weight was \$1.12 per cwt. below the 1928 price. The September $192 y$ price was $\$ 1.88$ below the September 1928 price. The October 1929 price was $\$ 1.08$ below the October 1928 price. For this weight class of steers sold by cooperatives the average price in 1929 was $\$ 1.62$ below the average price for 1928, while the average price paid by inclependent dealers in 1929 for this weight of steers was only 6 cents per cwt. below the average price paid in 1928.

Chart 6, constructed from data given in Table 58, shows the changes in the average monthly price of good steers weighing 950 to 1100 pounds on the Pittsburgh market, compared with the changes in the average price for the year received through cooperative sales, and changes in the average price paid by independent dealers.

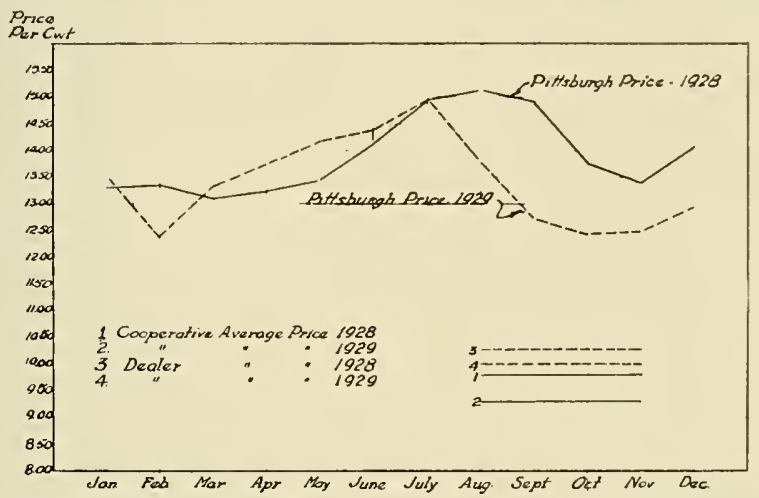

CHART 6-The monthly average price of good steers weighing 950 to 1100 poumds on the Pittshurgh market, the average home price receiced by patrons of cooperative associations, and the average price paid by dealers for steers of this weight class, 1928 and 1929

For good steers weighing 950 to 1100 pounds on the Pittsburgh market, the August 1929 average price was $\$ 1.26$ per cut. below the August 1928 price; the September 1929 price was $\$ 2.28$ below the September 1928 price; and the October 1929 price was $\$ 1.20$ below the 1928 price. The average price for this weight class of steers received from sales through the cooperatives in 1929 was 48 cents lower than in 1928, but for those so $^{1} d$ to dealers the average price was 29 cents per cwt. higher in 1929 than in 1928.

Table 58 shows that for medium steers weighing 850 pounds and up on the Pittsburgh market, the August 1929 price was 72 cents per cwt. below the August 1928 price; the September 1929 price was $\$ 2.15$ below the September 1928 price; and the October 1929 price was $\$ 2$ below the October 1928 price.

For common steers weighing 850 pounds and up on the Pitsburgh market, the August 1929 price was 80 cents per cwt. below the August 1928 price; the September 1929 price was $\$ 1.19$ below the September 1928 price; and the October 1929 price was 95 cents below the October 1928 price. 
For steers weighing 550 pounds to 899 pounds the average price received by cooperatives was 86 cents per cwt. lower in 1929 than in 1928 , but the average price received for such steers sold to independent buyers was only 31 cents lower in 1929 than in 1928.

These comparisons are sufficient to show that the price of steers which were sold through cooperatives followed the changes in market price more closely than did the price of steers handled isy independent dealers. This is offered in proof of an earlier statement (page 11) that the contract system of buying livestock in West Virginia is hazardous to the independent dealer and is considerable of a gamble. This circumstance makes adequate price comparisons over a short period of time difficult. If the market price of livestock is high one year the private dealer is likely to offer a higher contract price for cattle the next year. He contracts cattle for the year ahead on the basis of the present year's market price. Under this system, if cattle prices are rising, the producer receives too little for them, but if the market prices are lower the next year the farmer profits by the contract provided the private dealer is able and willing to carry out his contract. In too many cases he is not able or willing to carry out the provisions of his contract during a falling market and the seller is left to dispose of his cattle as best he can, and often at a lower price than if he had been free to sell earlier in the season.

\section{Summary and Conclusions}

The best standard for measuring the efficiency of a private business is the rate of net profit it earns on its capital investment. For the independent dealer in livestock, net profit earned is likewise the best test of his efficiency. The net profit test, however, is not applicable to cooperative shipping associations because they operate as non-profit business enterprises, serving their patrons at actual cost of operation. There is no single standard so adequate for testing the efficiency of a shipping association as is the net profit measure for private business. It is necessary therefore to employ several standards, some of them rather intangible, in testing the efficiency of a cooperative business.

The central purpose of the cooperative associations is to assist the producers in obtaining the greatest possible net return on their livestock enterprises, in so far as marketing affects it. In addition to the individual management of the enterprise, the net return of those patronizing the shipping association is affected by the marketing cost, service, and terminal market price. The net return of those producers who do not patronize the shipping association is affected through its influence on the competing marketing agencies. In measuring the efficiency of a shipping association it is therefore necessary to inquire into costs, services, terminal market prices, and the activities of competitors. 
If the marketing service and terminal sales price are equal for both agencies, a cooperative shipping association is more efficient than its competitors if its marketing costs are lower. But a cooperative may operate at a lower cost than its competitors and yet be inefficient if the latter are operating on a high-cost basis. It has not reached its full degree of efficiency until it operates at the minimum cost possible for it to attain under conditions which it cannot further modify. In evaluating the efficiency of such business enterprises it is necessary to analyze their costs and form some judgment of their approach to the possible minimum.

An analysis of the marketing costs of the cooperative livestock shipping associations in West Virginia leads to the conclusion that they are higher than the minimum costs necessary for maximum efficiency and probably higher than those of many competing dealers. The excess of costs above the efficient minimum was due to a combination of small volume of business and poor management while attempting to give adequate marketing service. It appears impossible to apportion the excess in costs to each of these factors.

\section{Transportation Costs}

Small volume of business was a factor in increasing the transportation costs above the possible minimum. The minimum transportation cost in this state is procured by sending livestock to market by railroad in straight carloads, loaded to the minimum weight fixed by the railroads. In the case of sheep and lambs the minimum rate is procured only by shipment in double-decks. It is possible to load calves with cattle in such a way as to cause no increase in the rate.

This study reveals that most of the cooperative associations transported their cattle at the minimum rate, but that the cost of transporting their sheep, lambs, and calves was considerably in excess of the minimum. A large proportion of the shipments were of mixed carloads, single-decks, and below the minimum weight. One association transported all and another a part of its livestock by truck, thus increasing their costs greatly above the minimum rate by railroads.

There is some evidence to indicate that a part of the excess transportation cost was due to poor management in making up the shipments, but the larger part appears to have been due to small vo! ume coupled with the attempt to make frequent shipments. Of course, the small volume may be attributed to some extent to poor management.

\section{Yardage Costs}

Since yardage rates were based on the head, neither the number of animals in a car nor the weight of the load had any effect on the total yardage costs, except in the case of the Baltimore market, where 
there was a maximum yardage charge per car. This maximum charge is reached by shipping full-loaded cars, and only by a greatly overloaded car may the rate be reduced below the rate on the head basis. Neither management nor volume of business had any appreciable effect on this item of cost.

\section{Selling Commission Costs}

With the exception of the Pittsburgh market, where a maximum selling charge per car obtained, the selling commission cost was not affected by the number of anima's, weight of load, or kind of shipment. In the case of this market it was not possible to secure the minimum rates except in a straight-shipment, full-loaded car. In many instances mixed shipments increased the selling cost by $\$ 3$ per car, and truck shipments increased the rate on lambs 150 percent above the minimum on a double-deck carload. For most of the associations that shipped to the Pittsburgh market the selling cost was higher than the mininum cost. This was due to small volume and poor management.

\section{Local Car Expense}

The items making up the cost which is called local car expense were not uniform for all associations. For the most part local car expense consisted of costs for partitions, bedding, rope, telephone and telegraph charges, etc. In so far as the expense was composed of costs arising from mixed shipments, it $\mathrm{a}^{1}$ so was increased because of small volume and poor management. A part of the local car expenses is necessary regardless of the volume of business.

\section{Manager's Commission}

The manager's commission was paid on the hundredweight basis. This item of cost is not affected by volume except that it might be reduced if there were a sufficient volume to give the manager a satisfactory total return at a lower rate of commission.

\section{Insurance Fund}

The insurance fund charges were paid on the hundredweight basis and hence were not immediately affected by the volume of business. The association expenses and losses are paid out of this fund. Expenses and losses do not increase in direct proportion to the volume of business. Hence an increase in the volume of business would permit either a reduction in this charge or an increase in the amount of patronage dividends.

\section{\%. Losses from Death and Injury}

Losses from death and injury did not constitute a separate item of cost but were paid out of the insurance fund collections. Anything contributing to such losses therefore prevents a reduction in the insurance fund costs. Data on losses from death and injury were not procured for the West Virginia associations, but a study in the neighboring state of Ohio indicates that such losses are greater in single-decks and mixed shipments. Since a large proportion of the 
shipments of the West Virginia cooperatives was in single-deck or mixed shipments, it is probable that the losses were larger than they would have been had there been sufficient volume to permit doubledeck, straight shipments.

There is no tangible evidence to show that the marketing costs of the cooperative shipping associations in West Virginia were higher than those of their independent competitors, but the independent dealer operates in such a manner that good management on his part would result in minimum marketing costs. He has control of the livestock which he ships and can call for the delivery of a sufficient number of animals to permit loading in such a way as to result in minimum costs all along the line.

It seems reasonable to conclude that the marketing costs of the shipping associations in West Virginia were greater than they should be for maximum efficiency. The question arises as to the possibility on the part of the associations of lowering these costs. The key to lowering the marketing costs is larger volume and better management.

The ultimate volume for the cooperatives is limited by the comparatively small production in the state, while the potential volume is limited by the activities of the competing independent dealers. It is beyond the province of shipping associations to attempt anything more than minor adjustments in the volume of production. It is, however, clearly within their province to attempt to secure a sufficient share of the production to give them a volume which will permit efficient operation.

\section{MARKETING SERVICE AS A FACTOR IN MEASURING EFFICIENCY}

If marketing costs and terminal sales prices are equal for both agencies, the cooperative is more efficient than its competing independent dealers if it renders a more adequate marketing service. But, as in the case of marketing cost, a comparison with the services rendered by competitors is not a sufficient measure of efficiency because the competitors may be giving a low order of service. It therefore becomes necessary to analyze the service given by the cooperative and to form some judgment of its adequacy and economy.

One of the strong arguments favoring the cooperative marketing of livestock is that the producer does not have to put all of his animals on the market at one time. If he has to do this he takes a chance on hitting a temporarily unfavorable market and he also may have to market some animals that are not in condition to bring the best returns. If the cooperative is to render this kind of service it means that it must make shipments at frequent intervals during the marketing season. Some of the cooperatives in West Virginia have given adequate service in this respect; others have not. The asso- 
ciation which ships only two or three carloads of livestock during the season can hardly be considered efficient in respect to this kind of service. In attempting to give adequate service many associations have increased their marketing costs.

A common objection to cooperative marketing is that the patron is responsible for the delivery of his animals to the shipping point, while the independent dealer takes possession of them at the farm. This was not a serious objection as long as animals could be driven to the shipping point, since this involved little expense and trouble. But with the extensive construction of hard-surfaced roads, driving animals to the shipping point has become almost impossib!e. Few farmers own trucks and therefore most are required to hire trucks for hauling their livestock. The independent dealer often has his own truck and can collect the animals directly from the farm. The cooperative associations in West Virginia are deficient in this kind of service. It seems probable that they will have to provide such service if they are to compete successfully with the independent dealer.

The independent dealers are providing a financing service for the producers, a part of which appears to be beyond the province of cooperative associations. This financing service takes two forms: financing the feeding operations, and making loans in the form of advance payments on animals. The first of these is accomplished through the practice of "letting out" livestock for feeding or grazing, in which case the farmer has no capital invested in the animals. It now seems possible for the cooperatives to provide some such financing service as this through the facilities offered by the Federal Farm Board. The independent dealer financing which consists of making loans to small producers appears to have no place in a cooperative shipping association. This is a valuable service in the giving of which the independent dealer appears to hold a superior position.

The cooperative association pays the producer on the basis of the terminal market price. In so far as quality is a factor in the terminal market price it is reflected in the returns to the producer. The independent dealer does not provide such service.

When a producer ships livestock through a cooperative association he is reasonably sure that he will be paid for them. He cannot be so certain of receiving pay from the independent dealer. There are many instances in West Virginia of broken contracts and of payments by check without sufficient funds.

In some respects the marketing services offered by the independent dealers in West Virginia appear to be superior to those offered by the cooperative shipping associations, but in other respects the reverse is true. A larger volume of business would permit the cooperatives to improve their services materially. 
If marketing cost and service are equal for both agencies, the cooperative shipping association is more efficient than its inclependent dealer competitors, if for the same quality of livestock its terminal market price is consistently higher, or if the cooperative is instrumental in improving the quality of livestock so that it commands a higher price. But again a mere comparison of the terminal market prices is not an adequate test of efficiency, since the competing dealers may be receiving lower terminal market prices than are justified by the quality of the animals sold. In dealing with this measure of efficiency it is necessary to analyze those factors responsible for terminal market price over which the cooperative shipping association has some control, and to form some judgment of its efficiency in dealing with them.

The terminal market sales price depends on three sets of factors: the conditions of supply and demand, the ability of the selling agent, and the quality of the animals. The cooperative shipping association in West Virginia can have little effect on the conditions of supply and demand. The total livestock production of the state comprises a small part of the total sales on the markets where West Virginia livestock is sold. It is, however, sometimes possible upon the advice of well-informed commission merchants to withhold shipments from a glutted market or to rush them into an undersupplied market. West Virginia cooperative shipping associations are hampered in this respect because their shipments are made up of small lots from many farms and it is difficult to make hurried changes in shipping dates. About the best the cooperative can do is to attempt to make regular shipments. The independent dealer is in a better position to take advantage of the fluctuations in the supp ${ }^{1}$ ies on the market. He has considerable leeway in time in which to take up his livestock and he can ship or hold till a later date as his judgment directs him.

The ability of the commission merchant has some effect on the terminal market price. The manager of the cooperative association is responsible for choosing the commission agent to sell the livestock. Evaluating the ability of the commission merchants on the markets patronized by West Virginia cooperative shipping associations is beyond the scope of this study. Suffice it to say that on the Pittsburgh market the associations sell through a cooperative commission firm, of which they are members. On the other markets the cooperatives sell through the same commission firms that the independent dealers patronize. There are several commission merchants on these markets and any selling advantage which the cooperative might have over an independent dealer would be the result of a wise choice of commission firm to do the selling. Many advantages are claimed for the cooperative commission firm. If there are advantages in 
selling through such an agency then the cooperatives are losing those advantages by selling through independent commission dealers.

In so far as the terminal market price is the result of the quality of animals sold, it appears as though the cooperatives in West Virginia have done much toward securing a higher terminal market price for their patrons. The improvement in quality has come about through the efforts of agencies working with the shipping associations, but without the cooperatives' paying for livestock on a quality basis it is doubtful if any great success would have attended the efforts of the other agencies.

The cooperative has an incentive to improve the quality, for with costs as they are the price received by the producer is dependent upon the terminal market price. On the other hand the independent dealer has little incentive to encourage improvement in quality. His profit depends on the difference between his selling price and buying price plus expenses. If his terminal market price is low he cannot pay so much for the livestock as if the terminal price were higher, but this need not affect his profit. In fact purchasing animals on a quality basis is a distinct source of trouble and extra expense to the independent dealer.

The work of the cooperatives in the improvement of the quality of livestock in West Virginia is probably their greatest achievement. Yet the work, just begun, cannot become fully effective until a larger part of the producers patronize those associations which pay according to quality.

\section{THE EFFECT OF COOPERATIVE ASSOCIATIONS ON THE ACTIVITIES OF THEIR COMPETITORS AS A MEASURE OF EFFICIENCY}

If a cooperative association is instrumental in raising the plane of competition it may be considered to have elements of efficiency. The effects of a cooperative on the activities of its competitors are most difficult to measure. It may result in decreased margins and improved service on the part of the independent dealers so that producers who sell to them receive just as good or better service and prices as those who patronize the cooperative. If it is shown that the cooperative service is adequate and that their costs are near the minimum, then, if the independent dealers are paying prices equal to or better than the cooperative price, it must be concluded that they are operating on a very narrow margin or perhaps taking losses.

Data presented in the body of this report are not sufficient for a conclusive statement on prices received from the two agencies but they indicate that in 1928 dealers paid about as much as farmers received through the cooperative and in 1929 paid a higher price than the cooperative price.

Many of the dealers are speculators and hence a part of the price paid was speculative. In periods of rising prices there is also more competition between independent dealers. It seems improbable that independent dealers can continue to pay prices higher than the co- 
operative price. Many of them lost heavily on their speculative buying of 1929 and some have had to give up their buying operations because of depleted capital.

The mere fact that a farmer can sell through a cooperative association if he chooses gives him an advantage in bargaining and has some weight in forcing the dealer to pay a price equal to the cooperative price. Cooperatives may be quickly organized or revived and in a state that has had experience with them the mere threat of an active association has an influence on the prices paid by the independent dealer. More and more the farmers are gretting away from the practice of selling their livestock on contract, and inclependent dealers are finding it more difficult to buy livestock for less than the cooperative price. The bitter opposition of the independent dealers to the cooperatives is excellent proof that they are feeling the competition.

The cooperative shipping associations in West Virginia can become more effective in raising the plane of competition if they can increase their volume of business and secure better management so that costs may be reduced and service improved.

\section{Bibliography*}

AsHBy, R. C. LIVESTOCK TRUCKAgE RATES IN ILLINOIS, WITI A COMPARISON OF mafieting expense by truck and Rail. Ill. Agr. Exp. Sta. Bul. 324, 1930.

Burmeister, C. A., Conway, H. M., and Brodell, A. P. economic factors afFecting the BeEF-Ca'tTle industry of virginia. U. S. Dept. of Agi'. Technical Bul. 237, 1931.

Doty, S. W. cooperative livestock silipping associations. U. S. Dept. of Agr. Farmers' Bul. 718, 1916.

marketing Livestock in the south. U. S. Dept. of Agr. Farmers' Bul. 809, 1917.

Durand, E. D. COOPERATIVE Livestoci shipping associations in minnesota. Minn. Agr. Exp. Sta. Bul. 156, 1916.

(1) Fitzgerald, D. A. local cooperative livestock marketing associations in IOWA Since 1920. Iowa Agr. Exp. Sta. Bul. 254, 1928.

(2) Gaumnitz, E. W., and Black, J. D. organization and management of local livestock shipping associations in minnesota. Minn. Agr. Exp. Sta. Bul. 201, 1922.

Hedges, Harold, and Filley, H. C. cooperative marketing of livestock in Nebraska. Neb. Agr. Exp. Sta. Bul. 209, 1925.

(3) Henning, G. F. Losses in shipping oilo Livestock. Ohio Agr. Exp. Sta. Bul. 438, 1929.

MARKET Movements of Livestock in OIIIO. Ohio Agr. Exp. Sta. Bul. $409,1927$.

* Only citations referred to in text are numbered. 
(4) THE TRTCK AND ITS RELATIONSHIP TO LIVESTOCK MARKETING IN онго. Ohio Agr. Exp. Sta. Bul. 440, 1929.

(5 ) Hibbard, B. H., Foster, L. G., and Davis, D. G. wisconsin Livestock shipPing associations. Wis. Agr. Exp. Sta. Bul. 314, 1920.

Jesness, O. B. cooperative livestock shipping associations. Ky. Agr. Ext. Div. Cire. 104, 1921.

Joinson, E. C. marketing Kentucky livestock. Ky. Agt. Exp. Sta. Bul. 278, 1927.

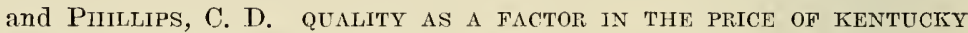
LAMBs. Ky. Agr. Exp. Sta. Bul. 302, 1930.

LOOMIS, RALPH. COOPERATIVE LIVESTOCK SHIPPING ASSOCIATIONS IN Missourt. Mo. Agr. Exp. Sta. Bul. 199, 1923.

(6) Macklin, Theodore, and Schants, M. A. Marketing livestock cooperativeLY. Wis. Agr. Exp. Sta. Bul. 381, 1926.

Miller, P. L. DIRECT PACKER BUYing in THE MARKETING OF LIVESTOCK. Jour. Farm Econ. XI, no. 2, April, 1929.

Nourse, E. G., and Hammans, C. W. COOPERAtive LIVESTOCK SHipping in IOWA IN 1920. Iowa Agr. Exp. Sta. Bul. 200, 1921.

and Knapp, J. G. The cooperative marketing of Livestock. Published by The Brookings Institution, Washington, D. C., 1931.

Plumb, C. S. marketing Livestock. U. S. Dept. of Agr. Farmers' Bul. 184, 1903.

( 7 ) Reid, T. R. cooperative silipping of Livestock. Ark. Agr. Ext. Div. Circ. $102,1921$.

( 8 ) Thomsen, F. L., and Thorne, G. B. COOperative marketing for missouri. Mo. Agr. Exp. Sta. Bul. 253, 1927.

(9) Wallace, B. A. Cooperative livestoch marketing in ohio. Ohio Agr. Exp. Sta. Bul. 375, 1924.

(10) Wiley, James R. MOTOR tRANSPORTATION OF HOGS to TIIE INDIANAPOLIS MARKet. Ind. Agr. Exp. Sta. Bul. 337, 1930.

Death and CRIPPle losses in shipping hogs to market. Ind. Agr. Exp. Sta. Bul. 318, 1927.

Cooperative livestock shipping associations. U. S. Dept. of Agr. Farmers' Bul. $718,1916$.

Livestock and wool marketing. American Cooperation, vol. II, 1927. Published by The American Institute of Cooperation.

(11) MinNesota FARM BUSINESs NOTEs, no. 95, Oct. 20, 1930.

ORGANIZATION AND MANAGEMENT OF COOPERATIVE LIVESTOCK SHIPPING ASSOCIATIONS. U. S. Dept. of Agr. Farmers' Bul. 1292, 1923. 

